ISSN (print) $0867-2008 /$ ISSN (online) 239 I-7512

DOI: http://dx.doi.org/10.12775/OM.2017.007

\title{
GRZEGORZ ŻABIŃSKI
}

Instytut Historii

Akademia im. Jana Długosza w Częstochowie

Al. Armii Krajowej 36a

42-200 Częstochowa

Poland

g.zabinski@gmail.com

\section{NOT ONLY BARRELS - EQUIPMENT FOR FIREARMS IN THE STATE OF THE TEUTONIC ORDER IN PRUSSIA}

\section{KEYWORDS}

Firearms equipment; projectiles; gunpowder; Late Medieval Prussia; Teutonic Order; Middle Ages

\section{INTRODUCTION}

7 he history of research on firearms in the state of the Teutonic Order in Prussia (fig. I) is already about i 50 years long. One of the first works was

a paper by M. Toeppen ${ }^{1}$, worth mentioning are also works by M. Baltzer ${ }^{2}$,

I M. Toeppen, Die älteste Nachrichten uber das Geschützwesen in Preussen, Archiv für Offiziere des Königlichen Preussischen Artillerie- und Ingenieure Corps 63 (1868), pp. I23-I68, 2 I I$-236$.

2 M. Baltzer, Zur Geschichte des Danziger Kriegswesens im 14. und Is. Jahrhundert. Ein Beitrag zur Säcularfeier der Vereinigung Danzigs mit der preussischen Monarchie, Wissenschaftliche Beilage zum Programm des Königlichen Gymnasiums zu Danzig, Danzig I 893. 
B. Engel ${ }^{3}$, extensive and to some degree still valid publications by B. Rathgen ${ }^{4}$, papers by M. Grodzickas, or a book by V. Schmitdchen. ${ }^{6}$ The latter was intended to comprehensively discuss the problem of firearms in the Order's state in the period to i 4i o. Of great value are also works by A. Nowakowski', M. Woźniak ${ }^{8}$, M. Arszyński and I. Sikorska-Ulfik ${ }^{9}$, W. Świętosławski ${ }^{10}$, A. R. Chodyński ${ }^{11}$,

3 B. Engel, Nachrichten über Waffen aus dem Tresslerbuche des Deutschen Ordens von 1399-1409, Zeitschrift für Historische Waffenkunde I (1897-1899), pp. 195-199, 228-233; idem, Waffengeschichte-Studien aus dem Deutschordensgebiet, Zeitschrift für Historische Waffen- und Kostümkunde 4 (1906-1908), pp. I 1 8-125.

4 B. Rathgen, Die Pulverwaffe im Deutschordensstaate von ${ }_{3} 62$ bis 1450 , Elbinger Jahrbuch 2 (1922), pp. I- I 16; idem, Die Faule Grete, Elbinger Jahrbuch 4 (1924), pp. 45-76; idem, Das Geschütz im Mittelalter, Berlin 1928.

5 M. Grodzicka, Zabytkowe dziata spiżowe w zbiorach polskich, Studia i Materiały do Historii Wojskowości 6 (1960), 2, pp. 358-41 5; eadem, Bombarda z zamku w Kurzętniku (Najstarszy spiżowy okaz artylerii krzyżackiej), Studia do Dziejów Dawnego Uzbrojenia i Ubioru Wojskowego I (1963), pp. 7-1 3 .

6 V. Schmidtchen, Die Feuerwaffen des Deutschen Ritterordens bis zur Schlacht bei Tannenberg I4IO: Bestände, Funktion und Kosten, dargestellt anhand der Wirtschaftsbücher des Ordens von 1374 bis 1410 , Lüneburg 1977.

7 A. Nowakowski, Some Remarks about Weapons stored in the Arsenals of the Teutonic Order's Castles in Prussia by the End of the $14^{\text {th }}$ and early $15^{\text {th }}$ Centuries, in: Das Kriegswesen der Ritterorden im Mittelalter, ed. Z. H. Nowak (Ordines Militares. Colloquia Historica Torunensia VI), Toruń I 99 I, 75-88; idem, Źródta zaopatrzenia w uzbrojenie wojsk krzyżackich w Prusach $w X I V-X V w$., in: Pamiętnik XIV Powszechnego Zjazdu Historyków Polskich, ed. D. Bednarska-Pituła, 2 vols, here vol. 2, pp. 333-337, Torun 1 994; idem, Arms and Armour in the Medieval Teutonic Order's State in Prussia (Studies in the History of Ancient and Medieval Art of Warfare 2), Łódź 1994; idem, Arsenat zamku krzyżackiego w Toruniu, in: Materiaty z VII sesji naukowej Uniwersyteckiego Centrum Archeologii Średniowiecza i Nowożytności, ed. J. Olczak (Archaeologia Historica Polona I 4), pp. 223-23 I, Toruń 2004.

8 M. Woźniak, II. 2. 23. Bombarde, in: 800 Jahre Deutscher Orden. Ausstellung des Germanischen Germanisches Nationalmuseums Nürnberg in Zusammenarbeit mit der Internationalen Historischen Kommission zur Erforschung des Deutschen Ordens, hrsg. v. U. Arnold, G. Bott, Gütersloh-München I 990, p. 70,

9 M. Arszyński, I. Sikorska-Ulfik, II. 2. 24. Büchsenkugeln, in: 80o Jahre Deutscher Orden (as n. 8), pp. 70-7I.

10 W. Świętosławski, Koszt broni palnej i jej użycia w państwie krzyżackim w Prusach na początku $X V$ wieku, Studia i materiały do historii wojskowości 35 (1993), pp. 19-3 I.

${ }_{11}$ A. R. Chodyński, Zbrojownie malborskie, Malbork 1978; idem, Habsburg artillery at the close of the $15^{\text {th }}$ and the beginning of the $16^{\text {th }}$ centuries, Fasciculi Archaeologiae Historicae 9 (1996), pp. 5 I-59; idem, The stores of arms in the town hall of Elblag at the beginning of the $15^{\text {th }}$ century, Fasciculi Archaeologiae Historicae 9 (1996), pp. I 5-24; idem, Inwentarz broni palnej w ratuszu elblaskim z 1413 roku, Rocznik Elbląski is (1997), pp. 69-79; idem, Bombarda krzyżacka $z$ Kurzętnika, in: Imagines potestatis. Insygnia i znaki wtadzy w Królestwie Polskim i Zakonie Niemieckim. Katalog wystawy w Muzeum Zamkowym w Malborku 8 czerwca - 30 września 2007 roku, ed. J. Trupinda, Malbork 2007, pp. 388-389; idem, I.9.2. Bombarda krzyżacka 
B. Możejko ${ }^{12}$, P. Strzyż $\dot{1}^{13}$, S. Jóźwiak and J. Trupinda ${ }^{14}$, or M. Dąbrowska ${ }^{15}$. An extensive and enormously valuable popular-scientific book on the military of the Teutonic Order in Prussia has been recently been published by K. Kwiatkowski. ${ }^{16}$ This work also contains numerous valuable observations concerning firearms. Some remarks on firearms in the Order's state were also made by the author of the present paper $^{17}$, in some cases with co-authorship of other scholars. ${ }^{18}$ Numerous interesting pieces of information can also be retrieved from publications dealing

$z$ Kurzętnika, pocz. $X V$ w., in: Fundacje artystyczne na terenie państwa krzyżackiego w Prusach. Katalog wystawy w Muzeum Zamkowym w Malborku 25 czerwca - I2 września 2010 roku, ed. B. Pospieszna, 2 vols, here vol. I, Malbork 20 I o, pp. I 26-I 27; idem, Magazyny broni na zamku w Malborku wśredniowieczu i w czasach nowożytnych. Muzealne zbiory militariów w XIX i XXw., in: Materiaty z sesji naukowej z okazji 6olecia Muzeum Zamkowego w Pszczynie, II-I2 maja 2006 r., ed. M. Kluss, Pszczyna 20 io, pp. I 8 I-200.

I2 B. Możejko, Ikonograficzne źródto do historii artylerii w drugiej potowie XV wieku, Kwartalnik Historii Kultury Materialnej 48 (2000), 3-4, pp. 17 I-1 76.

13 P. Strzyż, Zespót kamiennych kul dziatowych z zamku $w$ Reszlu, Komunikaty MazurskoWarmińskie 4/258 (2007), pp. 46I-470; see also P. Strzyż, P. Czubla, A. Mackiewicz, Cannonballs from the Olsztyn turret, Fasciculi Archaeologiae Historicae 28 (2015) (From the Problems of Historical Archaeology), pp. I 23- 13 I.

14 S. Jóźwiak, J. Trupinda, Organizacja życia na zamku krzyżackim w Malborku w czasach wielkich mistrzów (1300-1457), Malbork 2007.

is M. Dąbrowska, Proces odlewania dziat w lejni malborskiej w XV wieku, Archaeologia Historica Polona 8 (2009), pp. 2 I-44; eadem, Badania archeologiczno-architektoniczne na terenie Zamku Niskiego w Malborku w latach 1998-2004, in: XV Sesja Pomorzoznawcza. Materiaty z konferencji 30 listopada - 2 grudnia 2005 r., ed. G. Nawrolska, Elbląg 2007, pp. 303-3 16.

${ }^{16}$ K. Kwiatkowski, Wojska Zakonu Niemieckiego w Prusach I230-I525. Korporacje, jej pruskie wtadztwo, zbrojni, kultura wojny i aktywność militarna (Dzieje Zakonu Niemieckiego 3), Toruń 2016.

17 G. Żabiński, Das Marienburger Ämterbuch as a source for the Teutonic Order's arms and armour resources, in: Non sensistis gladios. Studia ofiarowane Marianowi Gtoskowi w 7o. rocznice urodzin, ed. O. Ławrynowicz, J. Maik, P. A. Nowakowski, Łódź 20 I I, pp. 505-5 I 4; idem, The Grose bochse - a Teutonic Supergun from 1408, Fasciculi Archaeologiae Historicae 25 (2012), pp. 3 I-40; idem, Das Grosse Ämterbuch des Deutschen Ordens - remarks on its value for arms and armour research, in: Weapons Bring Peace? Warfare in Medieval and Early Modern Europe, ed. Lech Marek (Wratislavia Antiqua I 8), Wrocław 201 3, pp. I 99-2 I 2; idem, Ways of acquisition of firearms and related equipment in the state of the Teutonic Order in Prussia, Acta Militaria Mediaevalia Io (2014), pp. I I9- I 42; idem, Technology of manufacture of firearms in the Teutonic Order's state in Prussia - gun barrels and metal projectiles, Fasciculi Archaeologiae Historicae 28 (2015), pp. 83-1 10.

18 G. Żabiński, P. Muntowski, Średniowieczne i wczesnonowożytne militaria z watu von Plauena na Zamku w Malborku, in: XVIII Sesja Pomorzoznawcza, 2 vols, ed. E. Fudzińska, here vol. 2: Od późnego średniowiecza do czasów nowożytnych. Materiaty z konferencji I 6-I 8 listopada 20II, Malbork 201 3, pp. 37-58; J. Stępiński, G. Żabiński, P. Strzyż, The light field cannon from Kurzętnik - a unique example of medieval artillery (against the background of development of firearms in the Teutonic Order's state in Prussia), Acta Militaria Mediaevalia 9 (2013), pp. I 55-202. 
with firearms in what is now Poland and in Central Europe. ${ }^{19}$ Of enormous value are two books by P. Strzy $\dot{z}^{20}$, which are based on a very broad assemblage of archaeological finds and also make some use of Teutonic written sources.

In spite of the fact that equipment accompanying firearms has also been dealt with in many of these works, it seems that our state of knowledge on this issue is still far from perfect. An attempt at partially filling this gap has already been undertaken by the author, with support from J. Stępiński and P. Strzyż. ${ }^{21}$ Although the main focus of the paper was to discuss the technology of the cannon from Kurzętnik (Germ. Kauernick) ${ }^{22}$, it was also attempted at offering some remarks on the firearms' equipment.

Concerning the source basis, the most significant are these which are directly related to the Teutonic Order itself. Of enormous importance is the account book of the Order's Treasurer ${ }^{23}$, which covers the years I 399-I 409. Relevant pieces of information can also be extracted from the book of the Marienburg (Pol. Malbork) Convent ${ }^{24}$, which records expenses for the years I399-I 4 I 2. Numerous expenses on equipment for firearms can be found in the expense book of the House Commander of Marienburg 25 for the years I410-1420. A great deal of data is available from the Order's inventories and visitation reports. ${ }^{26}$ The nature

19 See e.g. K. Konieczny, Ręczna broń palna w Polsce $w X V$ i XVI w., Muzealnictwo Wojskowe 2 (1964), pp. 167-237; M. Głosek, Brońpalna, in: Uzbrojenie w Polsceśredniowiecznej 1350-145o, ed. A. Nadolski, Łódź 1990, pp. 155-164; M. Mielczarek, Ręczna broń palna, in: Uzbrojenie $w$ Polsce średniowiecznej I450-I500, ed. A. Nowakowski, Toruń 1998, pp. 60-64; idem, Artyleria, in: Uzbrojenie w Polsce średniowiecznej I450-I50o (as above), pp. 65-72; J. Szymczak, Początki broni palnej w Polsce 1383-1533, Łódź 2004; L. Klimek, J. Stępiński, P. Strzyż, G. Żabiński, Late medieval wrought iron firearms from the Museum in Biecz, Fasciculi Archaeologiae Historicae 26 (2013), pp. 83-98.

20 P. Strzyż, Średniowieczna broń palna $w$ Polsce. Studium archeologiczne, Łódź 20 I I; idem, Broń palna w Europie Środkowej $w X I V-X V w$., Łódź 2014.

${ }_{21}$ Stępiński, Żabiński, Strzyż (as n. I 8).

22 In this paper historical local names from the 14 th-16th centuries are used first, while later names are given in parentheses, therefore e.g.: Danzig (Pol. Gdańsk), and Marienburg (Pol. Malbork).

23 Das Marienburger Tresslerbuch der Jahre 1399-I409 (henceforth: MTB), ed. E. Joachim, Königsberg I 896.

24 Das Marienburger Konventsbuch der Jahre 1399-14I2 (henceforth: MKB), ed. W. Ziesemer, Danzig I9r 3.

25 Das Ausgabebuch des Marienburger Hauskomturs I4IO-I420 (henceforth: ABMH), ed. W. Ziesemer, Königsberg I 9 I I.

26 Visitationen im Deutschen Orden im Mittelalter, Part I (I236-I449) (henceforth: Visitationen I), ed. M. Biskup, I. Janosz-Biskupowa, red. U. Arnold (Quellen und Studien zur Geschichte des Deutschen Ordens 50, I), Marburg 2002; Visitationen im Deutschen Orden im Mittelalter, Part 2 (I450-1519) (henceforth: Visitationen 2), ed. M. Biskup, I. Janosz-Biskupowa, red. U. Arnold 
and value of these sources have recently been discussed. ${ }^{27}$ Furthermore, numerous significant pieces of information are contained in an anonymous register of the Order's firearms and related equipment from c. $1523 .{ }^{28}$ The researcher's situation, on the other hand, is much worse with regard to firearms in Prussian towns. One of the most important sources are the account books of the Old Town of Elbing (Pol. Elbląg) ${ }^{29}$ and of Thorn (Pol. Toruń) ${ }^{30}$. Accounts produced for the needs of the Prussian Confederacy during the Thirteen Years War ( I 454-I 466) against the Order are also of use..$^{31}$ Apart from that, in some cases it is possible to find relevant data in narrative sources, for instance the Ältere Hochmeisterchronik ${ }^{32}$, the Jüngere Hochmeisterchronik ${ }^{33}$, the Preussische Chronik of Simon Grunau ${ }^{34}$, the continuation of the chronicle of Johann von Posilge ${ }^{35}$, the Hanseatische Chronik of Bernt

(Quellen und Studien zur Geschichte des Deutschen Ordens 50,2), Marburg 2004; Das grosse Ämterbuch des Deutschen Ordens (henceforth: GÄDO), ed. W. Ziesemer, Danzig I 92 I; Das Marienburger Ämterbuch (1375-1442) (henceforth: MÄB), ed. W. Ziesemer, Danzig 1916.

27 See e.g. Żabiński, Das Marienburger Ämterbuch (as n. 17); idem, Das Grosse Ämterbuch (as n. I7); Stępiński, Żabiński, Strzyż (as n. I 8), pp. I 64-165.

28 M. Biskup, Wykaz sprzętu artyleryjskiego Zakonu Krzyżackiego w Prusach z okoto I 523 roku, Komunikaty Mazursko-Warmińskie I-2/167-168 (1984), pp. 97-103.

29 Nowa ksiega rachunkowa Starego Miasta Elblaga, Part I (1404-I4IO) (henceforth: NKRSME I), ed. M. Pelech (Towarzystwo Naukowe w Toruniu. Fontes 72), Warszawa I987; Part II (I4II-I4I4) (henceforth: NKRSME II), ed. M. Pelech (Towarzystwo Naukowe w Toruniu. Fontes 73), Warszawa 1989.

30 Ksiega kamlarii miasta Torunia z lat 1453-I495 / Kämmereibuch der Stadt Thorn von 1453 bis 1495 (henceforth: KKMT), ed. K. Kopiński, K. Mikulski, J. Tandecki (Źródła do dziejów średniowiecznego Torunia / Quellen zur Geschichte des mittelalterlichen Thorn 3), Toruń 2007.

31 Ksiega żotdu Zwiazku Pruskiego z okresu wojny trzynastoletniej 1454-1466 (henceforth: KŻZP), ed. A. Czacharowski (Towarzystwo Naukowe w Toruniu. Fontes 61), Toruń 1969; Ksiega Theudenkusa (henceforth: KT), ed. L. Koczy (Towarzystwo Naukowe w Toruniu. Fontes 33; Źródła do dziejów wojny trzynastoletniej I), Toruń 1937; M. Biskup, Wykaz broni palnej i innego sprzętu wojennego wysytanego przez Torun w okresie wojny trzynastoletniej (1454-1466), Zapiski Historyczne 3 I ( I 966), I, pp. 8 I -94.

32 Die Ältere Hochmeisterchronik, ed. M. Toeppen, in: Scriptores rerum Prussicarum. Die Geschichtsquellen der preussischer Vorzeit bis zum Untergange der Ordensherrschaft, 5 vols., ed. Th. Hirsch, M. Toeppen, E. Strehlke, Leipzig I 86 I- I 874, here vol. 3, pp. 5 I9-709.

33 Die Jüngere Hochmeisterchronik, ed. T. Hirsch, in: Scriptores rerum Prussicarum (as n. 32), vol. 5 , pp. I-I 72 .

34 S. Grunau, Preussische Chronik, vol. I, in: Die Preussischen Geschichtsschreiber des XVI. und XVII. Jahrhunderts, ed. M. Perlbach, 5 vols. Leipzig I 876-1998, here vol. I; vol. 2, ed. M. Perlbach, in: Die Preussischen Geschichtschreiber, vol. 2; vol. 3, ed. P. Wagner, in: Die Preussischen Geschichtschreiber, vol. 3.

35 Johanns von Posilge, Officials von Pomesanien, Chronik des Landes Preussen (von I360 an, fortgesetzt bis 1419) zugleich mit des auf Preussen bezuglichen Abschnitten aus der Chronik Detmar's von Lübeck, ed. E. Strehlke, in: Scriptores rerum Prussicarum (as n. 32), vol. 3, pp. I 3-399. 
Stegmann ${ }^{36}$, and others. ${ }^{37}$ Of certain value are also extracts of sources from the Ordensbriefarchiv. ${ }^{38}$

Concerning sources which can be use for comparative purposes, one must mention a series of Late Medieval and Early Modern Period treatises and manuals on firearms, such as the famous Bellifortis from c. I 405 by Konrad Kyeser ${ }^{39}$, a mid-I 5 th century work by Johannes Bengedans ${ }^{40}$, the Kriegsbuch by Ph. Mönch ${ }^{41}$ from I 496, the München copy of the Zeugbuch of the Roman King Maximilian I ${ }^{42}$ from c. I 502, Memoires d'artillerie by Surirey de Saint Remy ${ }^{43}$ from I 697, or Józef Jakubowski's Nauka Artyleryi (Teaching of Artillery) ${ }^{44}$, published in 178 I-I 783 .

The present paper is divided into the following sections:

- stocks, trestles, stands and carriages,

- gun instruments,

- tools for the manufacture of projectiles,

- equipment related to gunpowder,

- conclusions and suggestions for further research.

Eventually, some information should be offered about the monetary and weight system which existed in the Teutonic Order's state in Prussia in the discussed period. This data is given on the basis of sources and scholarship which

${ }^{6}$ [Bernt Stegmann's] Hanseatische Chronik, ed. T. Hirsch, in: Scriptores rerum Prussicarum (as n. 32), vol. 5, pp. $492-528$.

37 Geschichten von wegen eines Bundes von Landen und Steten wider den Orden unser Lieben Frawen und die Bruder desselben Ordens, ed. M. Toeppen, in: Scriptores rerum Prussicarum (as n. 32), vol. 4, pp. 71-211; Johann Lindaus Geschichte des dreizehnjaehrigen Krieges, ed. M. Toeppen, in: Scriptores rerum Prussicarum (as n. 32), vol. 4, pp. 490-675; Liborius Nakers Tagebuch über den Kriegszug des Hochmeisters Johann v. Tiefen gegen die Türken im J. 1497, ed. M. Toeppen, in: Scriptores rerum Prussicarum (as n. 32), vol. 5, pp. 289-3 I 4.

38 Regesta historico-diplomatica Ordinis S. Mariae Theutonicorum IIg8-1525, Pars I, 3 vols., ed. W. Hubatsch, E. Joachim, Göttingen 1950-1973, here vol. I (I198-1454), ed. W. Hubatsch; vol 3 (ISII-IS25), ed. W. Hubatsch.

39 Conrad Kyeser aus Eichstätt Bellifortis, c. I 405 (henceforth: Kyeser), ed. G. Quarg, Dusseldorf 1967.

40 Krigskunst og kanoner / Kriegskunst und Kanonen. Das Büchsenmeister-und Kriegsbuch des Johannes Bengedans (henceforth: Bengedans), ed. H. Blosen, A. R. Olsen, Aarhůs 2006.

${ }_{41}$ Ph. Mönch, Kriegsbuch, I 496, Universitätsbibliothek Heidelberg, Cod. Pal. Germ. I 26.

${ }_{42}$ Zeugbuch Kaiser Maximilians I, c. I 502, Innsbruck, Bayerische Staatsbibliothek München, Cod. Icon. 222.

43 S. de Saint Remy, Memoires d'artillerie. Recueillis par le Sr Surirey de Saint Remy, Commissaire Provincional de l'Artillerie, et l'un des Cent et un Officiers Privilegiez de ce Corps, Paris I 679.

44 J. Jakubowski, Nauka Artyleryi. Zebrana z naypóźnieyszych Autorów napisana dla pożytku korpusu Artyleryi narodowey z Rozkazu i Naktadem Jego Królewskiej Mci. Pana Naszego Mitościwego, Warszawa $178 \mathrm{I}-\mathrm{I} 783$. 
were consulted for the needs of this paper. Summarical data on this issue can also be found in several works of other authors. ${ }^{45}$

Currency:

I Mark -4 Ferto (Vierdung) -24 Scots -60 Schilling (shillings) -720 Denars

Weights:

I Last - I 2 Tonnen (barrels) - I 2 Schiffspfund (skippounds) - 36 Zentner - 240 Lispfund (lispounds) - 4320 Pfund (pounds)

I Stein (stone) - 34 Pfund in Gdańsk (Danzig) and Elbing (Elbląg), 24 Pfund in Toruń (Thorn)

I pound - c. $0.405 \mathrm{~kg}$

\section{STOCKS, TRESTLES, STANDS AND CARRIAGES}

In order to discuss the issue of stocks, stands and carriages for firearms in Teutonic Prussia, it seems prudent to offer a general overview of types of firearms which were used in the Order's state. It must be of course remembered that in many cases the terminology used in written sources is far from precise. ${ }^{46} \mathrm{~A}$ division into steynbuchsen (stone projectile guns) and lodbuchsen (lead bullet guns) can be roughly (but not always!) equivalent to artillery and hand-held firearms with very light cannons. However, it tells us nothing closer on construction details of firearms. Furthermore, such a division is of much less use at the turn of the i 5 th and i 6 th centuries, due to the spread of cast iron projectiles for artillery. ${ }^{47}$ It was therefore decided to disregard such mentions in written sources and focus on those from which more information can be gained. Concerning hand-held firearms, the most often used term was handbuchse. This term first appears in written sources in the early i 5 th century and is in use up to the end of the existence of the Order's state in Prussia. ${ }^{4}$ Weapons which can be interpreted as handbuchsen can be seen in

45 See e.g. Kwiatkowski (as n. I6), pp. I 42-1 43, Scheme I; p. 255, Scheme 4; Schmidtchen (as n. 6), 27; NKRSME I (as n. 29), p. xxxi.

46 See e.g. Szymczak (as n. 19), pp. 30-35.

47 Cf. Żabiński, Technology of manufacture, (as n. 17), p. 87.

${ }_{48} \mathrm{GÄDO}$ (as n. 26), pp. 60, 68-69, 70-71, 73-74, 87-88, 91, 97, I05-I06, I09-I I 0, I I 2-I I 4-II5, II7-II 8, I20, I22, I47-I48, I74-I75, I84-I85, I88, I89-I90, I98, I99-200, 207$-208,234,247,250-252,254,297,3$ I 4, 335, 339, 340, 348, 352, 358-359, 390-395, 48 I-482, 523, 549, 55 I-552, 554, 578, 6I6; MÄB (as n. 26), pp. I43-I44, I47-I 48; Visitationen I (as n. 26), No. 90, p. I I ; No. I 20, p. 250 ; No. I 23, p. 26 I-262; No. I 24, p. 276; No. I 34 , p. 322 ; Visitationen 2 (as n. 26), No. I 47, pp. 21, 3 1, 38, 40; No. 176, pp. I $52-153$; Grunau, vol. 2 (as 
a painting (c. I 480) depicting the siege of Marienburg (Pol. Malbork) in I 46049 (figs. 2 and 3 ).

Another term, i.e., handror, is used much more sporadically and it appears only in the early i 6 th century records. ${ }^{\circ}$ Regrettably, although the sources sometimes say more about guns themselves (e.g., mesingks handror or brass hand-held guns around 1523 at Preußisch Mark (Pol. Przezmark) ${ }^{\text {s1 }}$; alte hantroer and toppelt handtroer in 1524 at Rhein (Pol. Ryn) ${ }^{52}$ ), they do not provide any data on their stocks. In can be supposed that stocks for handbuchsen and handroren underwent a more or less the same evolution as everywhere else, i.e., from simple wooden shafts on which gun barrels where mounted (or shafts inserted into sockets in rear parts of barrels, see fig. 4) to fully developed gunstocks with properly shaped butts (figs. 5 and 6)..$^{3}$

An archaeological example of such an early handbuchse from the territory of the Teutonic Order's state is an early i sth century find from the Curonian Spit near the locality of Schwarzort, discovered during dredging works in I 87 I (fig. 7 ). The gun is provided with a $5.9 \mathrm{~cm}$ long socket, into which an oak wood shaft was inserted. The shaft, being perhaps a late i 9 th century reconstruction (although survival of original wood in waterlogged environment cannot be completely excluded), was octagonal in cross-section and its length was $54 \mathrm{~cm}$. Its diameter in the socket was $3.8 \mathrm{~cm}$ while in its end part it was $4.05 \mathrm{~cm}$ thick. Interestingly, there was a cavity in the end part of the stock. It accommodated a c. $39.3 \mathrm{~cm}$ long and I. I cm thick oak wood ramrod. ${ }^{54}$ Another gun of such type and chronology (of

n. 34), pp. 399, 420, 55 I-552; Nanker (as n. 37), p. 298; see also Stępiński, Żabiński, Strzyż (as n. I 8), pp. $178-179$.

49 Konieczny (as n. I 9), pp. I 99-20 I, fig. XIIIa; Szymczak (as n. I 9), 3 I 0 ; Strzyż, Broń palna (as n. 20), pp. 45-46, fig. 3; idem, Średniowieczna broń palna (as n. 20), p. 20.

so GÄDO (as n. 26), pp. 76, I 49, I 87, 204, 206; Biskup (as n. 28), pp. Iо I-1 02.

s1 Biskup (as n. 28), p. 102; Szymczak (as n. 19), 45.

s2 GÄDO (as n. 26), p. 204.

53 Strzyż, Broń palna (as n. 20), pp. 25-34, 38-46, 67-72; S. McLachlan, Medieval handgonnes. The first black powder infantry weapons (Osprey Weapon 3), Oxford 2010, pp. 28-31, 37; R. D. Smith, K. DeVries, The Artillery of the Dukes of Burgundy, 1363-1477, Woodbridge 2005, pp. 2 17-2 I 8; E. Oakeshott, European Weapons and Armour. From the Renaissance to the Industrial Revolution, Woodbridge 2000, pp. 3 I-33; Mielczarek, Ręczna broń palna (as n. 19), p. 6 I; L. K. Makovskaya, Ručnoe ognestelnoye oruže russkoy armii konca XIV-XVII v., Moskva I 992, pp. 28-29, 42-43, I 2 I-I 22, figs. I 8-24; pp. I 23-I 25, figs. 26-37; p. I 28, fig. 44; Głosek (as n. 19), p. I 58 ; Konieczny (as n. 19), pp. I 88-192, figs. VII-IX; pp. 199-2 I I, figs. XIIIa-XXII; Rathgen, Das Geschütz (as n. 4), pp. 72-74, I 29, 535-537; K. Górski, Historia artyleryi polskiej, Warszawa 1902, pp. 30-31.

54 Strzyż, Broń palna (as n. 20), pp. 38-40, 43, table I; p. 289, plate IX.7-9, cat. No. 95; idem, Średniowieczna broń palna (as n. 20), pp. I8, I24, cat. No. 8; p. 2 18, plate II.I-3, cat. No. 8; 
unknown provenance, but possibly related to the Order's state) is stored in the Museum in Lębork (Germ. Lauenburg). The barrel is $5 \mathrm{I}$.I cm long and the calibre is $1.65 \mathrm{~cm} .55$

Another type of hand-held firearms was hackbut (bakenbuchse), i.e., a gun with a hook it its front part, which could be supported against a wall or a shield. ${ }^{56}$ Interestingly, first mentions of hackbuts in written sources appear only in the mid$15^{\text {th }}$ century and they are more numerous in the early I 6th century ${ }^{57}$ It could be supposed that in earlier sources hackbuts may have been simply recorded under handbuchsen. Also in this case the sources sometimes provide more information. Extra small or extra large hackbuts were sometimes referred to as half-hackbuts (balbehacken) $)^{58}$ or double hackbuts (dhoppelthacken) ${ }^{59}$ respectively. In some cases the sources say that some hackbuts stored in a given locality are old (in I 52 I at Preussisch Mark (Pol. Przezmark): hogkenbuchszen and alde hogken ${ }^{60}$, alte hocken in I 524 at Rhein (Pol. Ryn $\left.{ }^{61}\right)$. In I 524 at Rhein boehemysch hocken were recorded. ${ }^{62}$ Analogously to handbuchsen, hackbuts with brass barrels (mesigkes or mesingks hacken) (figs. 8 and 9) are sometimes mentioned, e.g., about I 523 at Königsberg (Russ. Kaliningrad) and at Preußisch Mark (Pol. Przezmark). ${ }^{63}$ On the other hand, a hackbut with an iron barrel (fig. Iо) was explicitly mentioned in 15 I 8 at Preußisch Holland (Pol. Pasłęk). ${ }^{64}$ As in the case of handbuchsen, nothing closer was said on hackbut stocks. Based on data provided by P. Strzyż, it is possible to say that hackbut stocks also underwent a considerable evolution from

Szymczak (as n. 19), pp. 36, 38, fig. 4; Konieczny (as n. 19), p. I 85, fig. V; Rathgen, Das Geschütz (as n. 4), pp. 73-74; M. Thierbach, Über die erste Entwickelung der Handfeuerwaffen, Zeitschrift für Historische Waffenkunde I (1897-1 899), 6, pp. I $30-$ I 3 I.

ss Strzyż, Broń palna (as n. 20), pp. 42, 290, plate X.I-3, cat. No. 96; idem, Średniowieczna broń palna (as n. 20), pp. I 8-19, I 23 , cat. No. 6; p. 2 19, plate III. I-3; cat. No. 6.

56 Szymczak (as n. 19), pp. 4 I-45; Mielczarek, Ręczna broń palna (as n. 19), pp. 62-63; Głosek (as n. I9), p. I 58 ; Rathgen, Das Geschütz (as n. 4), pp. 62-67.

57 Biskup (as n. 28), pp. IоI-I02; GÄDO (as n. 26), pp. 50, 60, 65-71, 73-74, 79, I09-I I I, II3-II 5, II7-II 8, I20-I23, I47-I49, I74-I75, I77, 654, I84-I85, I87-I9I, I99-200, 202, 204, 206-209, 247, 250-25I, 254, 256, 297, 314, 338-340, 342, 348, 353, 355-356, 358-359; Grunau, vol. 3 (as n. 34), pp. 483, 520, 534, 54I; KKMT (as n. 30), No. I 5; Regesta, vol. 3 (as n. 38), No. 23 1 37, p. 2 1 7; No. 23 192, p. 220 ; see also Stępiński, Żabiński, Strzyż (as n. I 8), p. 179 .

58 GÄDO (as n. 26), p. I 23; Biskup (as n. 28), pp. 101-102.

59 Biskup (as n. 28), pp. I I-1 o2; on this issue see also Szymczak (as n. 19), p. 4 I.

$60 \mathrm{GÄDO}$ (as n. 26), p. 149.

61 GÄDO (as n. 26), p. 204.

62 GÄDO (as n. 26), p. 204.

63 Biskup (as n. 28), p. 101-102.

$64 \mathrm{GÄDO}$ (as n. 26), p. I I I. 
simple straight beds or rods inserted into barrels' sockets to well-profiled stocks with ergonomically shaped butts (fig. I I). ${ }^{65}$

A very interesting record concerning firearms' stores at the capital castle in Marienburg (Pol. Malbork) comes from the year I 448. It mentions 22 hantbuchsen mit 39 kamern $^{66}$, i.e., hand-held veuglaires with detachable powder chambers. In this case, the construction of their stocks must have been quiter sophisticated. ${ }^{67}$ P. Strzyż mentions numerous examples of small calibre veuglaires and supposes that such weapons may have sometimes been mounted on trestles with the use of rotating Y-shaped holders. ${ }^{68}$

In I 4 I 4 in Elbing (Pol. Elbląg) i 3 cleine lotbuchsen were recorded, apart from Io large ones. ${ }^{69}$ Although it is rather obvious that the former were hand-held fire$\mathrm{arms}^{70}$, it seems impossible to say anything closer about them. An inventory from Christburg (Pol. Dzierzgoń) from I 434 mentions "small short guns" (cleyne kurcze buchsen). ${ }^{71}$ It can be tentatively proposed that this concerns a very primeval form of hand-held firearms, which consisted of very short barrels mounted on simple wooden stocks or shafts. ${ }^{72}$ It could also be supposed that a mention of "rod guns" (rutebuchsen) from Ortelsburg (Pol. Szczytno) from I $520^{73}$ may concern such ear-

65 Strzyż, Broń palna (as n. 20), pp. 34-36, 46-66, 286, plate VI, cat. Nos. 21-22; p. 292, plate XII.5-7, cat. No. 57; p. 295, plate XV.2, cat. No. 16; p. 296, plate XVI, cat. No. 24; p. 297, plate XVII.I-3, cat. No. 25; p. 298, plate XVIII.5-7, cat. No. 28; p. 305, plate XXV.I-3, cat. No. 38 , plate XXVI.5-6, cat. No. 4I; p. 333, plate LIII.6-7, cat. No. 139; p. 334, plate LIV, cat. No. 2; p. 339, plate LIX.I-4, cat. No. I 4I; p. 343, plate LXIII, cat. No. 50; p. 360, plate LXXX.4, cat. No. 65, cat. Nos. 2, I 6, 2 I-22, 24-25, 28, 38, 4I, 50, 57, 65, I 39, I 4 I; see also idem, Średniowieczna broń palna (as n. 20), pp. 2 I-26 and Szymczak (as n. I9), p. 42, Fig. 8.

${ }_{66} \mathrm{MÄB}$ (as n. 26), pp. I 43-I 44; Chodyński, Magazyny broni (as n. I I), p. I 88; Rathgen, Das Geschütz (as n. 4), pp. 398-399; idem, Die Pulverwaffe (as n. 4), p. I 3.

${ }_{67}$ On possible hand-held veuglaires in Köln in the mid- I ${ }^{\text {th }}$ century see Rathgen, Das Geschütz (as n. 4), p. 3 I 7 .

68 Strzyż, Broń palna (as n. 20), pp. 94-95, 367, plate LXXXVII, cat. Nos. I Io- I I I; idem, Średniowieczna broń palna (as n. 20), pp. 30-32, I 24, cat. Nos. I 3-1 4; p. 224, Plate VIII.I-7.

69) NKRSME II (as n. 29), p. 78.

70 Cf. Rathgen, Das Geschütz (as n. 4), p. 396.

${ }_{71} \mathrm{GÄDO}$ (as n. 26), p. 142.

72 Strzyż, Broń palna (as n. 20), pp. 25-34: for the most representative examples see p. 28 I, plate I, cat. No. 17; p. 282, plate II.4-7, cat. No. 20; p. 283, plate III, cat. No. I 25; p. 284, plate IV, cat. Nos. I 4, I 8, 47, 48; p. 28 5, plate V, cat. No. 94; p. 290, plate X.4-6, cat. Nos. I 4, I 7, I 8, 20 47, 48, 94, I 25, I 93; idem, Średniowieczna brón palna (as n. 20), pp. I 5-2 I, I 23 - I 24, cat. Nos. 3, 6, 8; p. 2 1 7, plate I, cat. No. 3; p. 2 I 8, plate II, cat. No. 8; p. 2 I 9, plate III, cat. No. 6; see also Szymczak (as n. 19), pp. 36-4I.

$73 \mathrm{G} \ddot{\mathrm{A} D O}$ (as n. 26), p. 122. 
ly hand-held firearms. Furthermore, from 1477 comes a mention of "key guns" (schlusselbuchszen) from Osterode (Pol. Ostróda)..$^{74}$

Concerning artillery, in the period up to the end of the i 5 th century there is a variety of terms which cannot always be precisely linked to a given type of cannon. It is only in the early i 6 th century that the terminology becomes more precise. ${ }^{75}$ For Central Europe this seems to have been first of all caused by reforms of Maximilian I, who attempted at dividing artillery into clearly defined types using standardised ammunition. It is also this ruler who is believed to have introduced a new type of artillery carriages (so-called double bracket carriages) on a mass scale. These replaced carriages of old type, so-called Burgunderlafetten. The latter were composed of two parts - the lower one and the upper one, on which the barrel rested and which could be raised or lowered to change the angle of fire. ${ }^{76}$ This significant change was possible due to the invention of trunnions. It simplified the construction of carriages and made it possible to change the angle of elevation without the need to raise or lower the entire barrel..$^{77}$

Concerning light artillery, guns using lead ammunition should be discussed first. Guns referred to as grosse lotbuchsen are mentioned in sources only in the first half of the 15 th century. ${ }^{78}$ It could be suggested that such guns may have been mounted on various kinds of stands or trestles (fig. I 2 ). ${ }^{79} \mathrm{~V}$. Schmidtchen shows an example of a heavy $(94 \mathrm{~kg})$ lotbuchse mounted on a trestle provided with an aiming bracket. $^{80}$ There are mentions of lead bullet guns on such trestles from I 4 I 6 and I 42 I in inventories of weaponry at Nessau (Pol. Wielka Nieszawa). Interestingly, these sources mention 7 lotbochsen and 3 stands (gestellen) only (in I 4 I $6-7$ lot-

74 GÄDO (as n. 26), p. 340.

75 Cf. Świętosławski (as n. I o), p. 20, n. 6; on standarisation of artillery and its terminology at the turn of the 15 th and $16^{\text {th }}$ centuries see also Szymczak (as n. I9), pp. 65-69.

${ }_{76}$ Rathgen, Das Geschütz (as n. 4), p. I 30 ; W. Boeheim, Studien über die Entwickelung des Geschützswesens in Deutschland, Zeitschrift für Historische Waffenkunde I (1897-1899), 3, p. 58; on Maximilian's artillery see also e.g. Chodyński, Habsburg artillery (as n. I I), pp. 5 I -59; D. Goetz, Die Anfänge der Artillerie, Berlin 1985, pp. 33-34; on the new type of carriage see Szymczak (as n. i9), p. 70.

77 Strzyż, Broń palna (as n. 20), pp. 77-78; idem, Średniowieczna broń palna (as n. 20), p. 38; Szymczak (as n. I9), pp, I 5-1 7, 7 I; Mielczarek, Artyleria (as n. I9), p. 7 I; H. Müller, Deutsche Bronzegeschützrohre 1400-1750, Berlin 1968, p. 41; Rathgen, Das Geschütz (as n. 4), pp. I 30-I 3 1, 526; Górski (as n. 53), p. 33.

78 GÄDO (as n. 26), pp. I05-106, 369, 370, 744, 746, NKRSME II (as n. 29), p. 78; Visitationen I (as n. 26), No. 92, p. I I 9; Visitationen 2 (as n. 26), No. 176, pp. I 52-1 53.

79 Schmidtchen (as n. 6), pp. 20-22; Rathgen, Das Geschütz (as n. 4), p. 396.

80 Schmidtchen (as n. 6), p. 2 I, fig. I 3. 
buchsen $c z$ u gestellen $)^{81}$; in I 42 I -7 lotbochsen und 3 gestellen. ${ }^{82}$ From I 4 I I there comes a mention of a large gun to be brought with its trestle to the Town Hall in Elbing (Pol. Elbląg) (de grote bussen up dat Rathus to bringen mit dem stellen).8.3 Furthermore, in I44I a large lead bullet gun in a wooden stock was recorded at Althaus (Pol. Starogród) (grosse lotbuchse in einer holczladen ${ }^{84}$; bochsen in holczen laden were also mentioned at Birgelau (Pol. Bierzgłowo) in 1440 and $144{ }^{85}$ ). A trestle-gun (bockpuchsel) was also mentioned at Königsberg (Russ. Kaliningrad) about $1523{ }^{86}$ Perhaps at that time this type of cannon was already rather old-fashioned.

Analogous stands and trestles may have also been used for terrace-guns (tarrasbuchsen), i.e., light cannons deployed on castle terraces (fig. I 3$).{ }^{87}$ On the other hand, examples of terrace-guns on wheeled carriages are also known. B. Rathgen mentions a purchase of a pair of wheels for a terrace-gun in Naumburg an der Salle in I 449; however, he believes that this gun was actually a field cannon. ${ }^{88}$ Such guns could fire both metal and stone projectiles. A majority of mentions concerning them is known from the first half of the is th century, although they also sporadically occur in later sources. ${ }^{89}$

Another kind of cannons which appears in sources were small guns launching stone projectiles (cleyne steynbochsen). Such guns are mostly mentioned in

8I GÄDO (as n. 26), p. 48 I.

$82 \mathrm{GÄDO}$ (as n. 26), p. 482.

83 NKRSME II (as n. 29), 3 I; Chodyński, Inwentarz broni (as n. I I), p. 72; Chodyński, The stores of arms (as n. I I), p. I 7 .

84 GÄDO (as n. 26), p. 5 II.

85 GÄDO (as n. 26), pp. 455, 457; see also Stępiński, Żabiński, Strzyż (as n. i 8), p. 177.

86 Biskup (as n. 28), p. I oo; on such guns see also Szymczak (as n. 19), pp. 58-59, idem, Broń palna $w$ arsenatach zamkowych i miejskich $w$ Polsce XV wieku, in: Szlachta, starostowie, zaciężni, ed. B. Śliwiński (Gdańskie Studia z Dziejów Średniowiecza 5), Gdańsk-Koszalin 1998, p. 285 ; and idem, Die Feuerwaffenvorräte in den Schloß-und Stadtarsenalen in Polen in der 2. Hälfte des I5. und am Anfang des I6. Jahrhunderts, Fasciculi Archaeologiae Historicae 9 (1996), p. Io.

87 Strzyż, Broń palna (as n. 20), pp. 72-84; Szymczak (as n. 19), pp. 53-55; Mielczarek, Artyleria (as n. 19), pp. 67, 69; Goetz (as n. 76), pp. 29-30; Schmidtchen (as n. 6), p. 19; Rathgen, Das Geschütz (as n. 4), pp. 57, I29-1 30, 332-335; Górski (as n. 53), pp. 16-19.

88 Rathgen, Das Geschütz (as n. 4), pp. I 56, I 59, 287; on wheeled carriages for terrace-guns see also Szymczak (as no. 19), p. 70; and idem, Broń palna (as n. 86), p. 294.

89 GÄDO (as n. 26), pp. 30, 45, 50, 88, 92, 104-106, 108, 188, 234, 281, 285, 287, 306, 309, $312,314,335,339,353,355-356,390,424,434-435,445,447-448,450,453,456,460,483$, 485-486, 519, 52 I-522, 53 I-533, 600, 603, 605, 608, 610, 6I 6, 634-635, 640, 643-644, 694, 697, 699, 701, 703, 705-706, 708-709, 729-730, 742; MKB (as n. 24), p. 282; Visitationen I (as n. 26), No. 90, p. I I I; No. I 16, p. 2 I I No. I 20, p. 249; No. I 22, p. 259-260; No. I 23 , p. 261-262; No. 1 25, p. 278; Visitationen 2 (as n. 26), No. 176, p. I $52-153$; see also Stępiński, Żabiński, Strzyż (as n. I 8), 176. 
the period from the late $\mathrm{I} 4$ th to the mid- $\mathrm{I} 5$ th century, while only one record is known from the first quarter of the 16 th century..$^{\circ 0}$ Only in a few cases the sources provide more information on stands of such guns. In I 409 at Marienburg (Pol. Malbork) 2 small stone cannonball guns composed of two parts were mentioned. The one had one screwed-in powder chamber, while the other had three insertable powder chambers ( 2 cleyne steynbochsen ycliche von 2 stocken, eyne geschruwete mit eyme polfergehuse, dy ander nicht geschruwet mit 3 polferhusen). ${ }^{91}$ This means that these guns were veuglaires, and their stands must have been properly shaped to accommodate removable powder chambers. It is unknown, however, whether stands for these guns were wheeled or not. On the other hand, an explicit reference to small stoneball cannons on wheeled stands is known from the same year from the Order's capital castle, where cleyne steynbochsen of den karren were recorded.92 Furthermore, there is a series of records from the years I 43 I-I 438 concerning stores of firearms at Schlochau (Pol. Człuchów). They mention stone cannonball guns in iron-fitted stands, or in fully iron-fitted stands (steynbuchsen in laden beslagen or steynbuchsen in wol beslagen laden). ${ }^{93}$ Obviously, the size of these cannons was not specified, but these records are anyway a valuable mention concerning the construction of stocks.

As far as wheeled stands are concerned (fig. I4), there is a series of records which directly mention guns on some sort of wheelbarrow-like carriages (carrenbuchsen).${ }^{94}$ Interestingly, such records are sporadic in the first half of the i 5 th century and it is first in the early i 6th century that they become much more numerous. ${ }^{95}$ This may be in line with a belief that wheeled carriages became more

90 Ältere Hochmeisterchronik (as n. 32), p. 675; GÄDO (as n. 26), pp. 7, 1 6, 86, 92, I 04, I 27, I 32 , 236, 238, 240, 306, 3 I 4, 353, 4I 2, 436, 438, 447-448, 450, 453, 456, 548-549, 593, 603, 608, 610, 616, 640, 64I-644, 650, 656, 694, 697, 699, 70 I, 705-706, 742, 749-75 I, 756, 758, 760, 768; MÄB (as n. 26), pp. I 4-I 5, 19-20, I 43; MTB (as n. 23), pp. 558, 573; Visitationen I (as n. 26), No. 91, p. I I I; No. I 20, p. 249; No. 133, p. 305 ; Visitationen 2 (as n. 26), No. I 47, pp. 28, 107.

${ }_{91}$ MTB (as n. 23), p. 558; Żabiński, Technology of manufacture (as n. 17), p. 90; Stępiński, Żabiński, Strzyż (as n. I 8), p. I73; Świętosławski (as n. Io), p. 22; Schmidtchen (as n. 6), p. 60; Rathgen, Das Geschütz (as n. 4), p. 406; Rathgen, Die Pulverwaffe (as n. 4), p. 29; Górski (as n. 53), p. 26; Engel, Nachrichten über Waffen (as n. 3), p. 23 I; Toeppen (as n. I), p. I 52.

92 MTB (as n. 23), p. 573; Rathgen, Das Geschütz (as n. 4), pp. 407, 420.

93 GÄDO (as n. 26), pp. 658, 660, 663, 665, 668-669.

94 See e.g. Schmidtchen (as n. 6), p. I9; Müller (as n. 77), p. 39, fig. 20; Rathgen, Das Geschütz (as n. 4), p. 130, 238-239, 243, 245-246.

95 GÄDO (as n. 26), pp. 50, I I 2, I 23, I 47-I 48, I 84-I 85, I 89-190, I 99-200, 207-208, 344-345, 348-349, 358-359; Geschichten (as n. 37), p. 132; Johann Lindaus (as n. 37), pp. 509, 516, 61 8; MTB (as n. 23), pp. 573, 579; Regesta, vol. I (as n. 38), No. 386 I, p. 243. 
popular in the first half of the 15 th century. ${ }^{96}$ On the other hand, there are several mentions of wheeled carriages from as early as the late 14 th century. ${ }^{97}$ Also in this case almost nothing is said on the construction of these carriages. Only in I 409 at Marienburg (Pol. Malbork) a payment for a blacksmith Swenkenfeld for fitting one gun on a carriage was recorded (Swenkenfelde dem smede vor I bochse of eyme karren zu beslohen)..$^{8}$ "Carriage guns" varied with regard to their size. Small "carriage guns" were recorded in 1409 at Marienburg99, in I 516 at Osterode (Pol. Ostróda) ${ }^{100}$, in I 5 I 8 at Preußisch Holland (Pol. Pasłęk) $)^{101}$, or in I 52 I at Ortelsburg (Pol. Szczytno). ${ }^{102}$ Large guns of that kind were mentioned in 1516 at Osterode. ${ }^{103}$

Another not quite precise term which is used in reference to light and perhaps also some medium-sized cannons is field gun (hawfnitz) (fig. I 5), i.e., a gun accompanying troops in the field. ${ }^{104}$ Such guns are mentioned in written sources only in the second half of the 15 th and the first quarter of the 16 th century, ${ }^{105}$ which obviously does not mean that they were not used in earlier times. Guns of this kind were mounted on various types of stands, also including wheeled ones. ${ }^{106}$

96 See e.g. Głosek (as n. 19), p. 157.

97 R. Heś, Początki broni palnej w Zgorzelcu (Görlitz) 1393-1420, Acta Militaria Mediaevalia 5 (2009), p. I41; Szymczak (as n. 19), p. 70; Goetz (as n. 76), p. 37; Rathgen, Das Geschütz (as n. 4), pp. I9, 39-40, 52, 169, 174, 238-239, 243, 245-247, 323, 325, plate 3.8 .

98 MTB (as n. 23), p. 579; Żabiński, Ways of acquisition (as n. I7), p. I 30 ; Rathgen, Das Geschütz (as n. 4), p. 408; idem, Die Pulverwaffe (as n. 4), p. 3 I; Toeppen (as n. I), p. 235 ; Engel, Nachrichten über Waffen (as n. 3), p. 230.

$99 \operatorname{MTB}($ as n. 23), p. 573.

${ }_{100}$ GÄDO (as n. 26), pp. 348-349.

101 GÄDO (as n. 26), p. I 12.

${ }_{102} \mathrm{GÄDO}$ (as n. 26), p. 123.

${ }_{103}$ GÄDO (as n. 26), pp. 348-349.

${ }_{104}$ See Strzyż, Broń palna (as n. 20), pp. 84-92; Szymczak (as n. 19), pp. 60-6 I; Mielczarek, Artyleria (as n. 19), p. 70 ; Głosek (as n. 19), p. I 57 ; Górski (as n. 53), p. 20-2 I.

ros GÄDO (as n. 26), pp. I09-1 10, I 88, 341-342; Grunau, vol. 3 (as n. 34), pp. 466, 553-555, 654; KŻZP (as n. 3 I ), p. 103.

${ }_{106}$ See e.g. Strzyż, Broń palna (as n. 20), pp. 89, 91-92, fig. I3; Szymczak (as n. 19), p. 61; Müller (as n. 77), p. 33, fig. 13; p. 35; It is interesting that the only surviving cannon which can be related to the Order, that is, the early i 5 th century gun from Kauernick (Pol. Kurzętnik) can actually be classified as a light field cannon. Regrettably, only the barrel of the gun (c. $42.28 \mathrm{~kg}$ ) survived, see Strzyż, Broń palna (as n. 20), pp. 85-87, 364-365, plates LXXXIV-LXXXV, cat., No. 102; Stępiński, Żabiński, Strzyż (as n. I 8), pp. 155-16 I, figs. I-9; Strzyż, Średniowieczna brońpalna (as n. 20), pp. 34-35, I 23, cat. No. 5; p. 225 , plate IX, cat. No. 5. A good example of a wheeled carriage for light field cannons is that of a wrought iron gun from the collection of the Zeughaus in Berlin. The cannon itself may be of Burgundian origin and it is dated to the second half of the $\mathrm{s} 5$ th century. The barrel is mounted on a two-part bed with a split-trail elevation, with the use of iron fittings. The cannon's wheels are iron-fitted, too, see Strzyż, Bron palna (as n. 20), p. 89, fig. I 2; Smith, DeVries (as n. 53), pp. 3 I0-3 I I, No. 25. 
With regard to medium-sized cannons, in written sources from the period of I $408-$ I 454 there are such terms as mittelbochse, mittelmessige bochse, mittelmessige steynbuchze or mittelsteynbuchsen. ${ }^{107}$ Only in one case it is possible to say more on their size - 2 mittelbochsen recorded in 1408 at Marienburg (Pol. Malbork) weighed 9.5 Zentners (i.e., over $450 \mathrm{~kg}$ ) each. ${ }^{108}$ The earliest guns of that size may have rather been mounted on immovable stands, but wheeled carriages must also be taken into consideration for later periods.

A very ambivalent term which appears in written sources is no doubt "large guns" (grosse buchsen). It seems that this term may have been used both in reference to very heavy artillery (including the heaviest cannons), as well as to cannons which were simply larger than other ones which were stored in a given arsenal when an inventory or visitation report was written. This may especially be true in the case of earlier records. Chronologically, the term grosse buchse appears throughout the entire period in question, but is used rather exceptionally in records which are later than 1466 (i.e., the end of the Thirteen Years War between the Order and Kingdom of Poland). ${ }^{109}$ An interesting example is the Teutonic Order's record from c. 1523 , mentioning one huge cannon (das grosse hawptstugk - see below with fig. 25). ${ }^{110} \mathrm{It}$ is only sporadically that the actual or even approximate sixe of such guns can be assessed (e.g., heavy cannons cast at Marienburg (Pol. Malbork) in 1408-1409, including the Grose Bochse - a veuglaire weighing perhaps over I 3 tons). ${ }^{111}$ The situation is not much clearer concerning another similar term

107 GÄDO (as n. 26), pp. 86, 88, 436, 438; Geschichten (as n. 37), pp. 1 38-139; MTB (as n. 23), pp. 5 II 558.

${ }_{108}$ MTB (as n. 23), p. 5 I I; Rathgen, Das Geschütz (as n. 4), p. 406; idem, Die Pulverwaffe (as n. 4), p. 27.

$109 \mathrm{ABMH}$ (as n. 25), pp. 17, 2 1; Ältere Hochmeisterchronik (as n. 32), p. 699; Biskup (as n. 28), p. I00; GÄDO (as n. 26), pp. 7, I 6, 97, I I 2, I 30, 21 7, 21 19, 226-228, 240, 306, 3 I 4, 3 I 8, 329, 429-430, 435-436, 456, 460, 480-48 I, 6I 4-6 I 5, 648-649, 65 8, 672, 68 5-686, 688, 690, 699, 767-768; Geschichten (as n. 37), pp. I I 8, I 36, I 38 - I 39, I 45; Jüngere Hochmeisterchronik (as n. 33), pp. 139-1 40; KKMT (as n. 30), No. 32; Johann Lindaus (as n. 37), p. 509; MÄB (as n. 26), pp. I 4-1 5; MTB (as n. 23), pp. 479-480, 483, 496, 497, 501, 502, 506, 5 10-5 I I, 5 I 5 , 557, 558; NKRSME II (as n. 29), pp. 10, 31; Visitationen I (as n. 26), No. 107, pp. 183-184; No. I I I, p. 187; Visitationen 2 (as n. 26), No. 147, pp. 24, 3 I.

110 Biskup (as n. 28), p. 100.

${ }_{11}$ MTB (as n. 23), pp. 479-480, 483, 496, 497, 501, 502, 506, 5 10-5 I I, 5 1 5, 557, 558; Posilge (as n. 35), p. 292; Żabiński, Technology of manufacture (as n. 17), pp. 89-92, 99-100, 102, tab. 3; p. 103; Strzyż, Broń palna (as n. 20), pp. 108, 217, 223-224; Stępiński, Żabiński, Strzyż (as n. I 8), pp. I 66-167, I69, tab. I; pp. I73-1 74; Żabiński, The Grose bochse (as n. 17), pp. 3 I-4 I; Strzyż, Średniowieczna broń palna (as n. 20), p. 38; Szymczak (as n. 19), pp. 108, i 85; Nowakowski, Źródta zaopatrzenia (as n. 7), p. 334; Schmidtchen (as n. 6), pp. 46-47, 56-62; Rathgen, Das Geschütz (as n. 4), pp. 405-41 5, 419-420, 464-465; idem, Die Faule Grete (as 
"large stoneball cannons" (grosse steynbuchsen). As in the previous case, its use is chiefly limited to the end of the I 4 th and the first half of the i 5 th century ${ }^{112}$ Another term for large guns - in this case, with extraordinarily long barrels - was "long gun" (lange bochse). It first appears only in 1409 in reference to guns cast in Danzig (Pol. Gdańsk) (cleyne lange bochse [...] mit 3 polfergehusen, i.e., a veuglaire ${ }^{113}$; lange bochse $\left.{ }^{114}\right)$. Lange steynbochsen were also recorded in 1428 at the farm in Alt-Thorn (Pol. Stary Toruń). ${ }^{115}$ As far as the heaviest guns are concerned, it seems obvious that such cannons were mounted on immobile stands or beds (fig. I6), and wheeled carriages went into use only in the end of the $15^{\text {th }}$ century, as sizes of the largest cannons became significantly diminished, due to the use of cast iron projectiles (fig. I 7 ). ${ }^{116}$

Yet another type of cannons which appears in written records are veuglaires. ${ }^{17}$ Such guns are known from the period between the early i 5 th century and the first two decades of the I 6 th century, but most mentions concern times up to the midI 5 th century ${ }^{118}$ This may imply that in later period these cannons were considered obsolete. P. Strzyż stressed the fact of a gradual abandonment of veuglaires in the

n. 4); idem, Die Pulverwaffe (as n. 4), pp. 25-41; Engel, Nachrichten über Waffen (as n. 3), pp. 230-231; Toeppen (as n. I), pp. I 45-152, 228-229.

${ }_{112}$ Ältere Hochmeisterchronik (as n. 32), p. 675; Biskup (as n. 28), p. 100; GÄDO (as n. 26), pp. I6, 60, 86, 88, 90, 92, 97, 104-106, I 27, I 32, 236, 353, 403, 434, 438, 447-448, 450, 453, 460, 483 , $548-549,603,605,608,610,616,626,630,640-644,650,656,660,663,665,668,694,697$, 701, 703, 705-706, 708-709, 742, 749-75 1, 756, 758, 760; Jüngere Hochmeisterchronik (as n. 33), pp. I 39-1 40; MÄB (as n. 26), pp. 19-20, 22-24; Visitationen I (as n. 26), No. 91, p. I I I; No. I20, pp. 249-250; No. I25, p. 278; No. 133, p. 305; Visitationen 2 (as n. 26), No. 147 , p. 28 ; No. 176 , pp. $152-153$.

${ }_{113} \mathrm{MTB}$ (as n. 23), pp. 554, 559, 573.

${ }_{114}$ MTB (as n. 23), pp. 590-591; on such guns see also Świętosławski (as n. 10), p. 23; Rathgen, Das Geschütz (as n. 4), pp. 407-408; Rathgen, Die Pulverwaffe (as n. 4), p. 33.

in G ̈̈̈DO (as n. 26), p. 443.

${ }_{116}$ See e.g. Strzyż, Broń palna (as n. 20), pp. ı09-ı Io, fig. I 8; Smith, DeVries (as n. 53), p. 209; Szymczak (as n. 19), pp. I 5-1 7, 64, 7 1, I 52; A. R. Williams, A. J. R. Paterson, A Turkish bronze cannon in the Tower of London, Gladius 17 (1986), p. I 87; Goetz (as n. 76), pp. 27-28, 43; Schmidtchen (as n. 6), pp. I 8-19, fig. 8; Müller (as n. 77), pp. I9, 29, fig. I I; Rathgen, Das Geschütz (as n. 4), pp. 227-228, 235; Górski (as n. 53), pp. 24-25, 33.

${ }_{117}$ On veuglaires see e.g. Strzyż, Broń palna (as n. 20), pp. 92-104; idem, Średniowieczna broń palna (as n. 20), pp. 30-33; Smith, DeVries (as n. 53), pp. 230-236; Szymczak (as n. 19), pp. 55-56; Mielczarek, Artyleria (as n. 19), p. 69; Goetz (as n. 76), pp. 28-29; J. F. Finó, L'artillerie en France à la fin du Moyen Age, Gladius I 2 (1974), pp. 2 I-22; Rathgen, Das Geschütz (as n. 4), pp. 54-60, 397-399, 538-550, 557-559; Górski (as n. 53), pp. 19-20.

${ }_{118}$ GÄDO (as n. 26), pp. 69-70, 105-106, I08, I I I, I65, I 88-190, 436, 438, 443, 45 I, 455, 485 , 544, 652-653, 656, 671 , 744, 747-748; Grunau, vol. 3 (as n. 34), pp. 276-277; KKMT (as n. 30), No. I 5; Johann Lindaus (as n. 37), pp. 603-605; MTB (as n. 23), pp. 479, 480, 483, 496, 497, 501, 502, 506, 5 10, 5 1 I, 5 1 5, 554, 558-559, 573; Regesta, vol. 3 (as n. 38), No. 2042 I, 
I 6th century due to difficulties with securing a proper tightness of the powder chamber-chase connection, and the appearance of new types of low calibre cannons. Furthermore, the process of charging of cannons became quicker and more efficient, thus rendering removable powder chambers obsolete. ${ }^{119}$ Also in this case these mentions do not contain much data on the construction of stands or carriages. It is known that a variety of immovable stands and wheeled carriage types were used for such cannons, depending on the size and other traits of such guns. ${ }^{120}$

When dealing with veuglaires, it is also worth making some comments on schiffbuchssen or naval guns (fig. I 8). ${ }^{121}$ The earliest mention of their use in the territory of the Order's state concerns the battle in Frisches Haff (Pol. Zatoka Świeża) on Is September 1463 between the Order's troops and the fleets of Danzig (Pol. Gdańsk) and Elbing (Pol. Elbląg). Reports say that on some ships of the Prussian Confederacy there were bastions equipped with veuglaires. ${ }^{122}$ Interestingly, almost all later (i.e., early i 6 th century) mentions of schiffsbuchssen refer to them as veuglaires (schifbuchssen mit camern). ${ }^{123}$ It can be supposed that such a manner of loading the guns was believed to be more convenient onboard of a ship. Generally, it can be assumed that naval guns at that time were in many cases land guns which were adapted for the use on the sea.

The researcher's position is better in the case of early i 6 th century artillery. First of all, in this period cannon types commence to become more or less standardised, which facilitates the analysis. Furthermore, the introduction of cast iron cannonballs allowed to diminish the size and weight of the largest guns. Therefore, even very heavy cannons could be mounted on wheeled carriages. Of course, it did not mean a complete abandonment of stone projectiles. ${ }^{124}$ Several different types of early i 6 th century cannons in the Teutonic Order's state are known from written sources.

Falcons (falckennethlen or falckenmethlen) were light cannons with long barrels weighing around $80-200 \mathrm{~kg}$. A. R. Chodyński mentions falcons from the times of Maximilian I, which fired projectiles weighing I-I.5 pounds (about $0.56-$

p. 72; Visitationen I (as n. 26), No. 107, p. 183; Visitationen 2 (as n. 26), No. 147, pp. 21,23 , 3 1-32, 34-35, 40; No. 176, pp. I 52 - I 53; see also Stępiński, Żabiński, Strzyż (as n. I 8), p. 177.

${ }_{119}$ Strzyż, Broń palna (as n. 20), pp. 93, 102, 104; idem, Średniowieczna broń palna (as n. 20), pp. 3 I-33; see also Szymczak (as n. I9), p. 56.

${ }_{120}$ See e.g. Smith, DeVries (as n. 53), p. 236; Szymczak, Broń palna (as n. 86), p. 294; Rathgen, Das Geschütz (as n. 4), pp. 547, 550 , plate 10.36-37.

121 For this issue see e.g. Szymczak (as n. 19), pp. 289-298.

${ }_{122}$ Johann Lindaus (as n. 37), pp. 603-605; Grunau, vol. 3 (as n. 34), pp. 276-277.

${ }_{123}$ GÄDO (as n. 26), pp. 109, I 89-90.

${ }_{124}$ See e.g. Strzyż, Broń palna (as n. 20), pp. I29-130, 132; idem, Średniowieczna broń palna (as n. 20), pp. 63-65; Górski (as n. 53), pp. 35, 42-43. 
$-0.84 \mathrm{~kg}){ }^{125}$ According to a French royal ordinance from I 544, the weight of the faucon was 750 pounds (c. $367.12 \mathrm{~kg}$; I livre - c. $489.5 \mathrm{~g}$ ), while its cannonball weighed 2 pounds (c. $0.98 \mathrm{~kg}$ ). Concerning the fauconneau, these figures were 450 pounds (c. $220.27 \mathrm{~kg}$ ) and I pound respectively. ${ }^{126}$ The manual of S. de Saint Remy from 1697 states that the calibre (expressed by the weight of the projectile) of a faucon was 3 pounds (c. $1.47 \mathrm{~kg}$ ), its weight was 2300 pounds (c. I I $25.85 \mathrm{~kg}$ ), while its length was 8 feet (c. $259.84 \mathrm{~cm}$; i pied $d u$ roi - c. $32.48 \mathrm{~cm})$. In the case of a lighter fauconneau, the relevant parameters were 2 pounds (c. $0.98 \mathrm{~kg}$ ), 1 350 pounds (c. $660.83 \mathrm{~kg}$ ) and 10.5 feet $($ c. $341.04 \mathrm{~cm}){ }^{127}$ However, this author also mentions much lighter faucons and fauconneaux, weighing even as little as I 50 pounds (c. $73.43 \mathrm{~kg}$ ). ${ }^{28}$ Falcons are known from a few records from the early I 520 , with hardly any details on the construction of their carriages. ${ }^{129}$ It can be supposed that another type of light cannons were guns which were provided with a colourful name of dorndreher (literally: red-back shrikes) (mentions from c. $1523^{130}$ ).

Yet another kind of light artillery were organ guns (orgelpfeyffen) (fig. 19), i.e., cannons consisting of multiple barrels mounted on a wheeled carriage. They are known from records dated to c. I $523 .{ }^{131}$ Such guns perhaps evolved from late I 4 th century ribaudiaux, or sort of wheelbarrows provided with several small cannons. ${ }^{132}$ R. D. Smith and K. DeVries argue that a similar term ribaudequin rather referred not to a specific type of gun, but to a type of carriage on which guns were mounted. ${ }^{133}$

Serpentines (scherppentiner or schlangen) were also cannons with long barrels; however, these were significantly heavier than those of falcons. In late i 5 th century Burgundy the term serpentine referred to rather light cannons, weighing somewhat more than $200 \mathrm{~kg}$. They were in most cases mounted on wheeled carriages (fig. 20). ${ }^{134}$ In the organisation system of artillery of Maximilian I, schlangen and their subcategories were field cannons. ${ }^{135}$ A. R. Chodyński says that their barrels

\footnotetext{
${ }_{125}$ Chodyński, Habsburg artillery (as n. I I), p. 58 ; see also Goetz (as n. 76), p. 34.

${ }^{126}$ Finó (as n. I 1 7), p. 2 I; see also Górski (as n. 53), p. 34.

127 Saint Remy (as n. 43), p. 56.

${ }_{128}$ Saint Remy (as n. 43), p. 58.

129 GÄDO (as n. 26), p. 1 23; Biskup (as n. 28), pp. 100-102.

${ }_{130}$ Biskup (as n. 28), pp. 100-1 I; Boeheim (as n. 76), p. 58.

${ }_{131}$ Biskup (as n. 28), pp. 100, 102; see also Szymczak (as n. 19), p. 59.

${ }_{132}$ McLachlan (as n. 53), p. I 4; on organ guns and their variants see also e.g. Smith, DeVries (as n. 53), pp. 22 I-225; Szymczak (as n. 19), pp. 59-60; Mielczarek, Artyleria (as n. 19), p. 70; Müller (as n. 77), p. 2 I; Rathgen, Das Geschütz (as n. 4), pp. 244-245, 284, 335-336, 550-552.

${ }_{133}$ Smith, DeVries (as n. 53), pp. 237-238.

${ }_{134}$ Smith, DeVries (as n. 53), pp. 227-230.

${ }_{135}$ Boeheim (as n. 76), p. 58.
} 
weighed over 25 Zentners (c. I $400 \mathrm{~kg}$ ) while their projectiles weighed 16 pounds (c. $8.96 \mathrm{~kg}$ ). ${ }^{136}$ Saint Remy says that the weight of the serpentine's projectile was 24 pounds (c. I I.75 kg), its weight was 4300 pounds (c. $2104.85 \mathrm{~kg}$ ) and its length was I 3 feet $($ c. $422.24 \mathrm{~cm}){ }^{137}$ The earliest mention of such guns from the Order's state comes from 1485 and they were in use up to the very end of the Order's existence in Prussia. ${ }^{138}$ Extra long serpentines were called notthschlangen or lange schlangen. ${ }^{139}$ Serpentines were also divided into several subcategories, such as half-serpentines (balbschlangen) ${ }^{140}$ or quarter-serpentines (quartirschlangen). ${ }^{141}$ In one record from c. 1523 the weight of this cannon was stated and it was 4 Zentners (over I $80 \mathrm{~kg}$ ). ${ }^{142}$ Furthermore, a record from I 524 from Rhein (Pol. Ryn) suggests that a quarter-serpentine was to be transported onto the fortifications in a vessel or barrel (?) (quartyr schlaengechen in eynem gefaessz auff dy mawr). ${ }^{143}$

Carthauns or courteaux (karthawen) were heavy cannons, whose barrels weighed over $3000 \mathrm{~kg}$ (fig. 2I). Such cannons were generally used in siege warfare. Variants of cannons of this kind which were heavier or lighter were known as half-carthauns, double carthauns and so on. In the artillery reform carried out by Maximilan I, carthauns were to launch projectiles weighing 25 pounds. ${ }^{14} \mathrm{On}$ the other hand, A. R. Chodyński states that long carthauns fired projectiles weighing 48 pounds, short carthauns - 44 pounds, while 25-pound cannonballs were used for so-called Viertelbuchsen. ${ }^{145}$ In later times (about the mid- I 6th century) the term long carthauns could refer to double carthauns, whose barrels weighed I 28 Zentners (c. $7168 \mathrm{~kg}$ ) and for which 96-pound (c. $53.76 \mathrm{~kg}$ ) projectiles were

${ }^{136}$ Chodyński, Habsburg artillery (as n. I I), p. 56; see also Górski (as n. 53), p. 34; Goetz (as n. 76), p. 34; on schlangen see also Rathgen, Das Geschütz (as n. 4), pp. 3 16, 56 I; large serpentines were also mentioned in 1480 in Nancy in Lorraine, see V. Serdon-Provost, The constitution of artillery parks and fortifications for defending. The dukes of Lorraine in Nancy: a case study, in Weapons Bring Peace? (as n. 17), p. 194; on serpentines see also Szymczak (as n. 19), p. 57, idem, Broń palna (as n. 86), p. 287; and idem, Die Feuerwaffenvorräte (as n. 86), p. I I.

137 Saint Remy (as n. 43), p. 55.

${ }_{138}$ Biskup (as n. 28), pp. 100-102; GÄDO (as n. 26), pp. 50, 60, 147-1 49, 208, 31 4, 358-359; Grunau, vol. 3 (as n. 34), pp. 426, 466, 499, 553-555, 654.

139 Biskup (as n. 28), p. 102; Goetz (as n. 76), p. 34.

${ }_{140}$ Biskup (as n. 28), pp. I I-I 20; GÄDO (as n. 26), pp. I09-I IO, I I 2, I 2 I-I 22, I 47-I 48, I 77, I 84-1 85, 297; Grunau, vol. 3 (as n. 34), p. 654.

${ }_{141}$ Biskup (as n. 28), pp. I00, I02; GÄDO (as n. 26), pp. I I 2, I 49, 204.

${ }_{142}$ Biskup (as n. 28), p. 100.

${ }_{143} \mathrm{GÄDO}$ (as n. 26), p. 204.

144 Boeheim (as n. 76), p. 58; Goetz (as n. 76), p. 34; see also Strzyż, Średniowieczna broń palna (as n. 20), p. 39; Szymczak (as n. 19), p. 66; Górski (as n. 53), p. 34.

${ }^{145}$ Chodyński, Habsburg artillery (as n. I I), p. 56; see also Szymczak (as n. 19), p. 62; idem, Broń palna (as n. 86), p. 287. 
used. In the case of short carthauns, the weight of the barrel was $70-80$ Zentners (c. $3920-4480 \mathrm{~kg}$ ), while that of the projectiles $-45-70$ pounds $(25.2-39.2 \mathrm{~kg}) .^{146}$ Carthauns are known from several mentions dated to the late i 5 I os and the early I $520 \mathrm{~S}^{147}$, while halbenkarthawen were mentioned in the Order's list of firearms dated to c. $1523 . .^{148}$ Furthermore, about I 523 there were 2 syngerynes at Königsberg (Russ. Kaliningrad). These cannons were interpreted by M. Biskup as long carthauns. ${ }^{149}$

Scharfmetzen were heavy siege cannons (fig. 22). In the classification introduced by Maximilian I, their barrels weighed I 00 Zentners (i.e., about $5600 \mathrm{~kg}$, assuming that I Vienna pound was c. $0.56 \mathrm{~kg}$ ) and the weight of a projectile for such cannons was between about 50 and 100 pounds. ${ }^{150}$ These differences in projectile weight were results of later developments. ${ }^{151}$ Scharfmetzen are known from a few mentions in the period between I 5 I I and c. I $523 .{ }^{152}$

Mortars (morser) were cannons with short barrels, designed to launch projectiles in high-arching ballistic trajectories. ${ }^{153}$ The earliest mentions of such guns come from the early i 6 th century and are very sporadic. ${ }^{154}$ On the other hand, it has been suggested that a cannon depicted in a letter of a foundry master Hanns to the authorities of Danzig (Pol. Gdańsk) from I 454 (fig. 23) is actually a sort of mortar or a so-called Ellenbogengeschütz (literally: elbow-cannon). ${ }^{\text {ss }}$

Interestingly, in I 508 some kind of short mortars (kurtz buchssen fartzkacheln) were mentioned at Tapiau (Russ. Gvardyeysk). ${ }^{156}$ In contrast to many other early I6th century cannons, mortars from this period were in all probability mainly

\footnotetext{
${ }^{146}$ Chodyński, Habsburg artillery (as n. I I), p. 57.

${ }_{147}$ Biskup (as n. 28), p. I oo; Grunau, vol. I (as n. 34), p. 36 I; Grunau, vol. 3 (as n. 34), pp. 466, 499, 553-555; Hanseatische Chronik (as n. 36), p. 509.

${ }_{148}$ Biskup (as n. 28), pp. 100-102.

${ }_{149}$ Biskup (as n. 28), p. 100.

150 Strzyż, Średniowieczna broń palna (as n. 20), p. 39; Szymczak (as n. 19), p. 65; Chodyński, Habsburg artillery (as n. I I), pp. 56, 58; Goetz (as n. 76), p. 34; Boeheim (as n. 76), p. 58; see also Górski (as n. 53), p. 34.

${ }_{151}$ Chodyński, Habsburg artillery (as n. I I), p. 57.

152 Biskup (as n. 28), p. ı00; Grunau, vol. 3 (as n. 34), p. 420 ; Regesta, vol. 3 (as n. 38), No. 20885 , p. 96.

${ }_{153}$ Goetz (as n. 76), pp. 30-3 I; Rathgen, Das Geschütz (as n. 4), p. 443.

${ }_{154}$ Biskup (as n. 28), p. I00-ı I; Grunau, vol. 3 (as n. 34), p. 420.

iss Strzyż, Średniowieczna broń palna (as n. 20), p. 46; Szymczak (as n. 19), pp. I 86, I 88, fig. 28; Możejko (as n. I2), pp. 172-174; Rathgen, Das Geschütz (as n. 4), pp. 44I-442; idem, Die Pulverwaffe (as n. 4), pp. 92-94; Engel, Waffengeschichte-Studien (as n. 3), p. I I 8.

${ }_{156} \mathrm{GÄDO}$ (as n. 26), p. 60.
} 
mounted on immobile stands. ${ }^{157}$ On the other hand, the manuscript of R. Valturio shows examples of such cannons on wheeled carriages as well ${ }^{158}$ (fig. 24).

There are also numerous mentions in written sources which deal with gun stocks, stands and carriages as such. Of course, in many cases it is not possible to determine whether a given source mentions stocks for a hand-held firearms or stands or trestles for cannons. As it comes out from the above considerations, the term laden could be used for both. In I 403, the Order's Treasurer paid I 3 Scot for the transportation of 3 guns and stone projectiles to Labiau (Russ. Polesk), and 0.5 Ferto for two laden and for fitting them with iron ( 2 laden und die selben $z u$ beslan). ${ }^{159}$ It could be therefore supposed that this concerns stands for cannons. The same term laden was used clearly in reference to lead bullet guns at Marienburg (Pol. Malbork) in I 409 (0.5 Mark dem cleynsmeden vor 3 laden zu lotbochsen zu beslohen ${ }^{160}$; I.5 Mark Jauwernig dem smede vor s laden zu lotbochsen $z u$ beslohen ${ }^{161}$ ). The same was the case in 1410 in Elbing (Pol. Elblagg) - I Ferto vor is laden, lotbussen darin to leggende. ${ }^{162}$

Nevertheless, in many cases it seems impossible to determine the kind of firearms for which stocks or stands were mentioned. ${ }^{163}$ Sometimes, additional details were stated, such as the species of wood which was used. For instance, in I 409 the House Commander of Thorn (Pol. Toruń) paid 4 Marks 8 Scot and 6 Denars for oak wood and spruce or fir logs to be used for a gun stand (vor eychin zymmer und vichtynne ronen zu den bochse stonunge). ${ }^{164}$ In I 4 I I in Elbing I.5 Marks went for two oak beams (eken tymmer) for gun stands (bussenstellen). ${ }^{165}$ Elm wood was used in I 4 I 2 at Marienburg (Pol. Malbork) (vor rusternholcze czu bochszenladen czu snyden). ${ }^{166}$ In I 4 I 5 sawing of oak wood for making gun stocks or stands was recorded at the Order's capital castle (Bochsenladen [...] vor eychenholcz den

\footnotetext{
157 See e.g. Goetz (as n. 76), p. 3 I.

${ }_{158}$ Valturio (as n. 16), fol. I 26v; Rathgen, Das Geschütz (as n. 4), pp. 135-1 36.

159 MTB (as n. 23), p. 247.

${ }_{160}$ MTB (as n. 23), p. 57 I.

${ }_{161}$ MTB (as n. 23), p. 588; Świętosławski (as n. 10), p. 24; Schmidtchen (as n. 6), p. 70; Rathgen, Das Geschütz (as n. 4), p. 407-408; idem, Die Pulverwaffe (as n. 4), pp. 30, 32; Engel, Nachrichten über Waffen (as n. 3), p. 23 I; Toeppen (as n. I), pp. 233-234.

${ }_{162}$ NKRSME I (as n. 29), p. 230; Świętosławski (as n. 10), p. 24; Toeppen (as n. I), pp. 233-234.

${ }_{163} \mathrm{ABMH}$ (as n. 25), pp. 20, 36, 6I -62, 77, I I I, I I 7, I 26, I 35-I 37, I 43, I 45, I 76-I 77, 221 I, 252 , 268, 279; NKRSME II (as n. 29), p. 80.

${ }_{164}$ MTB (as n. 23), p. 597; Rathgen, Das Geschütz (as n. 4), pp. 408, 439; idem, Die Pulverwaffe (as n. 4), p. 33 .

165 NKRSME II (as n. 29), p. 3 I; Stępiński, Żabiński, Strzyż (as n. I 8), p. I 83; Szymczak (as n. I9), p. I I 5 ; Świętosławski (as n. ıо), p. 24.

${ }_{166} \mathrm{ABMH}$ (as n. 25), p. 5 I.
} 
bochsenschotczen czu snyden $[\ldots]) .{ }^{167} \mathrm{R}$. Heś says that oak wood due to its hardness was the most commonly used raw material for gun stocks in the town of Görlitz (Pol. Zgorzelec) in Lusatia at the turn of the 14 th and I 5 th centuries ${ }^{168} \mathrm{~A}$ similar opinion on the popularity of oak wood was expressed by J. Szymczak. ${ }^{169}$ In I 4 I 7 , the use of willow wood was mentioned at Marienburg. ${ }^{170}$ This is hardly surprising, as well-dried willow wood is very hard. ${ }^{171}$ Concerning comparative data, it is assumed that the carriage of the Faule Magd from Dresden was made from oak wood. The carriage can be dated to the last third of the I 6 th century, while the cannon itself (a c. $2700 \mathrm{~kg}$ heavy mittelbuchse which is assembled from iron bars and rims) comes perhaps from the late I 4 th-early I 5 th century ${ }^{172}$ In I 4 I 3 in Elbing (Pol. Elblacg) at the Town Hall there were several kinds of buchsenladen: 2 alde laden, 2 grosse nie laden, der gemeinen laden der $\sin 13 .{ }^{173}$ As the inventory of the Town Hall mentions both lead bullet and stone cannonball guns ${ }^{174}$, alde laden and gemeine laden could refer to stocks or stands for both kinds of firearms. On the other hand, it could be proposed that grosse laden were cannon stands or trestles. From I 4 I 4 there are two records of payments of 7 Scot for 7 lotbussenladen in Elbing. ${ }^{175}$ Regrettably, it is hard to say whether these lead bullet guns were handheld firearms or light cannons. In the same year in Elbing a blacksmith named Stregener was paid 3 Ferto vor I buchse czu beslande in dy lade. ${ }^{176}$ The sum suggests that this gun was a cannon. In I 4 I 5, carpenters at Marienburg (Pol. Malbork) made a special chamber in the Karwan (i.e., a storehouse of wagons and related equipment) to store bochsenladen there. ${ }^{177}$ From the same year there is also a men-

${ }_{167} \mathrm{ABMH}$ (as n. 25), p. 176; Rathgen, Das Geschütz (as n. 4), p. 42 I; idem, Die Pulverwaffe (as n. 4), p. 57 .

168 Heś (as n. 97), p. I 40.

169 Szymczak (as n. 19), p. 96.

${ }_{170} \mathrm{ABMH}$ (as n. 25), p. 278.

${ }_{171}$ Chodyński, Magazyny broni (as n. I I), p. I 89.

${ }_{172}$ O. Baarmann, Die 'Faule Magd' der Königlichen Arsenalsammlung zu Dresden, Zeitschrift für Historische Waffenkunde 4 (1906-1908), pp. 232, 234.

${ }_{173}$ Elbinger Kriegsbuch, ed. M. Toeppen (henceforth: EK), Altpreussische Monatschrift 36 ( I 889), p. 254; Szymczak (as n. I 9), p. I I 4; Chodyński, Inwentarz broni (as n. I I), pp. 75, 78; idem, The stores of arms (as n. I I), pp. 20, 22; Rathgen, Das Geschütz (as n. 4), p. 430; idem, Die Pulverwaffe (as n. 4), p. 72.

${ }_{174}$ EK (as n. 173), p. 253; see also Chodyński, Inwentarz broni (as n. I I), pp. 74-75, 77-78; idem, The stores of arms (as n. I I), pp. $20,22$.

${ }_{175}$ EK (as n. 173), p. 260; NKRSME II (as n. 29), p. 79; Świętosławski (as n. Io), p. 24.

${ }^{176}$ NKRSME II (as n. 29), pp. 94-95.

${ }_{177}$ ABMH (as n. 25), pp. 170-171; Jóźwiak, Trupinda (as n. 14), p. 406; for the Karwan see e.g. Dąbrowska, Proces odlewania dziat (as n. I 5), pp. 2 I, 40; eadem, Badania archeologiczno-architektoniczne (as n. I 5), p. 303; Jóźwiak, Trupinda (as n. I4), pp. 404-408; Nowakowski, 
tion on wood stores for bochsenladen at the Order's capital castle. ${ }^{178}$ In I 417, some sort of a wooden structure to store bochsenladen was mentioned in the Karwan at Marienburg (vor 80 elen holcz czu snyden czu dem schuwer im karwan czu den bochsenladen). ${ }^{179}$

Another term which is not always clear is stel or stelle. From 1420 comes a mention of stele for guns at the Order's capital castle. 0.5 Mark i I Scot and 6 Denars were paid for such stocks for 29 guns. ${ }^{180}$ In this case a rather low price per item (24 Denars) and the number of requested items suggest that the stele were rods or shafts, round or polyhedric in cross-section, which were either inserted in sockets at the breech parts of guns, or on which hand-held firearms were fitted. The term bossenstile or bostilen also appears in accounts of Trier from the $1370 \mathrm{~s}^{181}$ In this case, however, nails for these stile were also bought, which implies that these were rather more complex stands for heavier guns. ${ }^{182}$

In some cases it seems impossible to decide whether stele were stocks for handheld firearms or cannon stands or trestles. This is the case, e.g., with numerous records from the early $15^{\text {th }}$ century from Elbing (Pol. Elblagg). ${ }^{183}$ On the other hand, this term could also be used for artillery trestles. In I4II, 4 Scot and I 2 Denars were paid for carrying a large gun with its trestle to the Town Hall (de grotte bussen up dat Rathus to bringen mit dem stellen). ${ }^{184}$ In I4I 3 at the Town Hall of Elbing there were i I buchsengestelle. Interestingly, this record, mentioning various kinds of gun stocks and trestles, commenced with a statement: Hie volgen dy buchsenladen in deme gwanthuse. ${ }^{185}$ This is another piece of evidence suggesting that the term laden may have been used in a very broad sense. In I 4 I 4 at Marienburg (Malbork) 2 Marks and 0.5 Ferto was paid to 5 carpenters who made laden und gestelle czu den bochsen [...] in dem fyrmaniengarthe und gestelle uff dy

Arsenat zamku (as n. 7), p. 226; S. Ekdahl, The Strategic Organization of the Teutonic Order in Prussia and Livonia, in: La commanderie, institution des ordres militaires dans l'occident médiéval, ed. A. Luttrell, L. Pressouyre (Archéologie et d'histoire de l'art I4), Paris 2002, pp. 23 I, 236.

${ }_{178} \mathrm{ABMH}$ (as n. 25), p. 173.

$179 \mathrm{ABMH}$ (as n. 25), p. 27 I; Jóźwiak, Trupinda (as n. 14), p. 406.

${ }_{180} \mathrm{ABMH}$ (as n. 25), p. 357.

${ }^{181}$ Rathgen, Das Geschütz (as n. 4), p. 175.

${ }_{182}$ B. Rathgen supposes that the terms stele and gestelle were used interchangeably, see Rathgen, Das Geschütz (as n. 4), p. 439; and idem, Die Pulverwaffe (as n. 4), p. 87.

${ }_{183}$ NKRSME I (as n. 29), pp. I 6, 2 I, 229-230; NKRSME II (as n. 29), p. 3 I; Stępiński, Żabiński, Strzyż (as n. I 8), p. I 83; Rathgen, Das Geschütz (as n. 4), p. 427; idem, Die Pulverwaffe (as n. 4), pp. 67-7I.

${ }_{184}$ NKRSME II (as n. 29), p. 3 I ; Chodyński, Inwentarz broni (as n. I I), p. 72; idem, The stores of arms (as n. II), p. I7,

${ }_{185}$ EK (as n. 173), p. 254; Szymczak (as n. 19), p. I I4; Chodyński, Inwentarz broni (as n. I I), pp. 75, 77-78; Chodyński, The stores of arms (as n. I I), pp. 20, 22. 
bolwerk. ${ }^{186}$ This mention says that these gestelle were to be placed on the castle's fortifications, which obviously implies some kind of stands or trestles. Furthermore, in 14 I 4 in Elbing a payment for buchsenstelle was recorded. ${ }^{187}$ This mention was preceded with a record of payment made by the town to Danzig (Pol. Gdańsk) for one large gun which weighed I 2.5 Zentners (i.e., over $590 \mathrm{~kg}$ ), 7 stone cannonball guns, Io large and I 3 small lead bullet guns. ${ }^{188}$ This may imply that at least some of these buchsenstelle were artillery stands or trestles. Furthermore, in I 4 I 7 at Marienburg (Pol. Malbork) an apprentice (geselle) was paid 6 Scot and 20 Denars for 5 days of work zcum buchsengestelle. ${ }^{89}$ Even more (2 I Scot and io Denars) was paid in the same year at the capital castle to Peter Wegener and his three companions for work am buchsengestelle. ${ }^{190}$ Interestingly, some of these records mention the participation of a catapult master (blydenmister) Hannus in the construction of these trestles. ${ }^{191}$ This is of no surprise bearing in mind possible technical similarities in structures of siege engine and artillery stands. 3 gestellen were also recorded in $\mathrm{I} 42 \mathrm{I}$ in the inventory of the Commandery of Nessau (Pol. Wielka Nieszawka). ${ }^{192}$ As these were mentioned separately (the inventory listed both cannons and hand-held firearms), it can be assumed that these gestellen were cannon trestles.

There are also records which clearly refer to artillery stands or trestles. In I 4 I 4 at Marienburg (Pol. Malbork), the manufacture of laden und gestelle czu den bochsen was mentioned. ${ }^{193}$ In the same year and location there were works on stonunge unde loger czu den bochsen. ${ }^{194}$ In I 4 I 5 at Marienburg it was recorded that Io men from a nearby village of Blumenstein (Pol. Kwietniewo) spent one day on processing wooden logs for a gun stand with files (dy eynen tag dy ronen czu bocbsenlade flyeten). ${ }^{195}$ The number of men may imply a considerable size of this structure. In 1419 at Marienburg i 4 Scot was paid to 2 carpenters who worked on axles for buchsenladen ( 4 Scot czu arbeiten 2 czimmerluten an den achsen czu den buchsenladen). ${ }^{196}$ It this case it can be naturally supposed that wheeled carriages were meant.

\footnotetext{
${ }_{186} \mathrm{ABMH}$ (as n. 25), p. I 37.

${ }_{187} \mathrm{EK}$ (as n. I73), p. 260; NKRSME II (as n. 29), p. 79.

${ }_{188}$ NKRSME II (as n. 29), p. 78.

${ }_{189} \mathrm{ABMH}$ (as n. 25), p. 269; Żabiński, Ways of acquisition (as n. 17), pp. I 29-1 30.

${ }_{190} \mathrm{ABMH}$ (as n. 25), p. 269; for other similar expenses see ibidem, pp. 27 1, 278-279, 327-329.

I91 ABMH (as n. 25), pp. 269, 278, 300-301, 305; Jóźwiak, Trupinda (as n. I 4), p. 4 I 6.

${ }_{192}$ GÄDO (as n. 26), p. 482; Stępiński, Żabiński, Strzyż (as n. ı 8), p. 177.

$193 \mathrm{AMBH}$ (as n. 25), p. 137.

${ }_{194} \mathrm{ABMH}$ (as n. 25), p. 148.

i9s $\mathrm{ABMH}$ (as n. 25), p. 193.

${ }_{196} \mathrm{ABMH}$ (as n. 25), p. 327.
} 
A special attention is required for the famous Teutonic heavy cannon - the Grose Bochse from the end of the first decade of the i 5 th century. This gun in all probability weighed over $\mathrm{I} 3$ tons and it was a veuglaire. It was no doubt mounted in an immobile wooden bed (fig. 25). Sources mention a bock associated with this cannon, which may imply an immobile stand or trestle. ${ }^{197}$ In I 408 a smith Swenkenfeld was paid for nails of various size which were to be used for this gun's stand (I2 grosse clinkennagel und 24 cleyner nagel zum bocke zur grossen bochsen). ${ }^{198}$ Furthermore, 3 Ferto was paid to a rope-maker for a harness (gezoume zur grossen bochsen dem seyler). ${ }^{199}$ In the following year, two ropes and two "short pieces" were bought for the trestle ( 2 lynen $[\ldots]$ und $[\ldots]$... 2 korze stocke $z$ u dem bocken). ${ }^{200}$ Of interest is another record from I 409, mentioning a payment of 7.5 Marks and 7 Scot for casting of $I 2$ erynne schywen [...] zu dem bocke zur grosen bochsen. ${ }^{201}$ These bronze schywen were in all probability pulleys or drums. B. Rathgen supposes that these pulleys and the bock were part of an lifting device or crane, which was used for placing the gun on its transportation wagon. ${ }^{202}$ R. D. Smith and $\mathrm{K}$. DeVries say that large bombards which were transported on carts were usually provided with some kind of lifting devices ${ }^{203}$ (fig. 26). Pulleys are also known from other records. In I 4 I 2 at Marienburg (Pol. Malbork) 24 Denars was spent on $c z u$ buchzen 2 schyben ${ }^{204}$, while in the following year a pair of such devices was purchased for I Scot 2 Denars. ${ }^{205}$ While B. Rathgen's proposal seems to be perfectly sound, it could be also assumed that - in combination with the afore-mentioned ropes - such pulleys or drums may have been part of a system used to move the gunpowder chamber backwards and forwards in order to first charge it and then secure it back to the chase. This assumption is partially confirmed by another mention from I 409. It says about a payment of 3 Marks and I Ferto for 4 hemp ropes weighing 12 stones for the heavy cannon (vor 4 lynen dy haben I 2 steyne hanf

197 Bock zu der grosser busen was also mentioned in Trier in I 375-1 376, see Rathgen, Das Geschütz (as n. 4), pp. 175-176, I80.

${ }_{198}$ MTB (as n. 23), p. 5 I 5 ; Żabiński, The Grose bochse (as n. 17), p. 35, tab. 3.

199 MTB (as n. 23), p. 5 I I; Żabiński, The Grose bochse (as n. 17), p. 35, tab. 3; Schmidtchen (as n. 6), p. 70; Rathgen, Das Geschütz (as n. 4), p. 406; idem, Die Pulverwaffe (as n. 4), p. 28.

${ }^{200}$ MTB (as n. 23), p. 525 ; Rathgen, Das Geschütz (as n. 4), p. 406; idem, Die Pulverwaffe (as n. 4), p. 28.

${ }^{201}$ MTB (as n. 23), p. 558; Żabiński, Die Grose bochse (as n. 17), p. 35, Tab. 3; Rathgen, Das Geschütz (as n. 4), p. 406, 441; idem, Die Pulverwaffe (as n. 4), p. 29; on these expenses see also Toeppen (as n. I), p. 234-235.

${ }^{202}$ Rathgen, Das Geschütz (as n. 4), p. 44I; idem, Die Pulverwaffe (as n. 4), pp. 90-91.

${ }_{203}$ Smith, DeVries (as n. 53), pp. 204, 207-208, 256; see also Szymczak (as n. 19), p. 7 I.

${ }^{204} \mathrm{ABMH}$ (as n. 25), p. 75.

205 $\mathrm{ABMH}($ as n. 25), p. I 13. 
[...] zur grosen bochsen). I Mark was paid for 4 short straps, used to span the gun together (vor 4 korze stroppen do mete man dy grose bochse zu samne spennet). Furthermore, another 8 straps were purchased for 2 Marks. Out of these, 2 went for the heavy cannon and 4 for another new gun (vor 8 stroppen, 2 zur grosten bochsen und 4 zur nuwen bochsen). ${ }^{206}$ Another record from 1409 says that the stand or crane was made again and fitted again with iron (vor den bog weder zu machen $[. .$. den bok weder zu beslohen). Furthermore, I.5 Mark was paid for fitting the heavy cannon with iron (dy groste buchse zu beslon). ${ }^{207}$ It cannot be excluded that these expenses were somewhat related to the use of the heavy cannon in siege warfare in the initial part of the war against Kingdom of Poland in August I 409. The same could be supposed about a brace or clamp to the gun stand or crane (cloben zum bochsenbocke). ${ }^{208}$ It is possible that the payment of House Commander of Thorn (Pol. Toruń) for oak wood and spruce or fir logs to be used for a gun stand is also related to the Teutonic Order's heavy cannon. ${ }^{209}$

Data on wheeled carriages as such is not very numerous. Apart from records which were discussed above, attention is also drawn to a mention from I 409 , saying that 3.5 Marks was paid to locksmiths for fitting gun carriages with iron (3.5 Mark den cleynsmeden vor dy karren $z$ u den bochsen $z u$ beslohen, yo vor eyner 0.5 Mark). ${ }^{210}$ It is difficult, however, to determine whether these fittings were designed for carriages themselves or for their wheels (as shown below, there are numerous records of fitting wheels for gun wagons with iron). Furthermore, in I 4 I 4 in Elbing (Pol. Elbląg) harness-makers (schirmecher) were paid i 4 Scot for 2 "wagon trestles" for large guns (wagengestelle $z u$ den grosen bussen). ${ }^{21}$ These wagengestelle may have been some sort of early wheeled carriages for heavy artillery. On the other hand, W. Świętosławski proposes that this term may refer to wooden frameworks of artillery wagons. ${ }^{212}$

${ }^{206}$ MTB (as n. 23), p. 574; Żabiński, The Grose bochse (as n. 17), p. 35, tab. 3; Rathgen, Das Geschütz (as n. 4), pp. 407, 44 I; idem, Die Pulverwaffe (as n. 4), pp. 32, 46.

${ }_{207}$ MTB (as n. 23), p. 597; Żabiński, Die Grose bochse (as n. 17), p. 35, tab. 3; Rathgen, Das Geschütz (as n. 4), pp. 408-409; idem, Die Pulverwaffe (as n. 4), p. 33.

${ }^{208}$ MTB (as n. 23), p. 597; Żabiński, Ways of acquisition (as n. 17), p. I 37; idem, Die Grose bochse (as n. 17), p. 37-39.

${ }^{209}$ MTB (as n. 23), p. 597; for the expenses on the Grose Bochse's stand see also Engel, Nachrichten über Waffen (as n. 3), p. 23 I.

${ }_{210}$ MTB (as n. 23), p. 573; Rathgen, Das Geschütz (as n. 4), pp. 407, 420; idem, Die Pulverwaffe (as n. 4), p. 30 ; Engel, Nachrichten über Waffen (as n. 3), p. 23 I.

${ }^{211}$ NKRSME II (as n. 29), p. 84; Żabiński, Ways of acquisition (as n. 17), pp. 133-1 34; Szymczak (as n. I 9), p. I I 4; Rathgen, Das Geschütz (as n. 4), p. 429; idem, Die Pulverwaffe (as n. 4), p. 7 I; Chodyński, Inwentarz broni (as n. I I), p. 72; idem, The stores of arms (as n. I I), p. I 7.

212 Świętosławski (as n. I0), p. 24. 
An interesting piece of information is known from 1409 from the Order's capital castle. In this year 0.5 Mark was paid to a locksmith who fitted a caisson with iron. This caisson was used to transport gun equipment (eyme cleynsmede der eynen kommen beslog, dor inne man bochsengerete furte). ${ }^{213}$

There are also several records mentioning wheels for guns. In I 394 at Marienburg (Pol. Malbork) there were 22 wheels for a large gun (grose buchse). I o of these were fitted with iron (beslagene rade) and I 2 were not. ${ }^{214}$ It would be interesting to know whether these 12 wheels were supposed to be fitted with iron in the future or both kinds were to be used, e.g., depending on terrain conditions. Prices of gun wheels varied. In I 409 at Marienburg (Pol. Malbork) I Mark was paid for 24 small wheels for gun carriages (cleyne rade $z u$ bochsenkarren zu machen). ${ }^{215}$ In the same year, a comparable sum of 3 Ferto was paid for 4 large gun wheels and I wheel for a gun carriage (Hannos Hoffeman dem rademecher vor 4 grose bochsenrade und vor I rat zum bochsenkarren). ${ }^{216}$ Also in 14095 Scot was spent on 4 wheels for gun carriages (rade $z u$ bochsenkarren). ${ }^{217}$ On the other hand, in 14176 Marks went for 24 wheels for gun carriages (Urban dem rademacher von Dirssaw vor 24 rade czu bochsenkarren). ${ }^{218}$ It could be asked whether the size of these wheels was the only factor to make them six times more expensive than the 24 small wheels from I 409. In I 4 I 9 at Marienburg (Pol. Malbork), 30 gun wheels were manufactured for the price of 3 Marks and 0.5 Ferto. ${ }^{219}$ Furthermore, there are also mentions of iron rims used to fit gun wheels with. In 4066 in Elbing (Pol. Elbląg) 4 Marks and 0.5 Ferto was paid for 8 iron bars for guns (ysern schenen vor bussen). ${ }^{220}$ This price seems to be pretty high, as in 14098 Marks and 4 Scot was spent on 2 bundles of bars and 50 large bars for gun wheels (vor 2 gebunt schenen und vor so grose schenen

${ }_{213}$ MTB (as n. 23), p. 574; Stępiński, Żabiński, Strzyż (as n. I 8), p. I75; Rathgen, Das Geschütz (as n. 4), p. 420; idem, Die Pulverwaffe (as n. 4), p. 55 ; Toeppen (as n. I), p. 233.

$214 \mathrm{MÄB}$ (as n. 26), pp. 101-102.

${ }_{215}$ MTB (as n. 23), p. 559; Schmidtchen (as n. 6), p. 70; Rathgen, Das Geschütz (as n. 4), p. 407; idem, Die Pulverwaffe (as n. 4), p. 29; Engel, Nachrichten über Waffen (as n. 3), p. 231.

${ }^{216}$ MTB (as n. 23), p. 559; Schmidtchen (as n. 6), p. 70; Rathgen, Das Geschütz (as n. 4), p. 407; idem, Die Pulverwaffe (as n. 4), p. 30; Engel, Nachrichten über Waffen (as n. 3), p. 23 I.

${ }_{21}$ MTB (as n. 23), p. 580 ; Rathgen, Das Geschütz (as n. 4), p. 408; idem, Die Pulverwaffe (as n. 4), p. 32; Engel, Nachrichten über Waffen (as n. 3), p. 23 I.

${ }_{218}$ ABMH (as n. 25), p. 279; Żabiński, Ways of acquisition (as n. 17), p. I 3 I; Świętosławski (as n. Iо), 1993 , p. 24.

${ }_{219} \mathrm{ABMH}($ as n. 25), p. 328.

${ }^{220}$ NKRSME I (as n. 29), p. 67; Żabiński, Technology of manufacture (as n. 17), p. 89. 
$z u$ bochsenraden). ${ }^{221}$ In I 4 I 0,2 Marks was spent on fitting four gun wheels with iron in Elbing (Elbląg) (4 rade to beslande to den bussen).222

A separate problem are carts and wagons which were solely used for transportation of cannons and were not applied as carriages during the operation of artillery in the field. ${ }^{223}$ Such wagons should not be confused with battle wagons, which were usually equipped with firearms (both hand-held and light cannons), although a distiction between them may have not always been clear. ${ }^{224}$ Furthermore, it cannot be excluded that agricultural carts could be used for transport of lighter guns (and vice versa), as suggested by a record from I 434 concerning a farm in Dristschmin (Pol. Drzycim) near Graudenz (Pol. Grudziądz), which mentions I buchschenwayn. ${ }^{225}$ An opinion that "ordinary" carts were initially used for the transportation of cannons has also been expressed by J. Szymczak. ${ }^{226}$ On the other hand, it seems obvious that special wagons with reinforcing iron fittings must have been used in the case of heavy cannon barrels (fig. 27). As early as 1396 the register of the Karwan at Marienburg (Pol. Malbork) recorded 5 large gun wagons, I 9 wheels with iron rims for such wagons and I 2 wheels with no rims for these (s grose buchsenwayn, Ig beslagene rade czu den buchsenwayn, I2 unbeslagene rade czu denselbin wayn)..$^{27}$ In 1 402, 54 schenen czu bochsenwagen were mentioned. ${ }^{228}$ These were probably iron bars to make rims to fit wagon wheels with. There are also many other mentions of gun wagons and wheels for them; regrettably, in a majority of cases they do not provide more details on their construction. ${ }^{229}$

There are also several more detailed records. In 14092 Scot was paid for 2 hooks (hoken) and 4 geslofe (perhaps reinforced locks) to a gun wagon. ${ }^{230}$ In

${ }^{221}$ MTB (as n. 23), p. 57 I; Schmidtchen (as n. 6), p. 70; Rathgen, Das Geschütz (as n. 4), p. 407; idem, Die Pulverwaffe (as n. 4), p. 30 ; Toeppen (as n. I), p. I 53 ).

${ }^{222}$ NKRSME I (as n. 29), p. 2 I 8.

223 Strzyż, Broń palna (as n. 20), p. I09, fig. I7; Heś (as n. 97), p. I 42; Smith, DeVries (as n. 53), pp. 256-258; Goetz (as n. 76), p. 50; Rathgen, Das Geschütz (as n. 4), pp. 22, 37-38, 270, $277-279$.

${ }^{224}$ On battle wagons see e.g. Strzyż, Broń palna (as n. 20), pp. 162-1 88; McLachlan (as n. 53), pp. 42-45; Szymczak (as n. 19), pp. 317-319; Oakeshott (as n. 53), pp. 36-37; Müller (as n. 77), p. 35; Rathgen, Das Geschütz (as n. 4), p. 60.

$225 \mathrm{GÄDO}$ (as n. 26), p. 619.

${ }_{226}$ Szymczak (as n. I9), p. 213.

${ }_{227} \mathrm{MÄB}$ (as n. 26), pp. 102-103; the same numbers were recorded in I 401 , see MÄB, pp. 103- I04; see also Toeppen (as n. I), pp. I33-1 34, 235.

${ }_{228}^{28} \mathrm{MÄB}$ (as n. 26), p. 142.

$229 \mathrm{ABMH}$ (as n. 25), p. 69; Biskup (as n. 28), p. Io I; GÄDO (as n. 26), pp. 619-620, 622, 766-767; MÄB (as n. 26), pp. 104-105; NKRSME II (as n. 29), p. 95; KT (as n. 3 I), p. 177.

${ }_{230}$ MTB (as n. 23), p. 597; Rathgen, Das Geschütz (as n. 4), p. 409; idem, Die Pulverwaffe (as n. 4), p. 33 . 
I 4 Io in Elbing (Pol. Elbląg) I Mark was paid for iron equipment for a gun wagon (yserwerk to deme bussenwagen). Furthermore, 2 Marks and 4 Scot went for I 4 wagon rims (wagenschenen), 2 shovels (schuffln), 3 spades (spaden), wheel and gun nails (redenegele, bussennagele), as well as 2 ridebloke and traderynken. ${ }^{231}$ In I 4 I 4 in Elbing harness-makers (schirmecher) received 4 Scot for 2 leteren for gun wagons (bussenwagen). ${ }^{232} \mathrm{~B}$. Rathgen interpreted these leteren as ladders ${ }^{233}$, while W. Swiętosławski assumes that this term refers to lanterns for gun wagons. ${ }^{234} \mathrm{On}$ the other hand, iron-fitted ladders as part of gun wagon equipment were mentioned in Elbing in the same year, when I 2 Mark was paid to a smith Vasolt vor dy buchsenwagene unde leyteren czu beslon. ${ }^{235}$ In I 4 i 8 at Marienburg (Pol. Malbork) 6 Marks and 3.5 Ferto was spent on 10 wheels to a gun wagon and I 2 wheels for 3 expedition wagons (reyszeweinen). ${ }^{236}$ One year later 0.5 Mark went for boring of gun wheels (buchsenrade czu boren). ${ }^{237}$ This can suggest that these wheels were made from solid discs of wood, which had to be provided with openings for axles. An example of a I 4 th century Italian cannon with such wheels is given by D. Goetz. These wheels were made from thick logs which were put together along their lengths and were provided with iron rims. ${ }^{238}$ A lock for a gun wagon (slos [...] czu buchsenwaynen) was also mentioned in I 4 I 9. ${ }^{239}$ Furthermore, in I 4 I 4 in Elbing (Pol. Elbląg) 6 Scot and 4 Denars was spent on tallow (talch) used to grease gun wagons and winders. ${ }^{240}$

An interesting description of a wagon can be found in a letter of the Grand Master to Danzig (Pol. Gdańsk) from i 9 April I 433, concerning war preparations agains the Hussites. This description refers to battle wagons (furweyne) and not gun transporting wagons, but there are still several similar points. Such a wagon should be iron-fitted (beslagen), on high wheels with iron rims (mit hogen raden, die beslagen sien) and it should be pulled by $5-6$ good horses. It should be equipped with 2 strong chains, a hoe, a spade and a shovel. ${ }^{241}$

\footnotetext{
${ }^{231}$ NKRSME I (as n. 29), p. 219.

${ }_{232}$ NKRSME II (as n. 29), p. 84; Żabiński, Ways of acquisition (as n. 17), pp. I 33 - 134.

233 Rathgen, Das Geschütz (as n. 4), pp. 429, 439; idem, Die Pulverwaffe (as n. 4), pp. 71, 88.

${ }_{234}$ Świętosławski (as n. Io), p. 24.

235 NKRSME II (as n. 29), p. 95; Żabiński, Ways of acquisition (as n. 17), p. 134; Rathgen, Das Geschütz (as n. 4), pp. 429, 439; idem, Die Pulverwaffe (as n. 4), pp. 71, 88.

${ }_{236} \mathrm{ABMH}$ (as n. 25), p. 3 r 0 ; Żabiński, Ways of acquisition (as n. I 7), p. 13 I.

$237 \mathrm{ABMH}$ (as n. 25), p. 327.

${ }_{238}$ Goetz (as n. 76), p. 37.

${ }_{239} \mathrm{ABMH}$ (as n. 25), p. 33 8; Żabiński, Ways of acquisition (as n. I 7), p. I 3 I.

${ }^{240}$ NKRSME II (as n. 29), p. 8 I ; Rathgen, Das Geschütz (as n. 4), p. 429; idem, Die Pulverwaffe, p. 7 I.

${ }^{241}$ Acten der Ständetage Preussens unter der Herrschaft des Deutschen Ordens, ed. M. Toeppen, 5 vols., Leipzig I 878-1 886, here vol. I, No. 448, p. 593 ; see also Strzyż, Broń palna (as n. 20),
} 
Sometimes it is possible to relate such mentions to specific cannons which are known from sources. In I 409 at Marienburg (Pol. Malbork) i 6 Scot was paid for 4 wheels (rade) to a large gun wagon (groser bochsenwayn) and later on in the same year I Mark was spent on 4 large wheels (grose rade) to a gun wagon. ${ }^{242}$ These records can perhaps be related to the Grose Bochse. Also in 14092 Marks went for making a wagon for this gun. ${ }^{243}$ As these expenses come from the period when the the heavy cannon was in the field during the campaign against Kingdom of Poland, it can be assumed that they testify to a need of frequent repairs or replacements. It is hardly suprising that wheels of the wagon used to transport such a heavy cannon were especially vulnerable to damages. Another record from I 409 mentions luse lonen zum grosen bochsenwayn $e^{244}$, which were perhaps some sort of movable shutters (fig. 28). Also in I 409 2.5 Marks was paid for iron fittings for a wagon for the long gun cast in Danzig (Pol. Gdańsk) (vor I wayn zu beslohen zu der langen bochsen dy zu Danczk gegossen wart).245

A necessary part of gun or wagon constructions were iron fittings. ${ }^{246}$ Apart from mentions concerning fittings of specified types of stands, trestles, carriages and wagons there are also some more general ones. In I 403 at Marienburg (Pol. Malbork) I 7 guns which were to be sent to Ragnit (Russ. Neman) were iron-fitted. ${ }^{247}$ Two years thereafter at Königsberg (Russ. Kaliningrad) 3 Marks and I 3 Scot was paid for 6 stones of iron for gun equipment and other tools $(z u$ dem buchsengezoy und vor alle gerethe dorzu). ${ }^{248}$ In 1409 at the Order's capital castle a smith Jauwernig was paid I Mark for fitting 4 small guns with iron (vor 4 cleyne bochsen zu beslohen). ${ }^{249}$

p. I 66; and D. Heckmann, Kriegstechnische Innovationen in den mittelalterlichen Deutschordenslanden Preussen und Livland, Militärgeschichtliche Zeitschrift 65 (2006), p. I 27.

${ }^{242}$ MTB (as n. 23), pp. 555, 559; Żabiński, The Grose bochse (as n. 17), p. 35, tab. 3; Schmidtchen (as n. 6), p. 70; Rathgen, Das Geschütz (as n. 4), p. 407.

${ }_{243}$ MTB (as n. 23), p. 577; Żabiński, The Grose bochse (as n. 17), p. 35, tab. 3; Rathgen, Das Geschütz (as n. 4), p. 408; Toeppen (as n. I), p. 158.

${ }^{244}$ MTB (as n. 23), p. 579; Rathgen, Das Geschütz (as n. 4), p. 408, and idem, Die Pulverwaffe (as n. 4), p. 3 I, he says that these were Spannägel or large nails; Żabiński, Ways of acquisition (as n. 17), p. 130; idem, The Grose bochse (as n. 17), p. 35, tab. 3; Toeppen (as n. I), p. 235.

${ }_{245}$ MTB (as n. 23), p. 573; Żabiński, Ways of acquisition (as n. 17), p. I 3 I; Rathgen, Das Geschütz (as n. 4), p. 407; idem, Die Pulverwaffe (as n. 4), p. 30; Engel, Nachrichten über Waffen (as n. 3), p. 23 I f for other cases of wagons for heavy bombards see e.g. Serdon-Provost (as n. I 36), p. 192.

${ }^{246}$ For comparative data see e.g. Heś (as n. 97), pp. I 39-1 40; Rathgen, Das Geschütz (as n. 4), p. I 5. 247 MTB (as n. 23), p. 247.

${ }_{248}$ MTB (as n. 23), p. 364; Engel, Nachrichten über Waffen (as n. 3), p. 232.

${ }_{249}$ MTB (as n. 23), p. 573; Rathgen, Das Geschütz (as n. 4), pp. 408, 420; idem, Die Pulverwaffe (as n. 4), p. 30; Engel, Nachrichten über Waffen (as n. 3), 1897-1899, p. 231. 
As mentioned above while discussing the stand of the Grose Bochse, ropes of all kind were indispensable part of gun equipment. However, mentions of such ropes are rather rare in sources. In 1408 at the Order's capital castle 2 Marks was paid to a rope-maker for making 2 ropes for guns (dem seyler of rechenschaft of 2 lynen zu machen zur bochsen). ${ }^{250}$ In the following year, 3 Marks and 8 Scot was spent on I o stones of rope yarn, to be used for throwing engine ropes, gun straps and other ropes (vor Io steyne kabelgarn zu blydenlynen und bochsenstroppen und lyne). ${ }^{251}$ About 1523 at Königsberg (Russ. Kaliningrad) I 22 syllen were recorded. ${ }^{252}$ In all probability these were ropes used for wagon harness. A somewhat analogous role may have been played by chains, which are also sporadically mentioned. A gun chain was recorded in $\mathrm{I} 432$ in the Karwan at Marienburg (Pol. Malbork). Interestingly, it was stated that it was used to chain prisoners (I kete von I 2 buchsen do man die gefangen ane snirt). ${ }^{253}$ From I 52 I there comes a mention of I half-serpentine with a chain (I halbe schlange I ketten dorczu) at (Preußisch) Eylau (Russ. Bagrationovsk). ${ }^{254}$ Furthermore, the list of the Order's firearms from c. I 523 records I 84 chains (ketten) at Königsberg (Russ. Kaliningrad). ${ }^{255}$

Another problem are horse teams used for wagons and carriages with individual types of guns. On the basis of data concerning the participation of the Grose Bochse in the campaign against Kingdom of Poland in 1409 it can be said that a team of merely 8 horses was used for the transportation of this heavy cannon, which weighed perhaps more than I 3 tons. This implies a load of c. I.7 ton per horse (or c. $840 \mathrm{~kg}$, in case each part of the gun was transported separately and their weight was more or less similar). On the other hand, the main part of the travel in all probability occurred by water, as unloading of the cannon from the ship was mentioned. Therefore, horses perhaps drew the gun wagon for very short distances only (e.g., from the ship to the gun post). ${ }^{256}$ In Maximilian I's propaganda paintings, the wagon with the Lew (heavy siege cannon, mounted on an immovable stand) is drawn by a team of I 5 horses. Maximilian's inventory sources mention teams of i 8 horses for heavy scharfmetzen and those of 6 horses form smaller scharfmatzen. ${ }^{257}$ The issue of transportation of cannons has also been thor-

\footnotetext{
${ }_{250}$ MTB (as n. 23), p. 5 I I ; Żabiński, Ways of acquisition (as n. I 7), p. I 3 I.

${ }_{251}$ MTB (as n. 23), p. 590 ; Rathgen, Das Geschütz (as n. 4), p. 408.

252 Biskup (as n. 28), p. Iо I.

$253 \mathrm{MÄB}$ (as n. 26), p. 109- I 10.

254 GÄDO (as n. 26), p. 177.

255 Biskup (as n. 28), p. Iо I.

${ }_{256}$ MTB (as n. 23), pp. 557-578; Żabiński, Ways of acquisition (as n. 1 7), p. I 37; idem, The Grose bochse (as n. 17), pp. 38-39, tab. 5.

257 Chodyński, Habsburg artillery (as n. I I), p. 58.
} 
oughly discussed by J. Szymczak. This scholar assumes that a team of I 2 horses was needed to draw the wagon of a 2.5 ton cannon, while another 16 horses were needed for the wagon which transported the cannon's stand. In 1467 in Silesia, a team of 24 horses pulled the wagon with the barrel of a c. 4 ton cannon. ${ }^{258}$

\section{Gun equipment}

Data on gun equipment of various kinds (fig. 29) occurs quite frequently in sources. The first category which can be isolated are general mentions, which simply state the very presence of such tools. In some cases it is stated that the equipment is stored in a given room or a container. As mentioned above, a purchase of iron for making gun equipment and other tools for firearms was recorded at Königsberg (Russ. Kaliningrad) in I $405 .{ }^{259}$ In I 413 at the Order's capital castle a payment of I Mark to a master gunner (bochszenschutcz) Hartman was made. Interestingly, the money was taken by a local hospitaller (spitteler), who bought equipment (gerethe) for the artilleryman. ${ }^{260}$ In the same year various gun tools stored in small chests (kleine kysten, do der buchsen gerethe mancherleye inne is) were recorded in the Town Hall in Elbing (Pol. Elbląg). ${ }^{261}$ Three years thereafter a Teutonic Order's inventory of the local commandery mentioned I medium-sized stone cannonball gun with all the equipment (I mittelmessige steynbuchze mit allen czugehorungen). ${ }^{262}$ A similar record is known from 1508 concerning Teutonic weaponry stores at Angerburg (Pol. Węgorzewo), where 2 veuglaires with all the equipment (vogeler mit aller zugehor) were mentioned. ${ }^{263}$ In 1417 I Mark was paid at Marienburg (Pol. Malbork) to 3 carpenters for a week of works on a gun equipment chamber in the Karwan (czu der kamer im karwan czu bochsengerethe). ${ }^{264}$

The first action in preparing the gun to fire was to put the gunpowder into the barrel. ${ }^{265}$ This was done using ladles, which were sometimes fitted with metal. In

\footnotetext{
${ }_{258}$ Szymczak (as n. I9), pp. 2 1 5-230, tab. I 2; see also A. Bołdyrew, Equus Polonus. Koń w wojsku polskim w XVI wieku, Piotrków Trybunalski 2016, pp. I 30-139, who assumes a "normal" load of c. $200 \mathrm{~kg}$ per horse for longer distances.

${ }_{259} \mathrm{MTB}$ (as n. 23), p. 364.

${ }^{260} \mathrm{ABMH}$ (as n. 25), p. I I 3; Jóźwiak, Trupinda (as n. I 4), p. 434.

${ }^{261}$ EK (as n. I73), p. 254; see also Chodyński, Inwentarz broni (as n. I I), pp. 75, 77-78; idem, The stores of arms (as n. I I), pp. 20, 22).

${ }^{262}$ GÄDO (as n. 26), p. 86.

${ }^{263} \mathrm{GÄDO}$ (as n. 26), p. 7.

${ }^{264} \mathrm{ABMH}$ (as n. 25), p. 268; Żabiński, Ways of acquisition (as n. I 7), p. 130.

${ }^{265}$ On individual stages of gun firing see also e.g. Szymczak (as n. 19), pp. 73-75; Goetz (as n. 76), pp. 64-65; Schmidtchen (as n. 6), pp. I 5-i 8, figs. 4-6.
} 
I 409 at Marienburg (Pol. Malbork) the smith Jauwernig made 5 charging ladles (ladeleffel) for the Grose Bochse. ${ }^{266}$ In the same year 2 Scot was paid for a metal sheet for a ladle to the heavy cannon (blech zum ladeleffer zur grosten bochsen). ${ }^{267}$ This sum was perhaps a half of the price for a complete ladle, as suggested by a mention from I 4 I 4 from Elbing (Pol. Elbląg), where the smith Vasolt received 8 Scots for 2 powder ladles for large guns (2 pulverleven czu den grosen buchsen). ${ }^{268}$ Apart from that, ladeschuffeln or pulverschuffeln are also sometimes mentioned in inventory sources, usually with no further details of their construction. ${ }^{269}$ A very interesting record is known from 1414 from Elbing (Pol. Elblagg) and it mentions a payment of 4 Scot for 2 pipes for gunpowder ( 2 roren, do man das pulver mete intut)..$^{270}$

After the gun had been charged with gunpowder, a wooden stopper was inserted into the barrel. Its role was to secure additional tightness and prevent combustion gases from escaping. ${ }^{271}$ According to Johannes Bengedans, a mid- I 5 th century German master gunner (who also spent some time in the Order's service), such a stopper (proff) was to be wrapped in a piece of cloth (tuch). ${ }^{272}$ Interestingly, 2 ells of fustian (2 elen parcham) were bought for 0.5 Ferto at Königsberg (Russ. Kaliningrad) in 1405 , with a mention that master gunners needed it for firearms (die die buchsenschuczen zum fuyrgeschos haben wolden). ${ }^{273}$ Prices of stoppers varied, according to the size of gun they were meant for. In I 405 at Königsberg I 3 Scot was paid for 100 gun stoppers (pfroppen zu den buchsen). ${ }^{274} \mathrm{~A}$ variety of

${ }^{266}$ MTB (as n. 23), p. 573; Żabiński, The Grose bochse (as n. 17), p. 35 , tab. 3.

${ }^{267}$ MTB (as n. 23), p. 597; Stępiński, Żabiński, Strzyż (as n. 18), p. 175; Żabiński, The Grose bochse (as n. 17), p. 35, tab. 3; Schmidtchen (as n. 6), p. 7 I; Rathgen, Das Geschütz (as n. 4), pp. 407-408; idem, Die Pulverwaffe (as n. 4), pp. 30, 33; Engel, Nachrichten über Waffen (as n. 3), p. 232; Toeppen (as n. I), p. 23 I.

${ }^{268}$ NKRSME II (as n. 29), p. 95; Chodyński, Inwentarz broni (as n. I I), p. 73; idem, The stores of arms (as n. I I), p. I8; Rathgen, Das Geschütz (as n. 4), p. 429; idem, Die Pulverwaffe (as n. 4), p. 7 I.

${ }^{269}$ GÄDO (as n. 26), pp. I 42, 204, 544; 620, 622; MÄB (as n. 26), pp. 19-20, 22-24; Stępiński, Żabiński, Strzyż (as n. ı 8), p. ı 80.

${ }_{270}$ NKRSME II (as n. 29), p. 95.

${ }^{271}$ On such stoppers see e.g. Heś (as n. 97), p. I 40; Smith, DeVries (as n. 53), p. 258 ; Szymczak (as n. I9), pp. 73-75, I I9-I 20; Oakeshott (as n. 53), p. 32; Müller (as n. 77), p. I 8; Rathgen, Das Geschütz (as n. 4), pp. I 8, I 22, 203, 48 I; Baltzer (as n. 2), p. 22; see also Jakubowski (as n. 44), pp. 406, 4 II .

${ }_{272}$ Bengedans (as n. 40), chapter 34, p. 50; see also Rathgen, Das Geschütz (as n. 4), p. 203.

${ }_{273}$ MTB (as n. 23), p. 364; Rathgen, Das Geschütz (as n. 4), p. 404; idem, Die Pulverwaffe (as n. 4), p. 25; Engel, Nachrichten über Waffen (as n. 3), p. 232.

${ }^{274}$ MTB (as n. 23), p. 364; Schmidtchen (as n. 6), p. 72; Rathgen, Das Geschütz (as n. 4), p. 404; idem, Die Pulverwaffe (as n. 4), p. 25. 
stoppers was recorded four years thereafter at Marienburg (Pol. Malbork). I Mark and 108 Denars was paid for fitting 23 stoppers for the large gun (perhaps the Grose Bochse) with rings on both ends, which gives 36 Denars per item. Interestingly, only 8 Scot was paid for 2 I stoppers for the largest gun. I Mark was paid for turning 180 stoppers for old large guns (proppe zu drehen zu den alden grosen bochsen). The price of 120 stoppers for medium-sized guns was 0.5 Mark, while I Ferto was paid for 420 stoppers for small stone cannonball guns on wheeled carriages. ${ }^{275}$ Another detailed record is also known from I 409. I Mark io Scot and 20 Denars was paid for 5 large stoppers for the largest gun and more than 60 for the second largest one. The price of these largest stoppers was 8 Denars per item. I 20 stoppers for another large cannon called the "Wall-Breaker" (Vellemuwer) were also bought and their cost was 4 Denars per item. Furthermore, there were 60 stoppers for an Osterode (Pol. Ostróda) gun and 30 stoppers for a medium-sized Graudenz (Pol. Grudziądz) gun. Their respective prices were 3 and 2 Denars per item. Eventually, I Ferto was paid for fitting 5 large stoppers with rings on both ends. ${ }^{276}$ Gun stoppers are also sporadically mentioned in inventory sources. ${ }^{277}$ Furthermore, records from 1423 and 1424 concerning Schwetz (Pol. Świecie) and I 413 and 1428 for Elbing (Pol. Elbląg) mention pfropeysen ${ }^{278}$, which may have been iron fittings for stoppers. Eventually, it is possible that a pulverklocz, recorded in $\mathrm{I}_{4} \mathrm{I} 3$ in the inventory of the Town Hall of Elbing ${ }^{279}$, was also a kind of stopper. On the other hand, A. R. Chodyński states that it was rather a ramrod. ${ }^{280}$ Yet another opinion was expressed by J. Szymczak who interpreted this device as a gunpowder pounder. ${ }^{281}$

Projectiles were inserted into barrels using ramrods. These tools were also used

${ }_{275}$ MTB (as n. 23), p. 573; Żabiński, The Grose bochse (as n. 17), p. 35, Tab. 3; Świętosławski (as n. Io), p. 26; Schmidtchen (as n. 6), p. 72; Rathgen, Das Geschütz (as n. 4), pp. 407, 41 3; idem, Die Pulverwaffe (as n. 4), pp. 3 I, 4 I.

${ }_{276}$ MTB (as n. 23), pp. 589, 597; Stępiński, Żabiński, Strzyż (as n. I 8), pp. 174-175; Żabiński, The Grose bochse (as n. 17), p. 35, tab. 3; for stoppers see also Rathgen, Das Geschütz (as n. 4), pp. 408-409, 4I 3; idem, Die Pulverwaffe (as n. 4), p. 32; Engel, Nachrichten über Waffen (as n. 3), p. 232; Toeppen (as n. I), pp. I 59, 233.

277 EK (as n. I73), p. 253; see also Chodyński, Inwentarz broni (as n. I I ), pp. 74, 77-78; idem, The stores of arms (as n. I I), pp. 20, 22; GÄDO (as n. 26), p. 656.

${ }^{278}$ GÄDO (as n. 26), pp. 88, 620, 622; EK (as n. 173), p. 253; see also Chodyński, Inwentarz broni (as n. I I), pp. 74, 77-78; Chodyński, The stores of arms (as n. I I), pp. 20, 22; Stępiński, Żabiński, Strzyż (as n. 1 8), p. I 80.

279 EK (as n. 173), pp. 253-254; see also Chodyński, Inwentarz broni (as n. I I), pp. 77-78; idem, The stores of arms (as n. I I), p. 22; Rathgen, Das Geschütz (as n. 4), p. 430 ; idem, Die Pulverwaffe (as n. 4), p. 72.

${ }^{280}$ Chodyński, Inwentarz broni (as n. I I), p. 75; idem, The stores of arms (as n. I I), p. 20.

${ }^{281}$ Szymczak (as n. 19), p. 76. 
to clean barrels after the gun had been fired. Ramrods (stempel) are sometimes mentioned in Order's inventories, but in most cases with no additional details on their construction or function (e.g., ramrods for cannons and for hand-held firearms). ${ }^{282}$ Sporadically, more information is offered. In I 4 I 4 in Elbing (Pol. Elbląg) a price of 48 Denars was paid for 2 ramrods. ${ }^{283}$ In 1434 at Graudenz (Pol. Grudziądz) 2 iron ramrods (eysern stempel) were recorded. ${ }^{284}$ It is difficult, however, to determine whether this meant all-iron tools (rather heavy and thus not very practical), or, more probably, wooden ramrods with iron fittings. The use of ramrods made entirely from iron can be suggested by a record from 1434 from Christburg (Pol. Dzierzgoń), which mentions i ladeyszen. ${ }^{285}$ Furthermore, there are several mentions of iron rods (yserynne/eysern stangen) in Teutonic Order's inventories in the context of firearms. ${ }^{286}$ Although it cannot be said for certain, one could perhaps tentatively assume that these rods may have had a similar function to ramrods.

After the projectile had been inserted into the barrel, it was usually additionally fastened with wedges (fig. 30). On the other hand, wedges were also used to aim cannons, by means of hammering them under the back part of the breech. ${ }^{287}$ Such wedges, as minor items, are only sporadically mentioned. In I 405 at Königsberg (Russ. Kaliningrad) i 3 Scot and I 2 Denars was paid for 500 shots (hagilschos) and 60 wedges for guns (kyle zu buchsen). ${ }^{288}$ Furthermore, 0.5 barrel of wedges for guns (o.5 tonne clotczer zcu bochsen) was recorded at Brandenburg (Russ. Ušakovo) in I $452 .{ }^{289}$

Gunpowder in firearms' breeches was ignited using various methods, such as matches, glowing iron rods or linstocks. ${ }^{290}$ Expenses on 3 entczundeysen were re-

\footnotetext{
${ }^{282} \mathrm{GÄDO}$ (as n. 26), pp. 88, 278, 282, 367, 4I 2, 653, 658, 656, 660, 663, 665, 668-669, 769-770; Schmidtchen (as n. 6), p. 36.

${ }^{283}$ NKRSME II (as n. 29), p. 95.

${ }^{284}$ GÄDO (as n. 26), p. 603.

285 GÄDO (as n. 26), p. 142.

${ }^{286}$ GÄDO (as n. 26), pp. 335, 339, 766-767; Visitationen I (as n. 26), No. I 23, p. 26 I; on ramrods in Teutonic sources see also Stępiński, Żabiński, Strzyż (as n. I 8), p. 179.

${ }_{287}$ Müller (as n. 77), p. I 9; Rathgen, Das Geschütz (as n. 4), p. I 3 I; see also Jakubowski (as n. 44), plate XIX, fig. 5 .

${ }^{288}$ MTB (as n. 23), p. 364; Engel, Nachrichten über Waffen (as n. 3), p. 232; Rathgen, Das Geschütz (as n. 4), p. 404; idem, Die Pulverwaffe (as n. 4), p. 25; Stępiński, Żabiński, Strzyż (as n. I 8), p. 175 .

289 GÄDO (as n. 26), p. 244; Stępiński, Żabiński, Strzyż (as n. ı 8), p. i 80.

${ }^{290}$ See e.g. Smith, DeVries (as n. 53), p. 258 ; Szymczak (as n. 19), p. 75; Oakeshott (as n. 53), p. 32; Schmidtchen (as n. 6), p. 7 I; Rathgen, Das Geschütz (as n. 4), p. 123.
} 
corded in the account book of Elbing (Pol. Elbląg) in I 404. ${ }^{291}$ These may have been simple iron rods, which were heated and then used to ignite the gunpowder charge. The entczuende haken (literally: igniting hook), mentioned in resources of the Town Hall in Elbing in I $4 \mathrm{I}^{292}$ was perhaps a more complex device. It may have been provided with a slow match. It cannot be excluded that similar devices were recorded there under the name of hoken czu buchsen. ${ }^{293}$ Czundehoken ( 3 and 4 respectively) were also mentioned among weaponry resources at Tilsit (Russ. Sovetsk) in I 419 and $1425 .{ }^{294}$ A fully developed form of linstock was recorded in 1516 at Neidenburg (Pol. Nidzica), where 8 such artefacts (fuerspiesse so gut sie seynt) were stored. ${ }^{295}$ An interesting piece of information is known from I 414 from Elbing (Pol. Elbląg) where 0.5 Ferto was paid for two pincers used to "put charcoal on guns" ( 2 czangen, do man dye kolen mete uff dy buchsen leyt). ${ }^{296}$ This suggests that guns were fired using a glowing piece of charcoal, which was held in special pincers and ignited the gunpowder charge. ${ }^{297}$

In case it was necessary to carry fire in the field, containers of various kind may have been used. In 1409 at Marienburg (Pol. Malbork) 4 pipes used by master gunners to carry fire were mentioned (roren, do der bochsenschocze fuwer mag inne tragen)..$^{298}$

When discussing methods of igniting the gunpowder charge, one must also pay attention to touch holes. After a long period of use, touch holes in cannons (with special reference to those made from copper and its alloys) could become burnt through and thus make the cannon less efficient. This is evidenced by a record from I 409, stating that a medium-sized gun was transported from Graudenz (Pol. Grudziądz) to Marienburg (Pol. Malbork), as its touch hole was widely burnt through (dy mittelbochse von Grudencz ken Marienburg zu furen, als das zondeloch

${ }^{291}$ NKRSME I (as n. 29), p. 16; Rathgen, Das Geschütz (as n. 4), pp. 427, 439; idem, Die Pulverwaffe (as n. 4), p. 67.

${ }^{292}$ EK (as n. 173), p. 253; Szymczak (as n. 19), p. 75; Chodyński, Inwentarz broni (as n. I I), pp. 74, 77-78; idem, The stores of arms (as n. I I), pp. 20, 22; Rathgen, Das Geschütz (as n. 4), p. 429; idem, Die Pulverwaffe (as n. 4), p. 72.

293 EK (as n. 173), p. 254; Rathgen, Das Geschütz (as n. 4), p. 429; idem, Die Pulverwaffe (as n. 4), p. 72; Chodyński, Inwentarz broni (as n. I I), pp. 75, 77-78; idem, The stores of arms (as n. I I), pp. 20, 22.

${ }^{294}$ GÄDO (as n. 26), pp. 278, 282; Stępiński, Żabiński, Strzyż (as n. I 8), p. I 80.

295 GÄDO (as n. 26), p. 348.

${ }_{296}$ NKRSME II (as n. 29), p. 95.

297 Oakeshott (as n. 53), p. 32.

${ }_{298}$ MTB (as n. 23), p. 572; Stępiński, Żabiński, Strzyż (as n. I 8), p. I75; Schmidtchen (as n. 6), p. 72; Rathgen, Das Geschütz (as n. 4), pp. 407, 420, 440; idem, Die Pulverwaffe (as n. 4), pp. 30 , 54, 89; Engel, Nachrichten über Waffen (as n. 3), p. 232. 
wyt gebrant was). ${ }^{299}$ Therefore, steel pipes were inserted into touch holes, as the former were more resistant to high temperatures and wear. Manufacture of such steel pipes by locksmiths is sometimes mentioned in Teutonic sources with regard to Marienburg (I I I - 5 Ferto dem kleynsmeden vor stelen yn czundelochen czu den buchsen und vor ander ding dy doczu gehoren und vor slos ${ }^{300}$; I 4 I I - I Mark dem cleynsmede vor stellyne czondelocher czu smeden czu bochsen ${ }^{301}$; I 4 I 2 - I Mark 2 Scot vor stelinne czundelocher czu den buchzen ${ }^{302}$; 14 I 4 - I 6 Scot vor stelin roren czu den nuwen bochssen czu den czondelager ${ }^{303}$ ). It is remarkable that an iron or steel pipe can be still seen in the touch hole of the light field cannon from Kauernick (Pol. Kurzętnik). ${ }^{304}$ Interestingly, a record from 14 I 4 concerning the Order's capital castle mentions a payment of 2 I 6 Denars for 9 locks, used to lock touch holes ( 9 slos zu den bochsen do mete man dy condelocher vorsluset). ${ }^{305}$ Traces suggesting the presence of a touch hole coverplate have been found on the powder chamber of the well-known Boxted bombard, which was a wrought iron heavy cannon. ${ }^{306}$ Another mention from I 4 I 4 concerns a payment of I 44 Denars for 6 slos czu den bochsen. ${ }^{307}$ As the price per item was the same (24 Denars), it can be supposed that the latter ention refers to identical devices. It I 4 I 5 at Marienburg (Pol. Malbork) 96 Denars was paid for 2 slosse czu den bochsen. ${ }^{008}$ As the price per item was twice as high as in the preceding year, it could be tentative explained that the locks from I 4 is were larger and perhaps meant for heavier cannons. There is also a record mentioning 2 priming pans for a gun in Engelsburg (Pol. Pokrzywno) (2 tegel czu der buchse). They belonged to a stone cannonball gun which was to be sent to Thorn (Pol. Toruń) for repair. ${ }^{309}$

\footnotetext{
299 MTB (as n. 23), p. 574; Stępiński, Żabiński, Strzyż (as n. I 8), p. I 8 I; Schmidtchen (as n. 6), p. 64; Rathgen, Das Geschütz (as n. 4), pp. 407, 440-44I; idem, Die Pulverwaffe (as n. 3 I), pp. 3 1, 90; Engel, Nachrichten über Waffen (as n. 3), p. 230 ; Toeppen (as n. I), p. I 57.

$300 \mathrm{ABMH}$ (as n. 25), p. 24.

${ }^{301}$ ABMH (as n. 25), p. 28.

$302 \mathrm{ABMH}$ (as n. 25), p. 62.

$303 \mathrm{ABMH}$ (as n. 25), p. I 43; Żabiński, Ways of acquisition (as n. 17), p. I 24; Rathgen, Das Geschütz (as n. 4), p. 42 I , 440-44I; idem, Die Pulverwaffe (as n. 4), p. 57; see also Goetz (as n. 76), p. 27. 304 Stępiński, Żabiński, Strzyż (as n. I 8), pp. $156-$ I 57 , Fig. 2.

305 ABMH (as n. 25), p. 148.

${ }^{306}$ R. D. Smith, R. R. Brown, Bombards Mons Meg and Her Sisters (Royal Armouries Monograph I), London 1989 , p. 57 , fig. 37 .

$307 \mathrm{ABMH}$ (as n. 25), p. I 48; for similar devices see also Rathgen, Das Geschütz (as n. 4), p. 365.

${ }_{308} \mathrm{ABMH}$ (as n. 25), p. I 87; on gun locks in the Order's artillery see also Rathgen, Das Geschütz (as n. 4), p. 44I; idem, Die Pulverwaffe (as n. 4), p. 90.

309 GÄDO (as n. 26), p. 589; Stępiński, Żabiński, Strzyż (as n. I 8), p. I 80; Rathgen, Das Geschütz (as n. 4), p. 397; idem, Die Pulverwaffe (as n. 4), p. 12.
} 
Tools which are sometimes mentioned in the context of firearms are hammers $^{310}$ (fig. 3 I ). Regrettably, available sources hardly inform us for what purpose these tools were used. A record from I 4 I 3 from Neumark which mentions I hammer and nails for the gun (I hamer und nagel czur buchsen $)^{311}$, implies that these tools may have been used for field repairs of gun stands.

Sporadically, there are also mentions concerning other tools associated with the use of firearms (fig. 32). The inventory of Memel (Lit. Klaipeda) from I 398 records one grease kettle (smerkessil) ${ }^{312}$, but without specifying its use. The list of the Order's firearms stores from c. I 523 mentions 900 shovels (schauffeln), 300 spades (spatten) and 100 picks (bicken)..13 The latter may have been used for the manufacture of stone cannonballs, although it must be remembered that at that time cast iron projectiles were already widespread. On the other hand, all these tools may have also been used for ground works related to the use of artillery in the field.

Such tools were sometimes stored in chests (fig. 33). The inventory of the Town Hall in Elbing (Pol. Elbląg) from I 413 mentions a chest (kysten) which contained 24 lead bullet guns (lotbuechsen), as well as linstocks and stoppers (entczuende haken unde proppen unde proppe yseren). ${ }^{314}$ This source also records two cloth chests (gewantkysten). The first one contained as many as 800 small stone cannonballs (kleine buchsensteine) and 44 stone cannonballs which were slightly larger. In the other chest there were 162 stone cannonballs which were even larger than the afore-mentioned ones. This chest also contained 4 boxes or small chests with various gun tools (4 laden adir kleine kysten, do der buchsen gerethe mancherleye inne is). The source also states that in the first chest there were 62 stone cannonballs for the largest guns. ${ }^{315}$ In the following year the municipal authorities of Elbing (Pol. Elbląg) spent 16 Scot on 2 long chests where gun equipment and stoppers could be stored (2 lange kasten do man das buchsengerethe unde proppen inlegen mag). ${ }^{316}$ Also in I 4 I 4 the same sum was spent on fitting 2 chests for

\footnotetext{
310 GÄDO (as n. 26), pp. 278, 282, 321, 367, 766-767, 770; MTB (as n. 23), p. 573; Stępiński, Żabiński, Strzyż (as n. I 8), pp. 175, 179; Schmidtchen (as n. 6), p. 33; Rathgen, Das Geschütz (as n. 4), p. 407.

${ }^{311} \mathrm{GÄDO}$ (as n. 26), p. 769.

312 GÄDO (as n. 26), p. 302.

313 Biskup (as n. 28), p. Iо I.

314 EK (as n. 173), p. 253; Chodyński, Inwentarz broni (as n. I I), pp. 74, 77-78; idem, The stores of arms (as n. I I), pp. 20, 22; Rathgen, Das Geschütz (as n. 4), p. 429.

315 EK (as n. 173), p. 254; Chodyński, Inwentarz broni (as n. I I), pp. 75, 77-78; idem, The stores of arms (as n. I I), pp. 20, 22; Rathgen, Das Geschütz (as n. 4), p. 429.

${ }^{316}$ EK (as n. 173), p. 260; NKRSME II (as n. 29), p. 80; Rathgen, Das Geschütz (as n. 4), p. 429; idem, Die Pulverwaffe (as n. 4), p. 7 I.
} 
gun equipment with iron ( 2 kasten zu beslan, do man das buchsengerete inlegt). ${ }^{317}$ It could be asked whether this record concerned the previously mentioned chests. The habit of storing gun equipment together with projectiles is also evidenced by other sources. ${ }^{318}$ Some records mention chests with projectiles only, such as those from Preußisch Mark (Pol. Przezmark). In I 507, I chest with small and large iron shots ( $I$ kasten mit eisern schrotten clein und gros) was recorded, while the inventory from I 508 mentions I kasten mit glotten clein und gros. ${ }^{319}$

Finally, for the sake of comparison it is worth mentioning a list of gun equipment stated in the manual of S. de Saint Remy from 1697 (fig. 34). ${ }^{220}$ The most important instruments are:

- charging ladles or "lanterns" (lanternes, cuillieres), composed of copper tubes and wooden shafts,

- ramrods (refouloirs), being wooden pounders on wooden shafts,

- bore brushes or sponges (ecouvillons), consisting of heads covered with ram's fleece or wild boar's bristle mounted on wooden shaft, sometimes provided with metal fittings (virolles) at the end of the shaft,

- wad-screws (tirebourres), or corkscrew-like tools used to unload the gun, mounted on wooden shafts,

- linstocks (bouttefeux), consisting of M-shaped heads to hold the match mounted on wooden shafts,

- chats (literally - cats), or hook-shaped instruments mounted on wooden shafts and used to examine cannon barrel bores for possible defects,

- priming irons (dégorgeoirs), or needle-or nail-shaped instruments for cleaning of touch holes. There are loops on their ends, preventing them from falling into the barrel,

- primers (fourniments), or leather flasks or horns which should contain at least one pound of ignition powder,

- leather sacks with ignition powder (sacs à amorce),

- funnels (entonnoirs), used to fill ignition powder into the touch hole,

- pointing wedges (coins de mire), used to regulate the angle of elevation of the barrel,

317 NKRSME II (as n. 29), p. 87; Rathgen, Das Geschütz (as n. 4), p. 429; idem, Die Pulverwaffe (as n. 4), p. 7 I.

${ }_{318}$ GÄDO (as n. 26), pp. 88, 91, 97, 105; Visitationen I (as n. 26), No. I 20, p. 250.

319 GÄDO (as n. 26), pp. I 47-1 48; Żabiński, Technology of manufacture (as n. 17), p. 93.

320 Saint Remy (as n. 43), pp. 7 I -76; a similar description is also offered by J. Jakubowski, see Jakubowski (as n. 44), pp. 265-270, plate VIII, figs. I 3-23; see also Boeheim (as n. 76), pp. 58-59, fig. I. 
- pointing frontons (fronteaux de mire), or rectangular pieces of hard wood with a semicircular hollowing in their bottom parts, placed under the barrel to regulate its angle of elevation,

- aprons (chapiteaux, or literally - capitals), consisting of two boards of hard wood joint obliquely; these were used to cover the touch holes of cannons against rain or dirt,

- levers (leviers), being long bars of had wood with wedge-shaped points.

\section{TOOLS FOR THE MANUFACTURE OF PROJECTILES}

Before the introduction of cast iron cannonballs at the end of the i 5 th century, stone was the most popular raw material for artillery projectiles. ${ }^{321}$ In the case of stone projectiles, the most frequently mentioned tools were picks. A series of expenses on the manufacture of I 50 stone cannonballs made by the House Commander of Königsberg (Russ. Kaliningrad) was recorded in 1403 and 7 Scot was spent on picks (bicken). Apart from that, I Ferto went for carburising of picks (bicken zu stelen), and another payment of 0.5 Mark for sharpening and carburising (vor scherfyn und stelyn) was recorded. Eventually, 4 Scot was spent on 2 spades, used to dig stones out of the ground (vor 2 spaten, do mete man die steyne us der erden hat gegraben). ${ }^{322}$ In 1407 at Königsberg 24 picks were stored together with guns and gunpowder. ${ }^{323}$ In the following year at Marienburg (Pol. Malbork) 3 Marks was spent on I 2 picks used to make large stone cannonballs (vor I 2 bicken, do ma dy grossen bochsensteyne mete hib). ${ }^{224}$ In 1409 the Order's Treasurer paid I 6 Scot and 20 Denars for sharpening of picks, as stone-cutters were manufac-

321 Strzyż, Broń palna (as n. 20), pp. 127-130, 247-250; idem, Średniowieczna broń palna (as n. 20), pp. 49-50, 59-69; Szymczak (as n. 19), pp. I 44- I 52; Arszyński, Sikorska-Ulfik (as n. 9), pp. 70-71; Goetz (as n. 76), p. 3 I; on stone projectiles from the Teutonic Order's state see also Strzyż, Czubla, Mackiewicz (as n. I3); P. Strzyż, Pociski do średniowiecznej broni palnej z pogranicza polsko-krzyżackiego, in: Arma et Medium Aevum. Studia nad uzbrojeniem średniowiecznym, ed. P. Kucypera, P. Pudło, G. Żabiński, Toruń 2009, pp. 198-223; idem, Zespót kamiennych kul (as n. I 3); A. Wasilewski, Późnośredniowieczne kule artyleryjskie znalezione na zamku w Pucku, Zapiski Puckie 3 (2004), pp. I 48-1 52; Świętosławski (as n. Io), p. 25.

${ }_{322}$ MTB (as n. 23), pp. 246-247.

$323 \mathrm{GÄDO}$ (as n. 26), p. I I.

324 MTB (as n. 23), p. 497; Stępiński, Żabiński, Strzyż 2013 (as n. I 8), p. 175; Żabiński, The Grose bochse (as n. 17), p. 37, tab. 4; Schmidtchen (as n. 6), p. 71; Rathgen, Das Geschütz (as n. 4), p. 405 ; idem, Die Pulverwaffe (as n. 4), p. 26. 
turing projectiles in Sobbowitz (Pol. Sobowidz). ${ }^{325}$ In the same year the House Commander in Thorn (Pol. Toruń) spent 8 Scot on one stone of steel, needed to sharpen picks. ${ }^{326}$ The purchase of metal actually implies a bit more extensive scope of repair than mere sharpening. It cannot be excluded that, e.g., working parts of these picks needed to be replaced. In the same year in Thorn another 5 Ferto went for sharpening of picks and for one large hammer for splitting stones (grosen schelhammer). ${ }^{327}$ There are also other mentions of expenses on repairs of picks. In I 4 I 0 in Elbing (Pol. Elbląg) 7.5 Marks was spent on carburising of picks used to make cannonballs (vor de picken to stelende, dar se mede de stene houwen). 5 Marks went on sharpening of picks, and 2 Scot was spent on an unspecified repair of another pick. Eventually, one new pick was bought for 0.5 Ferto. ${ }^{328}$ In I 4 I I the smithing master at the Order's capital castle received I Mark for sharpening of picks, to be given to a smith in Sobbowitz (Pol. Sobowidz) where stone cannonballs were made. ${ }^{329}$ Furthermore, there are other records mentioning stores of picks at the Order's castles. 2 picks were found in $14 \mathrm{I} O$ at Schönsee (Pol. Kowalewo (Pomorskie)) ${ }^{330}, 6$ large picks were kept in I 422 at Brandenburg (Russ. Ušakovo) ${ }^{331}$, and 3 picks were recorded in 1432 at Nessau (Old Pol. Nieszawa), now part of Thorn (Pol. Toruń). ${ }^{32}$ As mentioned above, roo picks were stored about I 523 at Königsberg (Russ. Kaliningrad). ${ }^{333}$

Another tool used in the manufacture of projectiles were pincers. Large iron pincers for stone projectiles (grosse yserene czange czu steinen) were recorded in I 4 I 3 in the inventory of the Town Hall in Elbing (Pol. Elbląg). ${ }^{34}$ On the other hand, A. R. Chodyński interprets these pincers as tools used to ignite stone can-

\footnotetext{
325 MTB (as n. 23), p. 523; Żabiński, Ways of acquisition (as n. 17), p. I 35; Stępiński, Żabiński, Strzyż (as n. I 8), p. I75.

${ }_{326}$ MTB (as n. 23), p. 596.

327 MTB (as n. 23), p. 597; Schmidtchen (as n. 6), p. 7 I; Rathgen, Das Geschütz (as n. 4), p. 409; idem, Die Pulverwaffe (as n. 4), p. 33.

${ }_{328}$ NKRSME I (as n. 29), p. 230; Rathgen, Das Geschütz (as n. 4), p. 428; idem, Die Pulverwaffe (as n. 4), p. 69.

$329 \mathrm{MKB}$ (as n. 24), p. 252.

330 GÄDO (as n. 26), p. 4 I 2; Żabiński, Ways of acquisition (as n. 17), p. I 27; Schmidtchen (as n. 6), p. 36.

331 GÄDO (as n. 26), p. 222; Żabiński, Ways of acquisition (as n. 17), p. I 27.

$332 \mathrm{GÄDO}$ (as n. 26), p. 484-485.

333 Biskup (as n. 28), p. го I.

334 EK (as n. 173), p. 254; Szymczak (as n. 19), p. 75; Chodyński, Inwentarz broni (as n. I I), pp. 77-78; idem, The stores of arms (as n. I I), p. 22; Rathgen, Das Geschütz (as n. I I), p. 430; idem, Die Pulverwaffe (as n. I I), p. 72.
} 
nonball cannons ${ }^{335}$, which seems to be a misunderstanding, as the source clearly speaks of stone projectiles.

In order to ensure proper dimensions of stone projectiles, compasses and callipers of various kind were used. In 1408 at Marienburg (Pol. Malbork) a carpenter was paid $4 \mathrm{Scot}$ for making $\mathrm{C}$-shaped devices used for the manufacture of cannonballs (dem tischer vor kromme holzer zu machen noch zirkelmose, do man dy grosen bochsensteyne hoch gehawen hat). ${ }^{336}$ In I 4 I 4 in Elbing (Pol. Elbląg) 0.5 Ferto was spent on a ring, through which stone projectiles were beaten (vor I ring, do man dy steine czu den buchsen durchbib). ${ }^{337}$ Interestingly, such rings with handles (socalled passe-boulets or passe-balles), which were used to make sure that projectiles were of proper calibre, are mentioned in the work of S. de Saint Remy (fig. 35).338

Much less is said on tools used in the manufacture of metal projectiles. ${ }^{339}$ In I $4 \mathrm{I} O$ in Elbing (Pol. Elbląg) 4 Marks was spent on a pan for a bullet founder (vor ene panne, de kofft de lotgeter). ${ }^{40}$ Furthermore, one founding cauldron (giszkessel) was recorded in the inventory of the Order's castle in Brandenburg (Russ. Ušakovo) in $1452 . .^{341}$ Eventually, a set of instruments including a copper mould for bullets (coppern forme zu geloten), a stone mould (gissteyn) and a casting ladle (gisskelle) (fig. 36) was recorded as part of weaponry resources sent from Thorn (Pol. Toruń) to the Prussian Confederacy troops which were besieging Schwetz (Pol. Świecie) in I $46 \mathrm{r} .^{342}$

335 Chodyński, Inwentarz broni (as n. I I), p. 75; idem, The stores of arms (as n. I I), p. 20; see also Szymczak (as n. 19), p. 337.

${ }_{336}$ MTB (as n. 23), p. 497; Stępiński, Żabiński, Strzyż (as n. 1 8), p. I75; Żabiński, The Grose bochse (as n. 17), p. 37, tab. 4; Schmidtchen (as n. 6), p. 65; Rathgen, Das Geschütz (as n. 4), pp. 405, 433; idem, Die Pulverwaffe (as n. 4), p. 26; Engel, Nachrichten über Waffen (as n. 3), p. 23 I; on similar devices see Szymczak (as n. 19), pp. 145-1 46, fig. 26c; and Górski (as n. 53), p. 43.

337 NKRSME II (as n. 29), p. 94; Żabiński, Ways of acquisition (as n. I7), p. 135.

338 Saint Remy (as n. 43), pp. 82-83.

339 On metal projectiles see e.g. Strzyż, Broń palna (as n. 20), pp. I I3-i I 8, 244-246; idem, Średniowieczna broń palna (as n. 20), pp. 50-53, 70-73; Smith, DeVries (as n. 53), p. 253; Szymczak (as n. 19), p. I 52-1 57; Świętosławski (as n. I0), p. 25.

340 NKRSME I (as n. 29), p. 229; Żabiński, Technology of manufacture (as n. 17), p. 103; Rathgen, Das Geschütz (as n. 4), p. 427; idem, Die Pulverwaffe (as n. 4), p. 68.

${ }^{341}$ GÄDO (as n. 26), p. 244; Żabiński, Technology of manufacture (as n. 17), p. 103; idem, Ways of acquisition (as n. I7), p. I 27; Stępiński, Żabiński, Strzyż (as n. I 8), p. ı 80.

${ }_{342}$ Biskup (as n. 31), p. 89; Żabiński, Technology of manufacture (as n. 17), p. 104. 


\section{EQUIPMENT RELATED TO GUNPOWDER}

Concerning gunpowder, tools used for its manufacture will be discussed first (fig. 37).343 The work of Johannes Bengedans mentions copper kettles for cleaning (luteren) of saltpetre ${ }^{344}$, as well as pots with lids for preparing gunpowder. ${ }^{345}$ The inventory of Ortelsburg (Pol. Szczytno) from I 52 I recorded 4 kienphan in the gunpowder chamber (pulfferchammer). ${ }^{346}$ It cannot be excluded that these were vessels related to a certain stage of gunpowder manufacture.

An indispensable tool were pounders of various kinds. ${ }^{347}$ In 1409 the House Commander of Thorn (Pol. Toruń) spent I Mark 2 Scot on an iron club or pestle used to pound gunpowder (yserynne kolwe, polfer domete yn zu stossen)..$^{348}$ The inventory of Königsberg (Russ. Kaliningrad) from I 446 mentions 35 poffoysen among resources of gunpowder and saltpetre. ${ }^{349}$ These artefacts may have been iron feet of pounders. One tool of this kind was also recorded two years thereafter at Insterburg (Russ. Černyahovsk). ${ }^{350}$ Although not many details are known from sources from the territory of the Order's state, it can be supposed that some gunpowder pounders were more complex devices. This is suggested by a record from I 4 I 4 from Elbing (Pol. Elbląg), mentioning a payment of 2 Scot for nails used to prepare strings in order to pound gunpowder (vor negele, vor strenge mete anczurichten, das pulver czu stosen). ${ }^{351}$

Another necessary tool in the manufacture of gunpowder were sieves. ${ }^{352}$ In I 40 I at Marienburg (Pol. Malbork) 2.5 Marks was spent on one gunpowder sieve (pulversyp) and 4 charcoal pans (kolphannen). ${ }^{353}$ The latter were perhaps used as containers for glowing charcoal. Four year thereafter, 72 Denars went for one

343 For general data on gunpowder manufacture see e.g. McLachlan (as n. 53), pp. 7, i o- I 2, i 8-26; Szymczak 2004 (as n. I9), pp. I 22-I 38; Oakeshott (as n. 53), pp. 34-35; Rathgen, Das Geschütz (as n. 4), pp. 93-I I I; Górski (as n. 53), p. 29.

344 Bengedans (as n. 40), chapter 5, p. I 6.

345 Bengedans (as n. 40), chapter I 2, p. 26.

346 GÄDO (as n. 26), p. 123.

347 See e.g. Rathgen, Das Geschütz (as n. 4), p. I о I.

${ }_{348}$ MTB (as n. 23), p. 597; Żabiński, Ways of acquisition (as n. I 7), p. I 28; Engel, Nachrichten über Waffen (as n. 3), p. 232; Toeppen (as n. I), p. 23 I.

349 GÄDO (as n. 26), p. 45; Visitationen I (as n. 26), No. I 22, pp. 259-260.

350 GÄDO (as n. 26), p. 65.

351 NKRSME II (as n. 29), p. 79; Rathgen, Das Geschütz (as n. 4), p. 428.

352 See e.g. Smith, DeVries (as n. 53), p. 247.

353 MTB (as n. 23), p. I 27; Żabiński, Ways of acquisition (as n. I 7), p. I 28; Engel, Nachrichten über Waffen (as n. 3), p. 232. 
gunpowder sieve and 4 measures for gunpowder (polvermoes). ${ }^{354}$ In I 409, among expenses on gunpowder making at the Order's capital castle there were io Scot on 5 sieves and 0.5 Mark on 4 sieves. 355 The price of about 2 Scot per sieve is also confirmed by other sources. This was the case in Elbing (Pol. Elbląg) in 1410356 and Marienburg (Pol. Malbork) in I 4I I. ${ }^{357}$ There is also data on more expensive artefacts, such as those mentioned in I 4 I 4 at the Order' capital castle. In this case, the price of 3 polffersewe was I 2 Scot and 24 Denars. 358

Gunpowder was manufactured in special premises, i.e., powder mills. Regrettably, available sources from the Order's state do not yield much data on this issue. In I 409 at Marienburg (Pol. Malbork) a series of expenses was made on gunpowder manufacture. 3 Marks was paid to an oil-maker for using the mill, powered by his own horses (dem olesleger vor dy mole, yo von der tonne 8 Scot, mit synen pferden zu tryben). ${ }^{359}$ Another 3 Marks was paid, perhaps to the same specialist, for making I 4 barrels of gunpowder (dem olesleger vor dy mole, I 4 tonnen polfer). ${ }^{360}$ Furthermore, 7 Ferto was paid to the oil-maker for a mill in Neuteich (Pol. Nowy Staw) near the Order's capital for 6 barrels of gunpowder (dem olsleger vor dy mole zum Nuwentyche, 6 tonne polfer gemachet). ${ }^{361}$ These expenses were made in Autumn, already after the outbreak of the war with Kingdom of Poland and Grand Duchy of Lithuania. This strongly suggests that the Order was forced to make use of all available resources to meet the demand for explosives.

As mentioned above, gunpowder measures were mentioned in $\mathrm{I} 4 \mathrm{O} \mathrm{I}$ at Marienburg (Pol. Malbork). Another record of such tools is also known from the Order's capital castle from I 409, when 4 measures made from metal sheet were mentioned (polfermesechen von bleche gemacht). These were bought for 4 Scot, together with 4 pipes for carrying fire. ${ }^{362}$

\footnotetext{
354 MTB (as n. 23), p. 364; Stępiński, Żabiński, Strzyż (as n. I 8), p. I75; Rathgen, Das Geschütz (as n. 4), p. 404; idem, Die Pulverwaffe (as n. 4), p. 25).

355 MTB (as n. 23), p. 587.

${ }^{356}$ NKRSME I (as n. 29), p. 229; Chodyński, Inwentarz broni (as n. I I), p. 72; idem, The stores of arms (as n. I I), p. 17; Świętosławski (as n. I0), p. 27; Rathgen, Das Geschütz (as n. 4), p. 428; idem, Die Pulverwaffe (as n. 4), p. 69.

357 ABMH (as n. 25), pp. 10, 28.

$358 \mathrm{ABMH}($ as n. 25), p. I 47.

359 MTB (as n. 23), p. 587.

${ }_{360} \mathrm{MTB}($ as n. 23), p. 587.

${ }_{361}$ MTB (as n. 23), p. 587; on these records see also Żabiński, Ways of acquisition (as n. 17), p. I 28; Rathgen, Das Geschütz (as n. 4), pp. 437-438; idem, Die Pulverwaffe (as n. 4), pp. 84-86 ; Toeppen (as n. I), p. I 54.

${ }_{362}$ MTB (as n. 23), p. 572; Schmidtchen (as n. 6), p. 72; Engel, Nachrichten über Waffen (as n. 3), p. 232; Toeppen (as n. I), p. 233.
} 
The next issue are containers for storing gunpowder, components used in its manufacture, as well as ammunition. With regard to gunpowder and its components, the most popular ones were barrels - they are mentioned so many times in sources that it is impossible to deal with them individually. The most common term for a barrel was tonne (tunne, thunne). Other terms which were in use were vas (fas) and its diminutive veschin (vessgen, feschen, veszlein), as well as loge (lagel). ${ }^{663}$ It must of course be remembered that these terms could refer both to physical containers and to volume units. Tonne was a volume unit which was I/ I 2 of Last (I Last was c. 3 I 43.22 litres). I Tonne would therefore equal to c. 26 I.94 litres. Loge was a volume unit used for wine and it equaled to c. 72.76 litres. ${ }^{364} \mathrm{As} \mathrm{far}$ as Vas is concerned, J. A. Eytelwein mentions a Modern Period unit used in Hamburg. ${ }^{365}$ Its volume equals to c. 58.43 litres. Furthermore, this author also mentions a Modern Period Prussian system of beer volume units, in which i Faß equalled to 2 Tonnen. ${ }^{366}$ After a conversion to the metrical system, I Tonne would equal to c. I 4 .5 litres. It may be asked, however, to what extend this data was relevant for the discussed period. An interesting piece of information was recorded in 1408 at the Order's capital castle. 5 i i. 5 Marks and 5 Scot was spent of 280 stones of saltpetre and the delivery was shipped in 23 logen und in eyme vasse. ${ }^{367}$ The saltpetre was bought in Breslau (Pol. Wrocław) in Silesia, so one can assume that its weight was expressed in local measures. I stone in Breslau was about $\mathrm{o}$ kg, while in Prussia it could equal to between c. 10 and c. $14 \mathrm{~kg}$, depending on the town. ${ }^{68}$ Using the Silesian unit, one receives c. $2800 \mathrm{~kg}$. The density of $\mathrm{KNO}_{3}$ is $2.109 \mathrm{~g} / \mathrm{cm}^{3}$, so the volume of the purchased saltpetre was about 1327.64 litres. Taking the Loge of c. 72.76 litres, the purchased amount of saltpetre matches about i 8.25 such units. Therefore, the Logen mentioned in 1408 must have been much smaller, perhaps

363 Ältere Hochmeisterchronik (as n. 32), pp. 647-648; Biskup (as n. 28), p. 102; EK (as n. 173), pp. 253-254, 260; GÄDO (as n. 26), passim; KŻZP (as n. 31), pp. 102, I04; MÄB (as n. 26), pp. 19-20, 22-24, 30-39; MTB (as n. 23), pp. 287, 428, 494, 5 14, 587 ; NKRSME I (as n. 29), p. 229; NKRSME II (as n. 29), pp. 32, 79; Visitationen I (as n. 26), No. 89, p. 103; No. 90, p. III; No. 91, p. I I ; No. 92, p. I I9; No. 107, p. I83; No. 108, p. I84; No. I I0, p. I85; No. III, p. I87; No. II 6, p. 2 I I; No. I I7, p. 2 I 4; No. II 8, p. 22 I; No. I22, pp. 259-260; No. I 20, pp. 249-250; No. I 23, pp. 261-262; No. I 24, p. 276; No. I 25, pp. $278-279$; No. I 33 , p. 305 ; No. I 34, p. 322 ; Visitationen 2 (as n. 26), No. I 47, pp. 2 I, 24-29, 31, 32, 35, 37-38, 40, I07; No. 176, pp. I $52-153$.

${ }_{364}$ See also Kwiatkowski (as n. 16), p. 255 , Scheme 4.

365 J. A. Eytelwein, Vergleichungen der gegenwärtig und vormals in den königlich preußischen Staaten eingeführten Maaße und Gewichte mit Rücksicht auf die vorzüglichsten Maaße und Gewichte in Europa, Berlin i 8 1 о, pp. 89, 9 1.

${ }_{366}$ Eytelwein (as n. 365), p. 96.

367 MTB (as n. 23), p. 5 I 4.

${ }^{368}$ See e.g. Kwiatkowski (as n. 16), p. 255, Scheme 4; Schmidtchen (as n. 6), p. 27. 
c. 50 litres each. The Vass from 1408 may have been around 170 litres, i.e., about half of the volume of the Tonne. In I 4 I 4 in Elbing I Mark I 8 Denars was spent on 13 vessgen zu pulver, while a Tonne for gunpowder with a volume of 0.5 Last was purchased for 9 Scot. ${ }^{369}$ The price of $I$ vessgen would equal to less than 2 Scot, which suggests that the volume of the Lasttonne was about 4.5 times larger than that of the vessgen. Taking the afore-mentioned volume of c. 3 I 43.22 litres for I Last, the volume of the vessgen would equal to c. 349.25 litres.

When discussing stores of gunpowder and its components, in some cases it is possible to assume that terms used in sources actually referred to containers. For instance, in I $4 \mathrm{I} 3$ the inventory of the Town Hall in Elbing (Pol. Elbląg) recorded 3 quarters of a barrel of sulphur, stored in two half-empty barrels ( 3 virdel van I tonne swefel, der is in 2 halben tonnen). This inventory also mentions a barrel of sulphur which weights i 0.5 stones minus 3 or 4 pounds (I tonne swevels, dy wyget I 0.5 stein minus 3 adir 4 pfunt). I 0.5 stones would equal to about $144.58 \mathrm{~kg} .{ }^{370}$ As the density of solid sulphur is about $2 \mathrm{~g} / \mathrm{cm}^{3}$, the volume of $144.58 \mathrm{~kg}$ would equal to about 72.29 litres. Quite obviously, one should take differences in density between solid and pulverised sulphur into consideration (the density of the latter could be even two times smaller, so its volume would be two times greater). Anyway, this would mean that the barrel in question was either filled up to c. $30-60 \%$ of its capacity or that another barrel was used, whose capacity was much smaller than the mentioned "standard" c. 26r.94 litres. The latter assumption receives support from the record of a purchase of one barrel of sulphur in Elbing (Pol. Elbląg) in I 4 I 4 . The barrel weighed I 4 stones and Io pounds and was bought for I 0 Marks and I 8 Scot (I tonne swevel, dy wuk I4 steine und Io lb, den stein vor I 8 sc)..$^{371}$ The weight of the sulphur would be about $196.83 \mathrm{~kg}$, while its volume in the solid state would equal to c. 98.4I litres and two times that much in the pulverised state.

For other mentions of barrels as containers, in I4Is at Schlochau (Pol. Człuchów) there were 2.25 barrels with lime wood charcoal (vas mit lyndynnen kolen). ${ }^{372}$ Interestingly, the inventory of that castle from 1420 mentioned I quarter with lime wood charcoal (I fyrtil mit lyndynnen kolen). ${ }^{373}$ In this case the quarter could be understood either as a quarter of the vas from i 4 I 5 (whose capacity was

\footnotetext{
${ }^{369}$ EK (as n. 173), p. 260; NKRSME II (as n. 29), p. 79; Rathgen, Das Geschütz (as n. 4), p. 429; idem, Die Pulverwaffe (as n. 4), p. 7 I.

370 Kwiatkowski (as n. 16), p. 255.

${ }^{371}$ NKRSME II (as n. 29), p. 79; Rathgen, Das Geschütz (as n. 4), p. 428; idem, Die Pulverwaffe (as n. 4), p. 70 .

372 GÄDO (as n. 26), p. 653.

373 GÄDO (as n. 26), p. 656.
} 
unspecifed), or as a volume unit, being $1 / 4$ of the Tonne (i.e., c. 65.48 litres). ${ }^{374}$ I barrel of saltpetre was stored in 14 I 8 at Danzig (Pol. Gdańsk) and it was recorded that it was not full ( $I$ tonne salpeter und ist nicht vol). ${ }^{375}$ In I 425 at Tilsit (Russ. Sovetsk) there were $\mathrm{I}$ and $3 / 4$ barrels of gunpowder and one of these was not full, lacking about I quarter (tonnen pulver, eine ist bey eynem firtel nicht vol). ${ }^{376}$ In 1430 at Schönsee (Pol. Kowalewo (Pomorskie)) there were 2 barrels of gunpowder, which were, however, not full (2 tonnen pulver aber nicht foil). ${ }^{377}$ Furthermore, in 1433 at Schlochau (Pol. Człuchów) there was i feschen mit swebele..$^{38}$ The same expression was used in I 446 at Elbing (Pol. Elblag), where I2.5 tonnen mit pulver were recorded ${ }^{379}$, as well as in 1449 at Rehden (Pol. Radzyń (Chełmiński)) (2 veschen mit pulver, I veschen mit salpeter, I veschen mit swebel). ${ }^{380}$ This was also the case at Neidenburg (Pol. Nidzica) in I 485 and I 488 , where $I$ thonne mit pulver und 6 pfund was recorded ${ }^{81}$, at Preußisch Mark (Pol. Przezmark) in 1507 and I 508 (6 fessichen mit pulver) ${ }^{382}$, as well as at Osterode (Pol. Ostróda) in 1507 and I 508 (4 fessichen mit pulfer). ${ }^{383}$ Furthermore, the inventory of Ortelsburg (Pol. Szczytno) from I 507 mentioned 3 quite full barrels of gunpowder (3 fessichen pulfer gar fol). ${ }^{384}$ Interestingly, a year thereafter 3 vessichen mit pulffer nicht gantz vol were recorded there. ${ }^{385}$ A similar expression can be found in I 5 i 8 at Mohrungen (Pol. Morąg), where $I$ thon salbetir nicht fol was mentioned. ${ }^{386}$ Eventually, 2 faessgen mit pulver were recorded at Rhein (Pol. Ryn) in I $524 .{ }^{387}$

Barrels understood as containers (fig. 22) are also mentioned in non-inventory sources. In 1408 at Marienburg (Pol. Malbork), in the course of preparations for an expedition to Livonia, 4 empty barrels (ledige tonnen) were commisioned. These were to be used for gunpowder, oats, groats and bread (zum polfer, erwis, grocze und zum brote). ${ }^{38} \mathrm{~A}$ year thereafter, as part of expenses on gunpowder mak-

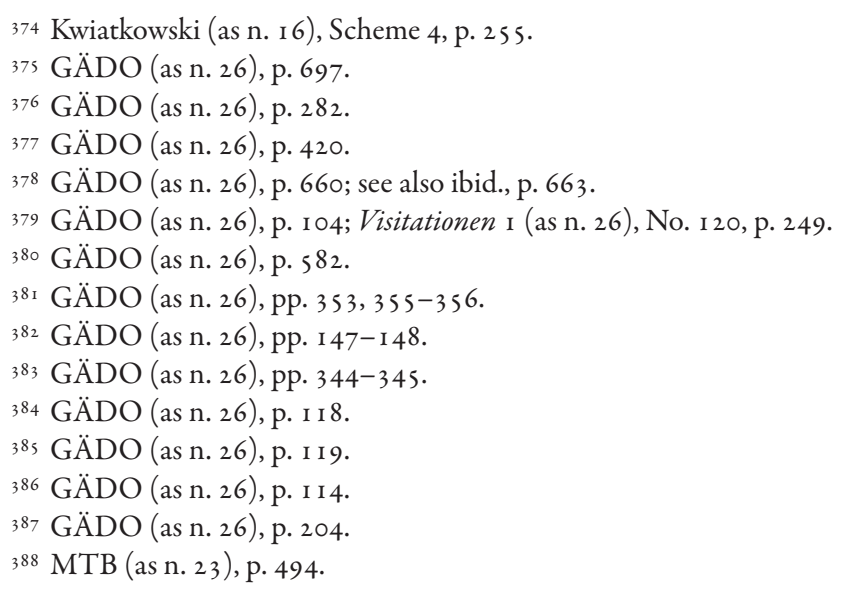


ing at the Order's capital castle, 7 Scot was spent on 0.5 Last of barrels. Another 4 Scot was paid to a cooper for binding barrels and fitting them with iron (eyme botcher vor dy tonnen $z u$ binden und zu slohen). ${ }^{389}$ Further expenses on gunpowder making in 1409 at Marienburg (Pol. Malbork) included ıo Scot for barrels (tonnen zum polfer) and 4 Scot for fitting a barrel with iron (dy tonne zuzuslohen). Furthermore, 96 Denars went for 8 barrels for gunpowder to a guardian of the lowest gate (vor 8 tonnen zu polfer vom nedersten thorwerter). 390

Barrels were sometimes used for storing projectiles. This was the case in I $4 \mathrm{I} 3$ in Elbing (Pol. Elbląg), where there was a half-barrel with lead bullets ( $I / 2$ tonne mit loeten). ${ }^{391}$ Furthermore, in 15 I 8 at Preußisch Holland (Pol. Pasłęk) shots were kept in a small barrel (etlisch schock schrot in eim feschen). ${ }^{392}$

Apart from barrels, gunpowder and its components were also stored in sacks (Fig. 38). As it was the case with barrels, most inventory records of such sacks are very schematic and they merely state their number in a given premise. ${ }^{393}$ Some mentions, however, contain more detailed pieces of information. For instance, the inventory of Schwetz (Pol. Świecie) from 1392 recorded i 3 leather sacks with gunpowder (lederynne secke mit pulver). ${ }^{394}$ The choice of leather for gunpowder sacks seems to well-founded, as it certainly offered much better protection against moisture than cloth. The use of leather is also confirmed by other sources. The inventory of Schlochau (Pol. Człuchów) from I4I3 mentions 8 lederyn secke mit pulver ${ }^{395}$, and one such sack was also mentioned at Lötzen (Pol. Giżycko) in I $420^{396}$ and at Schaaken (Russ. Nyekrasovo) near Königsberg (Russ. Kaliningrad) in $1422 .{ }^{397}$

An interesting record comes from Elbing (Pol. Elbląg), where in I 4 i o a certain Bertold Schumaker was paid 16 Scot for 22 secke to pulver. ${ }^{398}$ If his family

\footnotetext{
${ }_{389} \operatorname{MTB}($ as n. 23), p. 587.

390 MTB (as n. 23), p. 587.

${ }^{391}$ EK (as n. 173), p. 253; Chodyński, Inwentarz broni (as n. I I), pp. 74, 77-78; idem, The stores of arms (as n. I I), pp. 20, 22; Rathgen, Das Geschütz (as n. 4), p. 429.

392 GÄDO (as n. 26), p. I I I.

393 EK (as n. 173), p. 253, see also Chodyński, Inwentarz broni (as n. I I), pp. 74, 77-78; idem, The stores of arms (as n. I I), pp. 20, 22; GÄDO (as n. 26), pp. 68, 87, 21 7, 267, 278, 282, 430, 443, $467,470,615,653,656,658,688,747,766-767$; Visitationen I (as n. 26), No. 107, p. I 83.

394 GÄDO (as n. 26), p. 6 I 4; Schmidtchen (as n. 6), p. 39.

395 GÄDO (as n. 26), p. 652; Toeppen (as n. I), p. 23 I.

396 GÄDO (as n. 26), p. 197.

397 GÄDO (as n. 26), p. 23.

${ }_{398}$ NKRSME I (as n. 29), p. 229; Chodyński, Inwentarz broni (as n. I I), p. 72; idem, The stores of arms (as n. I I), p. I7; Świętosławski (as n. I0), p. 27; Rathgen, Das Geschütz (as n. 4), p. 428; idem, Die Pulverwaffe (as n. 4), p. 69.
} 
name was related to his profession, it can also be naturally assumed that leather was used as raw material. Furthermore, a price of a sack can be calculated at less than 22 Denars. On the other hand, prices of gunpowder sacks varied considerably, which was no question related to differences between sacks as such, in all probability concerning their sizes and types of leather that was used. For instance, in 1409 at Marienburg (Pol. Malbork) 9 Scot was paid for making 7 gunpowder sacks (polfersecke zu machen) ${ }^{399}$, which implies a price of more than 38.5 Denars per item. A year thereafter in Elbing, 7 gunpowder sacks were purchased for 0.5 Mark ${ }^{400}$, which means that one such sack cost almost 5 I. 5 Denars. Gunpowder sacks bought in I 4 I 4 at Marienburg were slightly more expensive -8 sacks went for 14 Scot and 12 Denars ${ }^{401}$, which gives a price of 54 Denars per item.

Small sacks were also used to store projectiles, as evidenced by the inventory of Osterode (Ostróda) from I 5 I 6, which mentioned $I$ seckleyn mit glote. ${ }^{402}$

As far as other containers are concerned, there are individual mentions of troughs, in which projectiles and gunpowder components were kept. One large through with iron shots (grosse mulde mit eisern schrotten) was recorded in 1507 and 1508 at Preußisch Mark (Pol. Przezmark). ${ }^{403}$ From the same years comes a mention of one through with sulphur (mule mit schwefel/mulde mit schwebel), stored at Osterode (Pol. Ostróda). ${ }^{404}$ Furthermore, there are several records of powder flasks, which were in some cases mentioned together with hand-held firearms. Interestingly, all this data comes from the last period of the Order's existence in Prussia. In 1507 at Rastenburg (Pol. Kętrzyn) there were 6 hackbuts with 4 powder flasks ( 6 hockenbuchssen dartzu sint 4 flaschen) and 4 handbuchsen with 4 powder flasks and moulds, perhaps for casting of projectiles (4 handtbuchssen und 4 flaschen mit formen). ${ }^{405}$ Interestingly, the inventory of Rastenburg (Pol. Kętrzyn) from 1508 mentions only 4 handbuchssen and 4 flaschen mit formen. ${ }^{406}$ 4 buchssenflaschen were stored at Lötzen (Pol. Giżycko) in I 507 and I $508 .{ }^{407}$ On the other hand, the inventory of the castle in Lötzen (Pol. Giżycko) from I 5 I 3

\footnotetext{
399 MTB (as n. 23), p. 573; Rathgen, Das Geschütz (as n. 4), p. 407; idem, Die Pulverwaffe (as n. 4), p. 30.

${ }^{400}$ NKRSME I (as n. 29), p. 246; Rathgen, Das Geschütz (as n. 4), p. 428; idem, Die Pulverwaffe (as n. 4), p. 70.

${ }^{401} \mathrm{ABMH}$ (as n. 25), p. 149.

402 GÄDO (as n. 26), p. 348.

${ }^{403}$ GÄDO (as n. 26), pp. I 47-1 48; Żabiński, Technology of manufacture (as n. I7), p. 93.

404 GÄDO (as n. 26), pp. 344-345.

405 GÄDO (as n. 26), p. I 84.

${ }^{406}$ GÄDO (as n. 26), p. 185.

$407 \mathrm{GÄDO}$ (as n. 26), pp. 25 I-252.
} 
mentioned 4 pulverflaeschen ${ }^{408}$, but it can be assumed that both terms referred to the same artefacts.

\section{CONCLUSIONS AND SUGGESTIONS FOR FURTHER RESEARCH}

The available data allow for a reasonable discussion on firearms' equipment in the Teutonic Order's state in Prussia. We are informed about a broad repertoire of equipment associated with guns, from gun stocks, beds, carriages and wagons, via gun equipment (charging ladles, ramrods, linstocks, aiming wedges, chests, barrels, sacks and so on) to tools used in the manufacture of projectiles (picks, hammers, compasses, passe-balle rings, casting ladles and moulds) and gunpowder (sieves, pounders). In many cases, it is possible to identify kinds of gun beds, trestles or carriages. Concerning the latter, it is noteworthy that the appearance of wheeled carriages as early as the beginning of the $\mathrm{I} 5$ th century can be proven for the Order's state. In numerous instances an analysis of prices of individual elements of gun equipment can be carried out.

On the other hand, this discussion has its limitations, which are chiefly due to the very nature of sources. As already stated in the Introduction, the discussed period is very unevenly covered with written source data. Written accounts, which are the main bulk of source data, rarely mention construction details of equipment, such as, e.g., wood species used in the manufacture of gun stocks or stands. It is in a handful of cases only that it is possible to relate the discussed equipment to a particular gun. The famous Teutonic Grose Bochse is a notable example, as in this case there is a lot of data on its bed, wagon and its parts, as well as other equipment.

Most regrettably, there are hardly any sources available than written accounts. There are only few surviving finds of firearms from the Order's state in Prussia and in their case only barrels survived (as mentioned above, there are strong doubts concerning the stock of the Curonian Spit handbuchse). The lion's share of archaeological finds are projectiles, chiefly stone cannonballs. Iconographic evidence is also sparse and it does not allow for a thorough reconstruction of all details.

All in all, with the help of available sources and comparative data it is possible to offer a reasonably informative image of gun equipment in the Order's state. It can be hoped that new research will bring more evidence to light. It seems that there is still some potential in unpublished archival records, with special reference to municipal sources and diplomatic correspondence, especially from periods of armed conflicts in which the Order participated. New discoveries can also be

${ }^{408}$ GÄDO (as n. 26), pp. $252-254$. 
made by archaeology, although it must be remembered that artefacts made from organic material (such as, e.g., wooden stocks) are usually much more prone to decomposition than metal barrels.

\section{Edited Sources And Literature}

Biskup, Marian., Janosz-Biskupowa, Irena., eds., with Udo Arnold. Visitationen im Deutschen Orden im Mittelalter. Part I (I236-I449). (Quellen und Studien zur Geschichte des Deutschen Ordens 50, I). Marburg: Elwert, 2002.

Biskup, Marian., Janosz-Biskupowa, Irena., eds., with Udo Arnold. Visitationen im Deutschen Orden im Mittelalter. Part 2 (I450-ISIg). (Quellen und Studien zur Geschichte des Deutschen Ordens 50,2). Marburg: Elwert, 2004.

Blosen, Hans., Olsen, Rikke A., eds. Krigskunst og kanoner / Kriegskunst und Kanonen. Das Büchsenmeister-und Kriegsbuch des Johannes Bengedans. Aarhůs: Aarhůs Universitetsforlag, 2006.

Czacharowski, Antoni., ed. Ksiegga żotdu Zwiazku Pruskiego z okresu wojny trzynastoletniej 1454-I466. (Towarzystwo Naukowe w Toruniu. Fontes 6I). Toruń: Towarzystwo Naukowe w Toruniu, 1969.

Grunau, Simon., Preussische Chronik. Vol. I, edited by Max Perlbach. In Die Preussischen Geschichtschreiber des XVI. und XVII. Jahrhunderts. vol. I. Leipzig: Verein für die Geschichte der Provinz Preussen, I 876.

Grunau, Simon., Preussische Chronik. Vol. 2, edited by Max Perlbach. In Die Preussischen Geschichtschreiber des XVI. und XVII. Jahrbunderts. vol. 2. Leipzig: Verein für die Geschichte der Provinz Preussen, I 889.

Grunau, Simon,, Preussische Chronik. Vol. 3, edited by Paul Wagner. In Die Preussischen Geschichtschreiber des XVI. und XVII. Jahrbunderts. vol. 3. Leipzig: Verein für die Geschichte der Provinz Preussen, I 889.

Hirsch, Theodor., Töppen, Max., Strehlke, Ernst., eds. Scriptores Rerum Prussicarum. Die Geschichtsquellen der preussischer Vorzeit bis zum Untergange der Ordensherrschaft. 5 vols. Leipzig: Verlag von S. Hirzel, i 86 I- I 874.

Hirsch, Theodor., ed. “[Bernt Stegmann's] Hanseatische Chronik." In Scriptores Rerum Prussicarum. Die Geschichtsquellen der preussischer Vorzeit bis zum Untergange der Ordensherrschaft. vol. 5, 492-528. Leipzig: Verlag von S. Hirzel, i 874.

Hirsch, Theodor., ed. "Die Jüngere Hochmeisterchronik." In: Scriptores Rerum Prussicarum. Die Geschichtsquellen der preussischer Vorzeit bis zum Untergange der Ordensherrschaft. vol. 5, I-I 72. Leipzig: Verlag von S. Hirzel, I 874.

Hubatsch, Walther., Joachim, Erich., eds. Regesta historico-diplomatica Ordinis S. Mariae Theutonicorum IIg8-I525. Pars I., 3 vols. Göttingen: Vandenhoeck \& Ruprecht, 1950-1973. 
Jakubowski, Józef. Nauka Artyleryi. Zebrana z naypóźnieyszych Autorów napisana dla pożytku korpusu Artyleryi narodowey z Rozkazu i Naktadem Jego Królewskiej Mci. Pana Naszego Mitościwego. Warszawa: w Drukarni XX. Missyonarzów, I78 I-I 783. Joachim, Erich., ed. Das Marienburger Tresslerbuch der Jahre 1399-I409. Königsberg: Verlag von Thomas \& Oppermann, I 896.

Koczy, Leon., ed. Ksiega Theudenkusa. (Towarzystwo Naukowe w Toruniu. Fontes 33; Źródła do dziejów wojny trzynastoletniej I). Toruń: Nakładem Towarzystwa Naukowego w Toruniu, 1937.

Kopiński, Krzysztof., Mikulski, Krzysztof., Tandecki, Janusz., eds. Księga kamlarii miasta Torunia $z$ lat 1453-1495 / Kämmereibuch der Stadt Thorn von I453 bis I495. (Źródła do dziejów średniowiecznego Torunia / Quellen zur Geschichte des mittelalterlichen Thorn 3). Toruń: Wydawnictwo Naukowe Uniwersytetu Mikołaja Kopernika, 2007. Pelech, Markian., ed. Nowa ksiega rachunkowa Starego Miasta Elblaga. Part II (I4II-I4I4). (Towarzystwo Naukowe w Toruniu. Fontes 73). Warszawa: Państwowe Wydawnictwo Naukowe, 1989.

Pelech, Markian., ed. Nowa ksiega rachunkowa Starego Miasta Elblaga. Part I (I404-I4IO). (Towarzystwo Naukowe w Toruniu. Fontes 72). Warszawa: Państwowe Wydawnictwo Naukowe, 1987.

Perlbach, Max., ed. Die Preussischen Geschichtsschreiber des XVI. und XVII. Jahrbunderts. 5 vols. Leipzig: Verein für die Geschichte der Provinz Preussen, I 876-1998. Quarg, Götz., ed. Conrad Kyeser aus Eichstätt Bellifortis. c. I405. Dusseldorf: Verlag des Vereins Deutscher Ingenieure, 1967.

Saint Remy, Surirey de. Memoires d'artillerie. Recueillis par le Sr Surirey de Saint Remy, Commissaire Provincional de l'Artillerie, et l'un des Cent et un Officiers Privilegiez de ce Corps. Paris: Chez Jean Anisson Directeur de l'Imprimerie Royale, I 679.

Strehlke, Ernst., ed. “Johanns von Posilge, Officials von Pomesanien, Chronik des Landes Preussen (von I 360 an, fortgesetzt bis I 4 I 9 ) zugleich mit des auf Preussen bezuglichen Abschnitten aus der Chronik Detmar's von Lübeck." In Scriptores rerum Prussicarum. Die Geschichtsquellen der preussischer Vorzeit bis zum Untergange der Ordensherrschaft. vol. 3, I 3-399. Leipzig: Verlag von S. Hirzel, i 866.

Toeppen, Max., ed. "Die Ältere Hochmeisterchronik." In Scriptores rerum Prussicarum. Die Geschichtsquellen der preussischer Vorzeit bis zum Untergange der Ordensherrschaft. vol. 3, 5 19-709. Leipzig: Verlag von S. Hirzel, i 866.

Toeppen, Max., ed. "Geschichten von wegen eines Bundes von Landen und Steten wider den Orden unser Lieben Frawen und die Bruder desselben Ordens." In Scriptores rerum Prussicarum. Die Geschichtsquellen der preussischer Vorzeit bis zum Untergange der Ordensherrschaft. vol. 4, 7 I-2 I I, Leipzig: Verlag von S. Hirzel, i 870.

Toeppen, Max., ed. "Johann Lindaus Geschichte des dreizehnjaehrigen Krieges." In Scriptores rerum Prussicarum. Die Geschichtsquellen der preussischer Vorzeit bis zum Untergange der Ordensherrschaft. vol. 4, 490-675. Leipzig: Verlag von S. Hirzel, i 878. Toeppen, Max., ed. "Liborius Nakers Tagebuch über den Kriegszug des Hochmeisters Johann v. Tiefen gegen die Türken im J. I 497." In Scriptores rerum Prussicarum. Die 
Geschichtsquellen der preussischer Vorzeit bis zum Untergange der Ordensherrschaft. vol. 5, 289-3 i 4. Leipzig: Verlag von S. Hirzel, i 874.

Toeppen, Max., ed. Acten der Ständetage Preussens unter der Herrschaft des Deutschen Ordens. 5 vols. Leipzig: Verein für die Geschichte der Provinz Preussen, I 878- I 886.

Toeppen, Max., ed. "Elbinger Kriegsbuch”. Altpreussische Monatschrift 36 (1 889): 223$-273$.

Ziesemer, Walther., ed. Das Marienburger Konventsbuch der Jahre 1399-I412. Danzig: Druck und Verlag von A. W. Kafemann, I 9 I 3.

Ziesemer, Walther., ed. Das Ausgabebuch des Marienburger Hauskomturs I4IO-I420. Königsberg: Verlag von Thomas \& Oppermann, I 9 I I.

Ziesemer, Walther., ed. Das grosse Amterbuch des Deutschen Ordens. Danzig: Verlag und Druck von A. W. Kafemann G.M.B.H, i 92 I.

Ziesemer, Walther., ed. Das Marienburger Amterbuch (1375-1442). Danzig: Verlag und Druck von A. W. Kafemann G.M.B.H, i 916.

Arszyński, Marian., Sikorska-Ulfik, Izabela. “II. 2. 24. Büchsenkugeln.” In 800 Jahre Deutscher Orden. Ausstellung des Germanischen Germanisches Nationalmuseums Nürnberg in Zusammenarbeit mit der Internationalen Historischen Kommission zur Erforschung des Deutschen Ordens, edited by Udo Arnold, Gerhard Bott, 70-71. Gütersloh, München: Berthelsman Lexikon Verlag, I 990.

Baarmann, Oskar. "Die 'Faule Magd' der Königlichen Arsenalsammlung zu Dresden." Zeitschrift für Historische Waffenkunde 4 (1906-1908): 229-235.

Baltzer, Max. Zur Geschichte des Danziger Kriegswesens im I4. und I5. Jahrhundert. Ein Beitrag zur Säcularfeier der Vereinigung Danzigs mit der preussischen Monarchie. Wissenschaftliche Beilage zum Programm des Königlichen Gymnasiums zu Danzig. Danzig: A. Müller vormals Wedel'sche Hofbuchdruckerei, I 893.

Biskup, Marian. "Wykaz sprzętu artyleryjskiego Zakonu Krzyżackiego w Prusach z około I 523 roku." Komunikaty Mazursko-Warmińskie I-2/ I67-I 68 (I 984): 97-I 03.

Biskup, Marian. "Wykaz broni palnej i innego sprzętu wojennego wysyłanego przez Toruń w okresie wojny trzynastoletniej (I 454-1466).” Zapiski Historyczne 3 I, I (1966): $8 \mathrm{I}-94$.

Boeheim, Wendelin. "Studien über die Entwickelung des Geschützswesens in Deutschland." Zeitschrift für Historische Waffenkunde I,3 ( I 897-I 899): 57-6I.

Chodyński, Antoni R. “I.9.2. Bombarda krzyżacka z Kurzętnika, pocz. XV w." In Fundacje artystyczne na terenie państwa krzyżackiego w Prusach. Katalog wystawy w Muzeum Zamkowym w Malborku 25 czerwca - I2 września 2010 roku, edited by Barbara Pospieszna. Vol. I, I 26-I 27. Malbork: Muzeum Zamkowe w Malborku, 20 I o.

Chodyński, Antoni R. "Magazyny broni na zamku w Malborku w średniowieczu i w czasach nowożytnych. Muzealne zbiory militariów w XIX i XX w." In Materiaty z sesji naukowej z okazji 6olecia Muzeum Zamkowego w Pszczynie, II-I 2 maja 2006 r., edited by Maciej Kluss, i 8 I-200. Pszczyna: Muzeum Zamkowe w Pszczynie, 20 I o. 
Chodyński, Antoni R. “Bombarda krzyżacka z Kurzętnika.” In Imagines potestatis. Insygnia i znaki wtadzy w Królestwie Polskim i Zakonie Niemieckim. Katalog wystawy w Muzeum Zamkowym w Malborku 8 czerwca - 30 września 2007 roku, edited by Janusz Trupinda, 388-389. Malbork: Muzeum Zamkowe w Malborku, 2007.

Chodyński, Antoni R. "Inwentarz broni palnej w ratuszu elbląskim z I 4 I 3 roku." Rocznik Elbląski I 5 ( I 997): 69-79.

Chodyński, Antoni R. "The stores of arms in the town hall of Elbląg at the beginning of the $15^{\text {th }}$ century." Fasciculi Archaeologiae Historicae 9 ( 1996 ): I 5-24.

Chodyński, Antoni R. "Habsburg artillery at the close of the $15^{\text {th }}$ and the beginning of the I $6^{\text {th }}$ centuries." Fasciculi Archaeologiae Historicae 9 ( 1996 ): 5 I - 59.

Chodyński, Antoni R. Zbrojownie malborskie. Malbork: Muzeum Zamkowe w Malborku, I 978 .

Dąbrowska, Maria. "Proces odlewania dział w lejni malborskiej w XV wieku.” Archaeologia Historica Polona I 8 (2009): 2 I-44.

Dąbrowska, Maria. "Badania archeologiczno-architektoniczne na terenie Zamku Niskiego w Malborku w latach 1998-2004." In XV Sesja Pomorzoznawcza. Materiaty z konferencji 30 listopada-2 grudnia 2005 r., edited by Grażyna Nawrolska, 303-3 I 6. Elbląg: Muzeum Archeologiczno-Historyczne w Elblągu, 2007.

Ekdahl, Sven. "The Strategic Organization of the Teutonic Order in Prussia and Livonia." In La commanderie, institution des ordres militaires dans l'occident médiéval. (Archéologie et d'histoire de l'art I 4), edited by Anthony Luttrell, Léon Pressouyre, 2 I 9-242. Paris: Comité des travaux historiques et scientifiques, 2002.

Engel, Bernard. "Waffengeschichte-Studien aus dem Deutschordensgebiet." Zeitschrift für Historische Waffen-und Kostümkunde 4 (I 906-I 908): I I 8-I 25.

Engel, Bernard. "Nachrichten über Waffen aus dem Tresslerbuche des Deutschen Ordens von 1 399-1 409." Zeitschrift für Historische Waffenkunde I (1 897-1 899): 195-199, 228-233.

Eytelwein, Johann A. Vergleichungen der gegenwärtig und vormals in den königlich preußischen Staaten eingeführten Maaße und Gewichte mit Rücksicht auf die vorzüglichsten Maaße und Gewichte in Europa. Berlin: In der Realschulbuchhandlung, I 8 I 0.

Finó, Jean F. "L'artillerie en France à la fin du Moyen Âge." Gladius I 2 ( I 974): I 3-3 I.

Głosek, Marian. "Broń palna.” In Uzbrojenie w Polsce średniowiecznej I350-I450, edited by Andrzej Nadolski, I 55- I 64. Łódź: Polska Akademia Nauk, Instytut Historii Kultury Materialnej, 1990.

Goetz, Dorothea. Die Anfänge der Artillerie. Berlin: Militärverlag der Deutschen Demokratischen Republik, i 985.

Grodzicka, Maria. "Bombarda z zamku w Kurzętniku (Najstarszy spiżowy okaz artylerii krzyżackiej).” Studia do Dziejów Dawnego Uzbrojenia i Ubioru Wojskowego I (1963): 7-I 3 .

Grodzicka, Maria. “Zabytkowe działa spiżowe w zbiorach polskich.” Studia i Materiaty do Historii Wojskowości 6,2 (1960): 358-4I 5. 
Górski, Konstanty. Historia artyleryi polskiej. Warszawa: Skład Główny Księgarni E. Wende i S-ka, 1902.

Heckmann, Dieter. "Kriegstechnische Innovationen in den mittelalterlichen Deutschordenslanden Preussen und Livland." Militärgeschichtliche Zeitschrift 65 (2006): I 13 - I 29.

Heś, Robert. "Początki broni palnej w Zgorzelcu (Görlitz) I 393-I 420.” Acta Militaria Mediaevalia s (2009): I 37-I 46.

Jóźwiak, Sławomir., Trupinda, Janusz. Organizacja życia na zamku krzyżackim w Malborku w czasach wielkich mistrzów (1309-1457). Malbork: Muzeum Zamkowe w Malborku, 2007.

Klimek, Leszek., Stępiński, Janusz., Strzyż, Piotr., Żabiński, Grzegorz. "Late medieval wrought iron firearms from the Museum in Biecz." Fasciculi Archaeologiae Historicae 26 (2013): 83-98.

Kwiatkowski, Krzysztof. Wojska Zakonu Niemieckiego w Prusach I230-I525. Korporacje, jej pruskie wtadztwo, zbrojni, kultura wojny i aktywność militarna. (Dzieje Zakonu Niemieckiego 3). Toruń: Wydawnictwo Naukowe Uniwersytetu Mikołaja Kopernika, 2016.

Konieczny, Kazimierz. "Ręczna broń palna w Polsce w XV i XVI w.” Muzealnictwo Wojskowe 2 (1964): 167-237.

Makovskaya, Lidya K. Ručnoe ognestelnoye oruže russkoy armii konca XIV-XVII v. Moskva: Voennoe Izdatel'stvo, I 992.

McLachlan, Sean. Medieval handgonnes. The first black powder infantry weapons. (Osprey Weapon 3). Oxford: Osprey Publishing, 20 io.

Mielczarek, Mariusz. "Ręczna broń palna”. In Uzbrojenie w Polsce średniowiecznej I45o-I500, edited by Andrzej Nowakowski, 60-64. Toruń: Wydawnictwo Uniwersytetu Mikołaja Kopernika, 998.

Mielczarek, Mariusz. "Artyleria” In Uzbrojenie w Polsce średniowiecznej I450-Isoo, edited by Andrzej Nowakowski, 65-72. Toruń: Wydawnictwo Uniwersytetu Mikołaja Kopernika, 1998.

Możejko, Beata. "Ikonograficzne źródło do historii artylerii w drugiej połowie XV wieku”. Kwartalnik Historii Kultury Materialnej 48,3-4 (2000): I 7 I - I 76.

Müller, Heinrich. Deutsche Bronzegeschützrohre 1400-1750. Berlin: Deutscher Militärverlag, 1968.

Nowakowski, Andrzej. "Arsenał zamku krzyżackiego w Toruniu." In Materiaty z VII sesji naukowejUniwersyteckiego Centrum ArcheologiiŚredniowieczaiNowożytności(Archaeologia Historica Polona I 4), edited by Jerzy Olczak. 223-23 I. Toruń: Wydawnictwo Naukowe Uniwersytetu Mikołaja Kopernika, 2004.

Nowakowski, Andrzej. Arms and Armour in the Medieval Teutonic Order's State in Prussia. (Studies in the History of Ancient and Medieval Art of Warfare 2). Łódź: Oficyna Naukowa MS, I 994.

Nowakowski, Andrzej. "Źródła zaopatrzenia w uzbrojenie wojsk krzyżackich w Prusach w XIV-XV w." In Pamiętnik XIV Powszechnego Zjazdu Historyków Polskich, edited 
by Danuta Bednarska-Pituła. Vol. 2, 333-337. Toruń: Wydawnictwo Uniwersytetu Mikołaja Kopernika, I 994.

Nowakowski, Andrzej. "Some Remarks about Weapons stored in the Arsenals of the Teutonic Order's Castles in Prussia by the End of the $14^{\text {th }}$ and early $15^{\text {th }}$ Centuries." In Das Kriegswesen der Ritterorden im Mittelalter (Ordines Militares. Colloquia Historica Torunensia VII), edited by Zenon H. Nowak. 75-88. Toruń: Uniwersytet Mikołaja Kopernika, I 99 I.

Oakeshott, Ewart. European Weapons and Armour. From the Renaissance to the Industrial Revolution. Woodbridge: Boydell and Brewer, 2000.

Rathgen, Bernhard. Das Geschütz im Mittelalter. Berlin: VDI-Verlag GMBH, 928.

Rathgen, Bernhard. “Die Faule Grete." Elbinger Jabrbuch 4 (1 924): 45-76.

Rathgen, Bernhard, "Die Pulverwaffe im Deutschordensstaate von I 362 bis I 450 ." Elbinger Jabrbuch 2 ( I 922): I - I 6.

Schmidtchen, Volker. Die Feuerwaffen des Deutschen Ritterordens bis zur Schlacht bei Tannenberg I4Io: Bestände, Funktion und Kosten, dargestellt anhand der Wirtschaftsbücher des Ordens von 1374 bis 1410 . Lüneburg: Nordostdeutsches Kulturwerk, I 977.

Serdon-Provost, Valerie. "The constitution of artillery parks and fortifications for defending. The dukes of Lorraine in Nancy: a case study." In Weapons Bring Peace? Warfare in Medieval and Early Modern Europe (Wratislavia Antiqua i 8), edited by Lech Marek. I 89- I 98. Wrocław: Uniwersytet Wrocławski, 20 I 3.

Smith, Robert D., DeVries, Kelly. The Artillery of the Dukes of Burgundy, 1363-1477. Woodbridge: Boydell and Brewer, 2005.

Smith, Robert D., Brown, Ruth R. Bombards Mons Meg and Her Sisters. (Royal Armouries Monograph I ). London: Trustees of the Royal Armouries, I 989.

Steinbrecht, Conrad. Das Bawwesen der Komturei Marienburg in den Jabren I4IO-I420. Separat-Abdruck aus dem Ausgabebuch des Marienburger Hauskomturs herausgegeben von Dr. W. Ziesemer. Königsberg: Verlag von Thomas \& Oppermann, I 9 I I.

Stępiński, Janusz., Żabiński, Grzegorz., Strzyż, Piotr. “The light field cannon from Kurzętnik - a unique example of medieval artillery (against the background of development of firearms in the Teutonic Order's state in Prussia)". Acta Militaria Mediaevalia 9 (2013): 155-202.

Strzyż, Piotr. Broń palna w Europie Środkowej $w X I V-X V w$. Łódź: Instytut Archeologii i Etnologii PAN, 20 I 4.

Strzyż, Piotr. Średniowieczna broń palna w Polsce. Studium archeologiczne. Łódź: Instytut Archeologii i Etnologii PAN, 20 I I.

Strzyż, Piotr. "Pociski do średniowiecznej broni palnej z pogranicza polsko-krzyżackiego." In Arma et Medium Aevum. Studia nad uzbrojeniem średniowiecznym, edited by Paweł Kucypera, Piotr Pudło, Grzegorz Żabiński, I 98-223. Toruń: Wydawnictwo Adam Marszałek, 2009.

Strzyż, Piotr. "Zespół kamiennych kul działowych z zamku w Reszlu." Komunikaty Mazursko-Warmińskie 4/258 (2007): 46 I-470. 
Strzyż, Piotr., Czubla, Piotr., Mackiewicz, Adam. "Cannonballs from the Olsztyn turret." Fasciculi Archaeologiae Historicae 28 (2015) (From the Problems of Historical Archaeology): I $23-$ I 3 I.

Świętosławski, Witold. “Koszt broni palnej i jej użycia w państwie krzyżackim w Prusach na początku XV wieku." Studia i Materiaty do Historii Wojskowości 35 (1 993): I 9-3 I.

Szymczak, Jan. Początki broni palnej w Polsce I383-I533. Łódź: Wydawnictwo Uniwersytetu Łódzkiego, 2004.

Szymczak, Jan. "Broń palna w arsenałach zamkowych i miejskich w Polsce XV wieku." In Szlachta, starostowie, zaciężni (Gdańskie Studia z Dziejów Średniowiecza 5), edited by Błażej Śliwiński, 28 I-299. Gdańsk, Koszalin: Bałtycka Wyższa Szkoła Humanistyczna, I 998.

Szymczak, Jan. "Die Feuerwaffenvorräte in den Schloß- und Stadtarsenalen in Polen in der 2. Hälfte des i 5. und am Anfang des i6. Jahrhunderts." Fasciculi Archaeologiae Historicae 9 ( I 996): 9-I 4.

Thierbach, Max. "Über die erste Entwickelung der Handfeuerwaffen.” Zeitschrift für Historische Waffenkunde I, 6 ( I 897-I 899): I 29-1 33.

Toeppen, Max. "Die älteste Nachrichten uber das Geschützwesen in Preussen." Archiv für Offiziere des Königlichen Preussischen Artillerie- und Ingenieure Corps 63 ( I 868): I 23-I 68, 2 I I-236.

Wasilewski Artur. "Późnośredniowieczne kule artyleryjskie znalezione na zamku w Pucku." Zapiski Puckie 3 (2004): I 48-I 52.

Williams, Alan R., Paterson, A. J. R. "A Turkish bronze cannon in the Tower of London." Gladius I 7 ( I 986): I 85-205.

Woźniak, Michał. “II. 2. 23. Bombarde." In 800 Jahre Deutscher Orden. Ausstellung des Germanischen Germanisches Nationalmuseums Nürnberg in Zusammenarbeit mit der Internationalen Historischen Kommission zur Erforschung des Deutschen Ordens, edited by Udo Arnold, Gerhard Bott, 70. Gütersloh, München: Berthelsman Lexikon Verlag, I 990.

Żabiński, Grzegorz. "Technology of manufacture of firearms in the Teutonic Order's state in Prussia - gun barrels and metal projectiles." Fasciculi Archaeologiae Historicae 28 (20 I 5) (From the Problems of Historical Archaeology): 83- I I 0.

Żabiński, Grzegorz. "Ways of acquisition of firearms and related equipment in the state of the Teutonic Order in Prussia." Acta Militaria Mediaevalia ro (20 I 4): I I 9- I 42.

Żabiński, Grzegorz. "Das Grosse Amterbuch des Deutschen Ordens - remarks on its value for arms and armour research." In Weapons Bring Peace? Warfare in Medieval and Early Modern Europe (Wratislavia Antiqua I 8), edited by Lech Marek. I 99-2 I 2. Wrocław: Uniwersytet Wrocławski, 20 I 3.

Żabiński, Grzegorz. “The Grose bochse - a Teutonic Supergun from I 408.” Fasciculi Archaeologiae Historicae 25 (201 2): 3 I -40.

Żabiński, Grzegorz. "Das Marienburger Ämterbuch as a source for the Teutonic Order's arms and armour resources." In Non sensistis gladios. Studia ofiarowane Marianowi Gtoskowi w 7o. rocznice urodzin, edited by Olgierd Ławrynowicz, Jerzy Maik, Piotr 
A. Nowakowski, 505-514. Łódź: Instytut Archeologii Uniwersytetu Łódzkiego, 2011.

Żabiński, Grzegorz., Muntowski, Patryk. "Średniowieczne i wczesnonowożytne militaria z wału von Plauena na Zamku w Malborku.” In XVIII Sesja Pomorzoznawcza, vol. 2: Od późnego średniowiecza do czasów nowożytnych. Materiaty z konferencji I 6-I 8 listopada 20II, edited by Ewa Fudzińska, 37-58. Malbork: Muzeum Zamkowe w Malborku, 2013.

\section{Abstract \\ Not Only Barrels - Equipment for Firearms in the State of the Teutonic Order in Prussia}

The study focuses on equipment for firearms in the state of the Teutonic Order in Prussia in the Middle Ages and the Early Modern Period. The paper is chiefly based on written sources, both concerning the Order itself (mainly account books, inventories and visitation reports) and those related to Prussian towns (chiefly account books). In some cases relevant pieces of information could also be retrieved from narrative sources. For the sake of comparison, data from contemporary and later manuscripts on firearms was consulted. The first issue which is dealt with are stocks for hand-held firearms and trestles, stands and carriages for artillery. In many cases it is possible to offer a closer identification of kinds of gun beds, trestles and carriages. Then, gun instruments are discussed: charging ladles, ramrods, linstocks, and the like, as well as various kinds of containers for gunpowder, projectiles and tools for firearms. Regrettably, it is only in exceptional cases that it is possible to relate discussed equipment to a particular gun. A separate section is devoted to the analysis of tools which were used in the manufacture of projectiles and gunpowder. In spite of all the limitations resulting from the nature of consulted sources, it is possible to offer a reasonable image of equipment which accompanied firearms in the Order's state. 
[223]

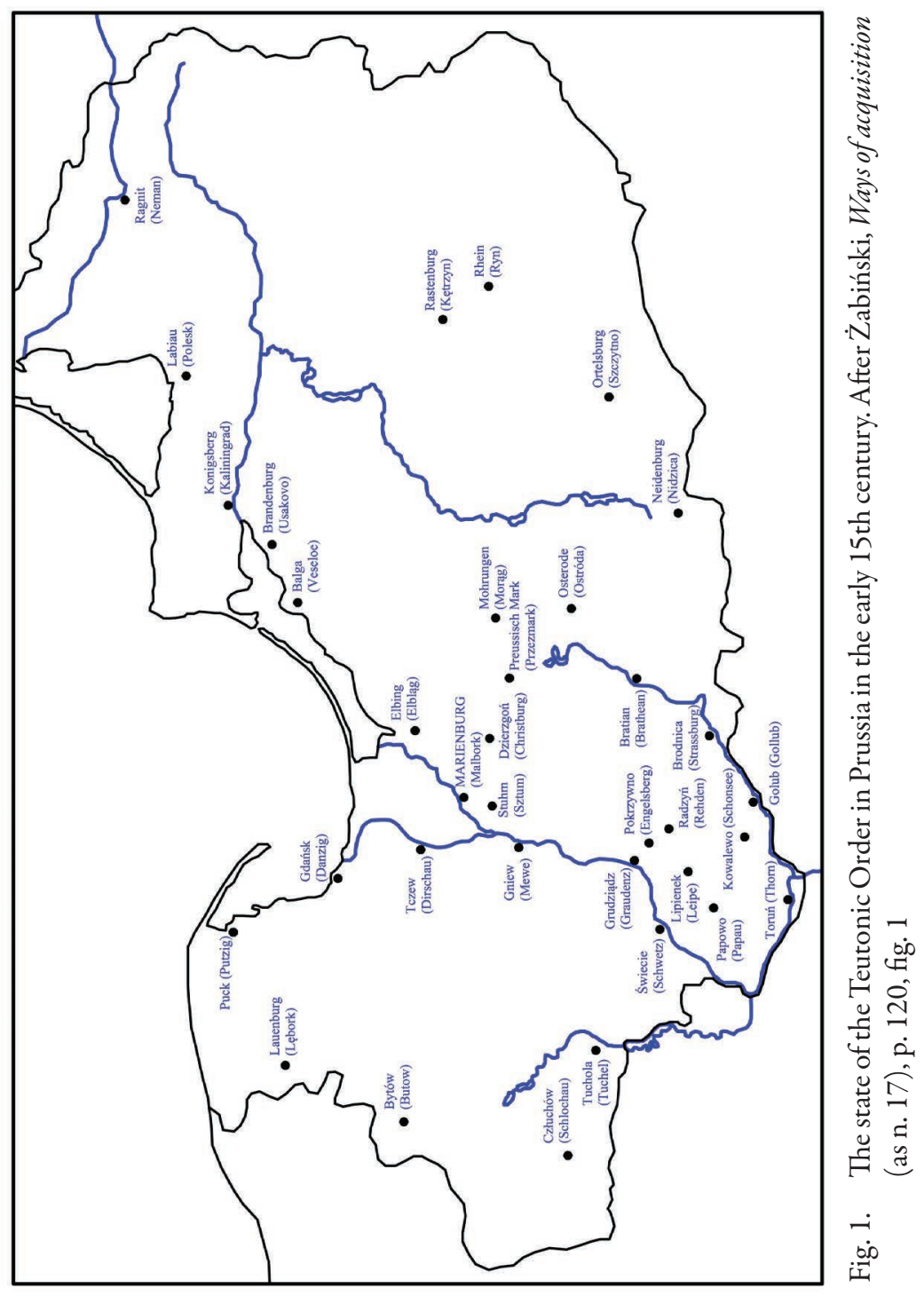



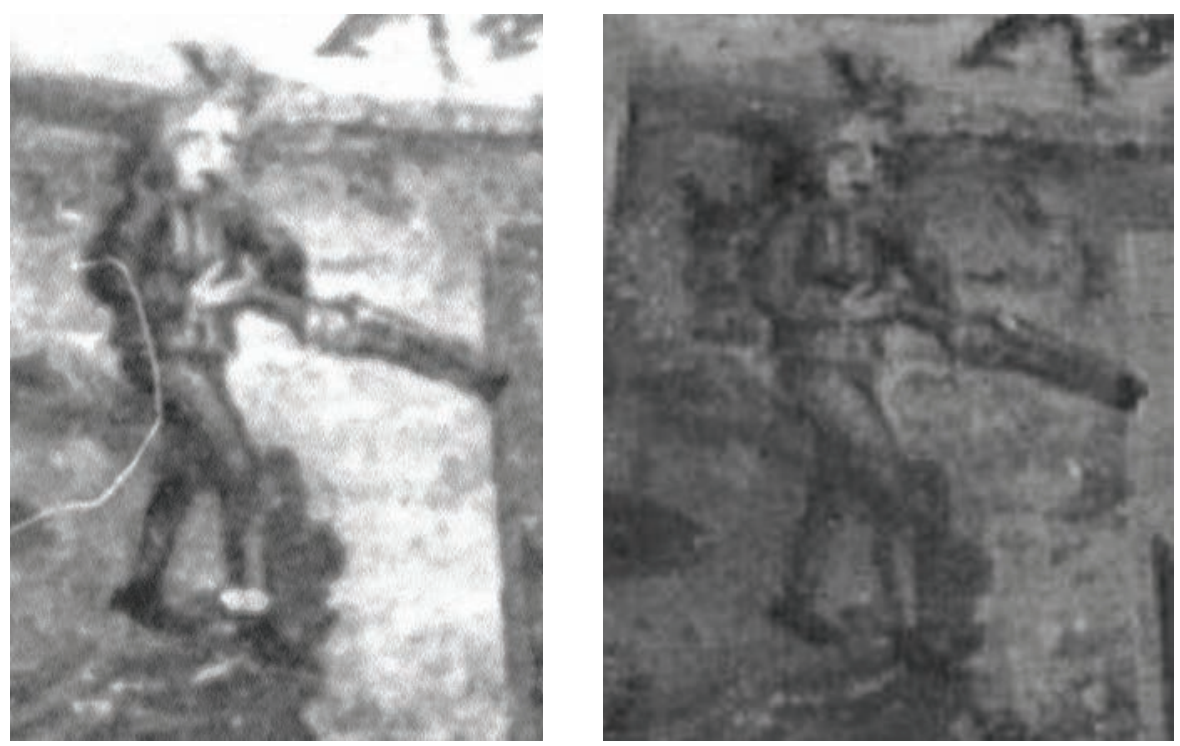

Fig. 2. Danzig (Pol. Gdańsk) soldier with a handbuchse depicted in a painting "Siege of Marienburg (Malbork) in 1460" (c. 1480). A short barrel is mounted on a stock with a butt. Photocopy in the collection of the Institute of Archaeology of the Polish Academy of Sciences, Łódź Branch

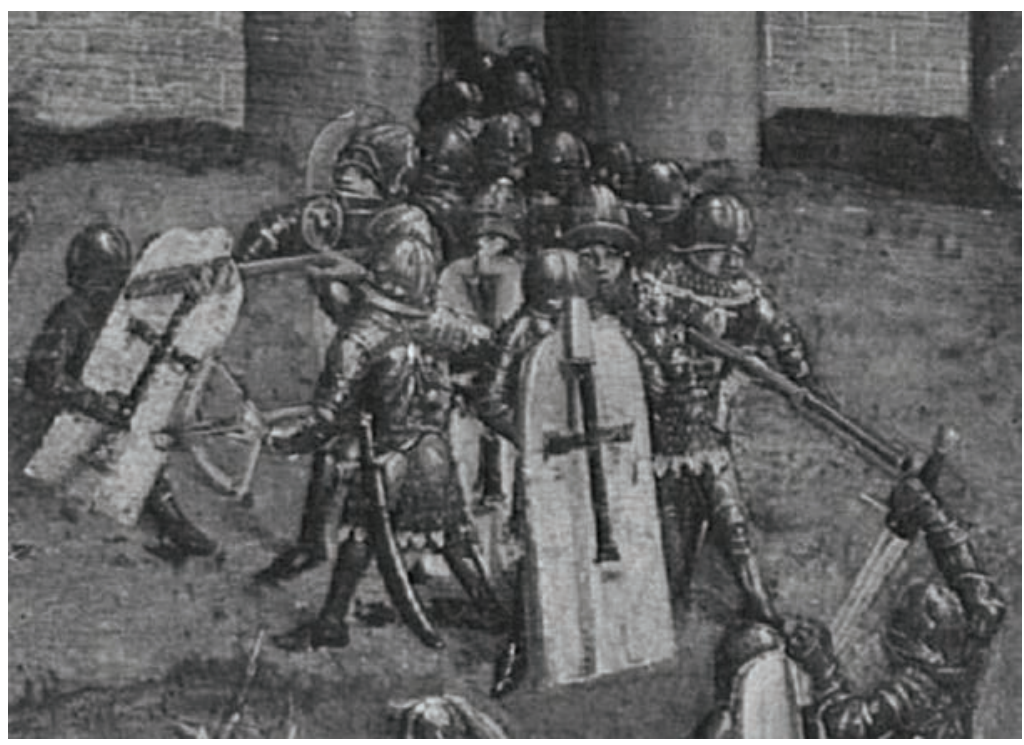

Fig. 3. Teutonic soldiers with handbuchsen. "Siege of Marienburg (Malbork) in 1460" (c. 1480). Photocopy in the collection of the Institute of Archaeology of the Polish Academy of Sciences, Łódź Branch 

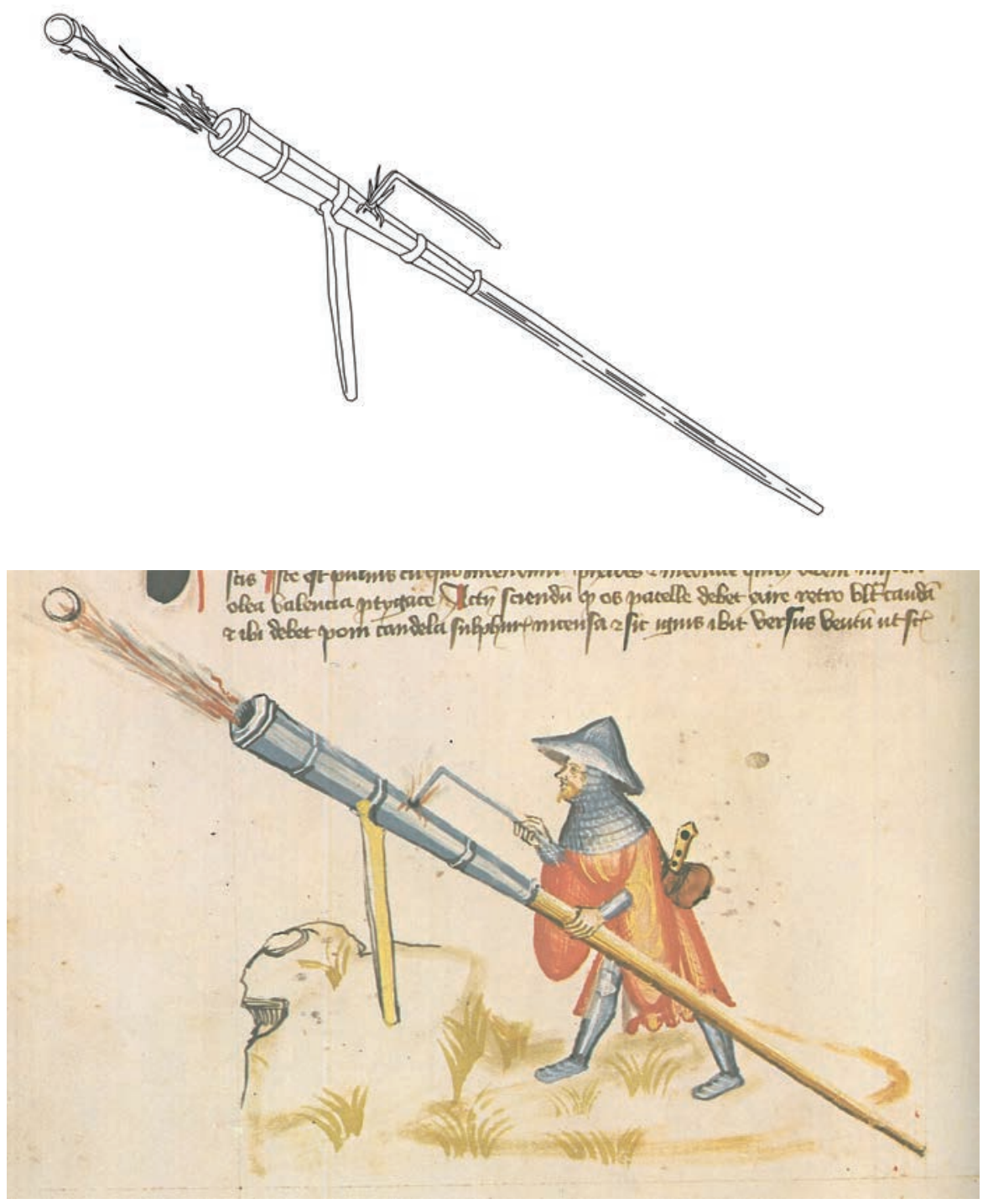

Fig. 4. Early handbuchse. After Kyeser (as n. 39), fol. 103v. Afterdrawing G. Żabiński 


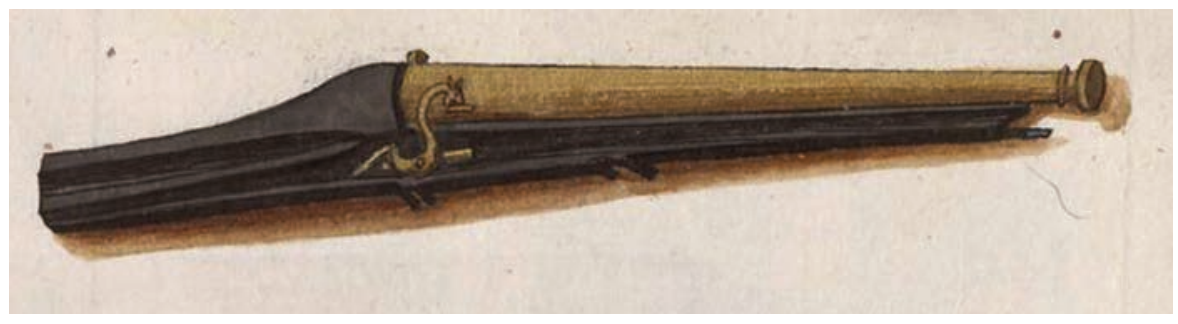

Fig. 5. Handbuchse with a matchlock. A partially hidden ramrod can be seen in the front part of the stock. After Zeugbuch (as n. 42), fol. 166r. @ Bayerische Staatsbibliothek München

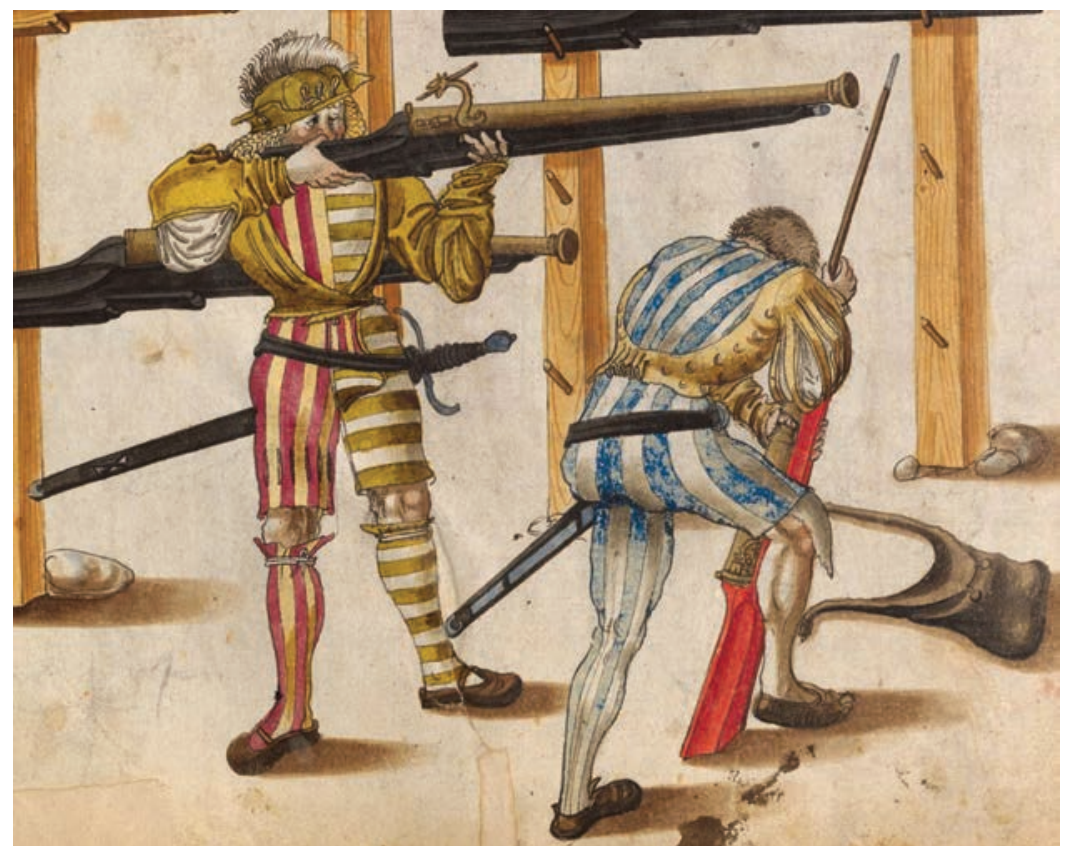

Fig. 6. Landsknechts with messing hanndtbüchsen equipped with matchlocks. Ramrods and a leather bag can be seen. After Zeugbuch (as n. 42), fol. 61r. (c) Bayerische Staatsbibliothek München 

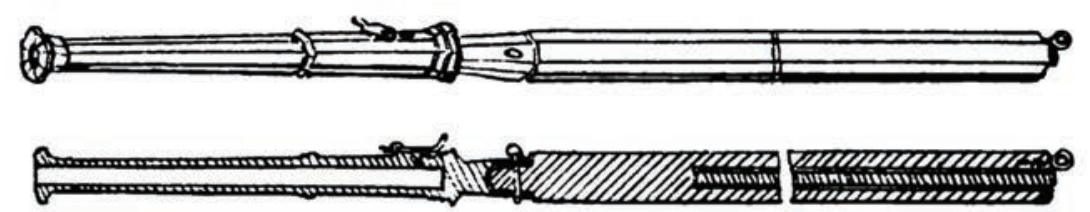

Fig. 7. Handbuchse from the Curonian Spit, early $15^{\text {th }}$ century. After Thierbach (as n. 54), p. 130, fig. 4

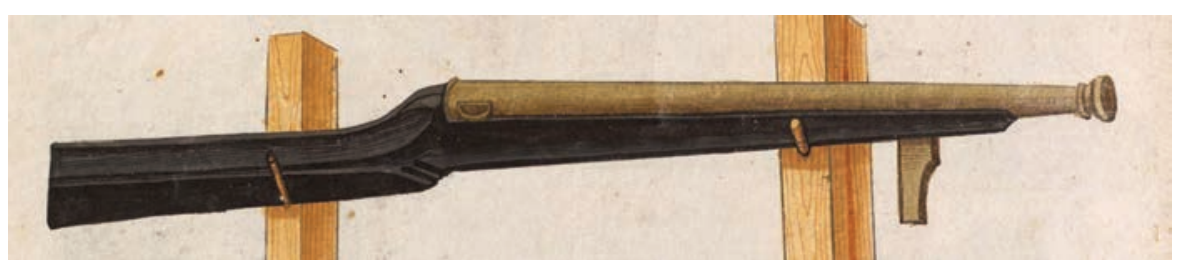

Fig. 8. Messing hagkennpuchse. There is a priming pan on the right side of the barrel. After Zeugbuch (as n. 42), fol. 72v. ( Bayerische Staatsbibliothek München 


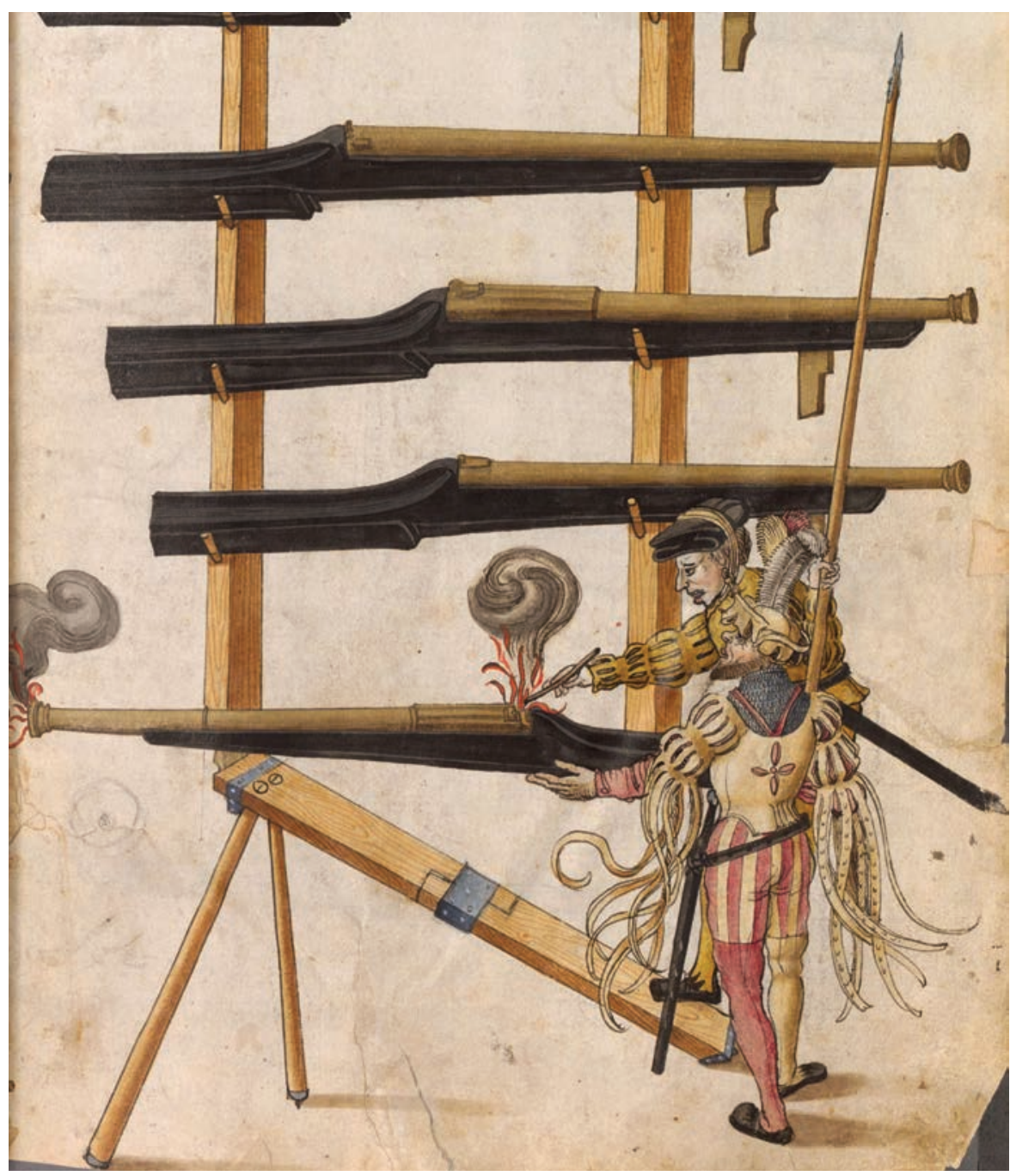

Fig. 9. Heavy brass hackbut on a wooden trestle. The gunpowder charge is ignited with a match. After Zeugbuch (as n. 42), fol. 72r. () Bayerische Staatsbibliothek München 


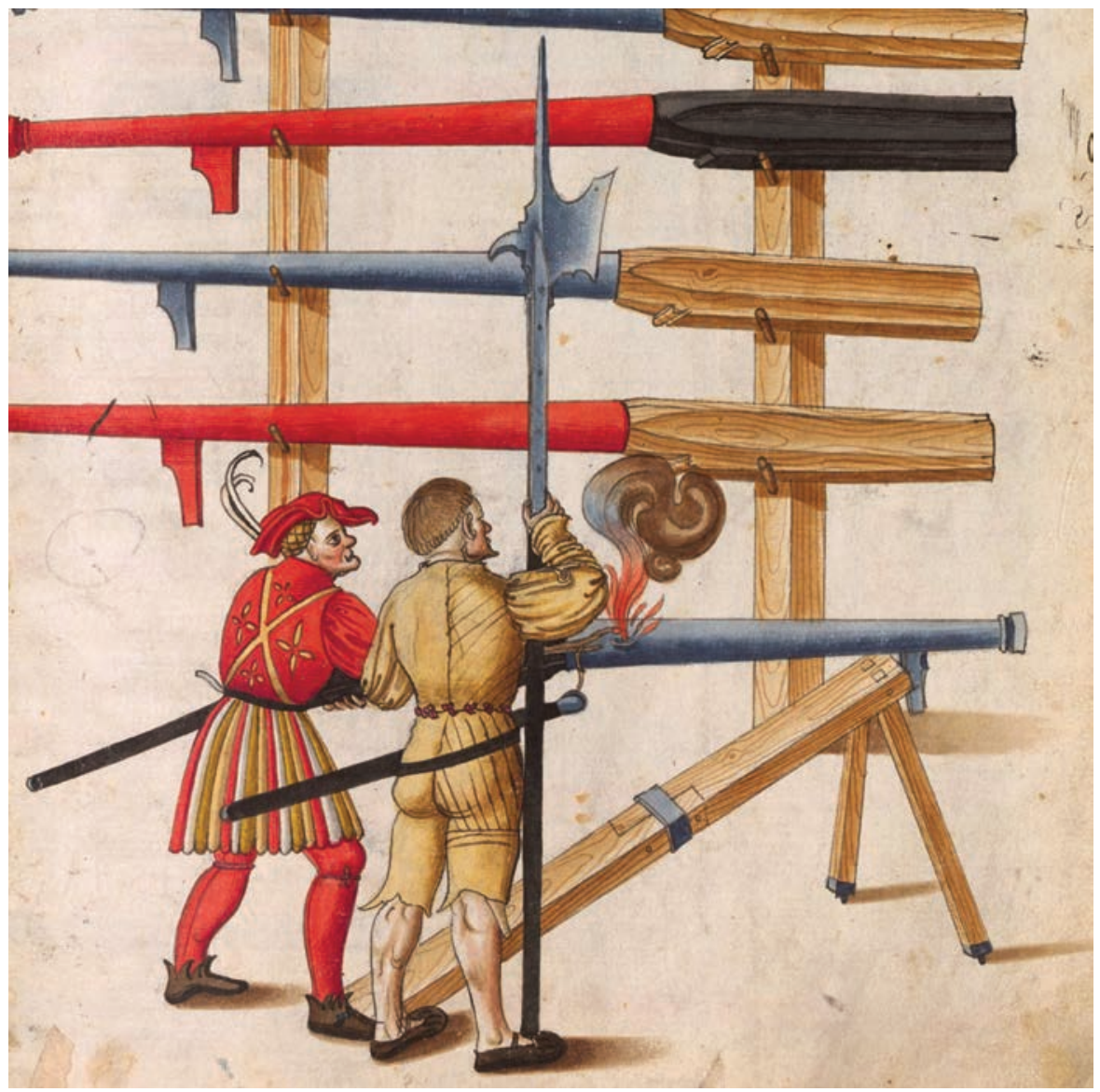

Fig. 10. Iron-forged hackbut. The gun is supported on a wooden trestle and the gunpowder charge is ignited with a match. A priming pan can be seen on the right side of the barrel. After Zeugbuch (as n. 42), fol. 73r. ( ) Bayerische Staatsbibliothek München 


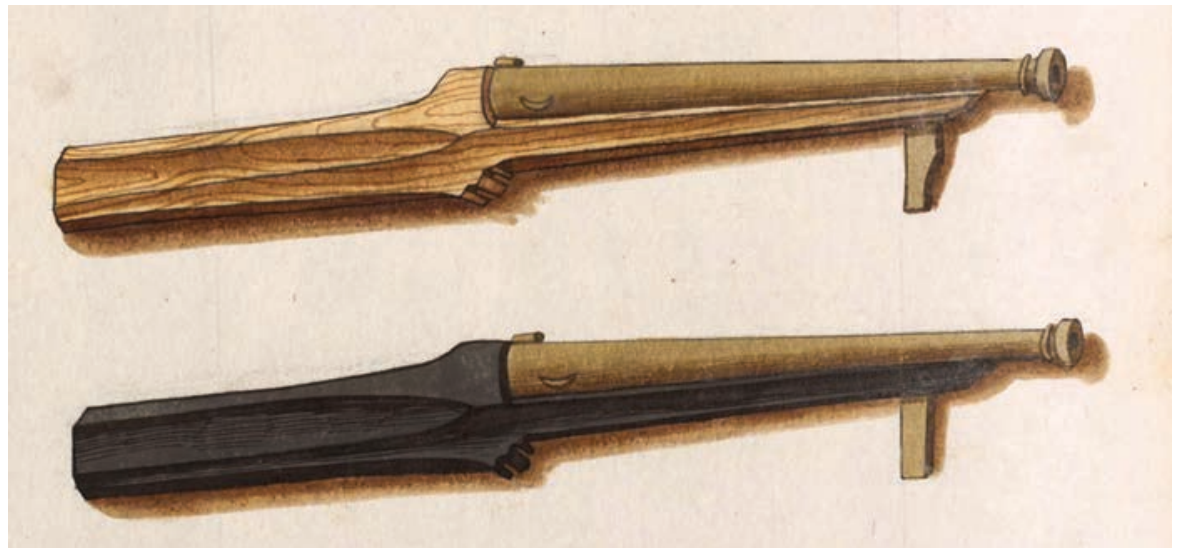

Fig. 11. Hackbuts in stocks with butts. Priming pans can be seen on the right side of barrels. After Zeugbuch (as n. 42), fol. 122r. (@) Bayerische Staatsbibliothek München

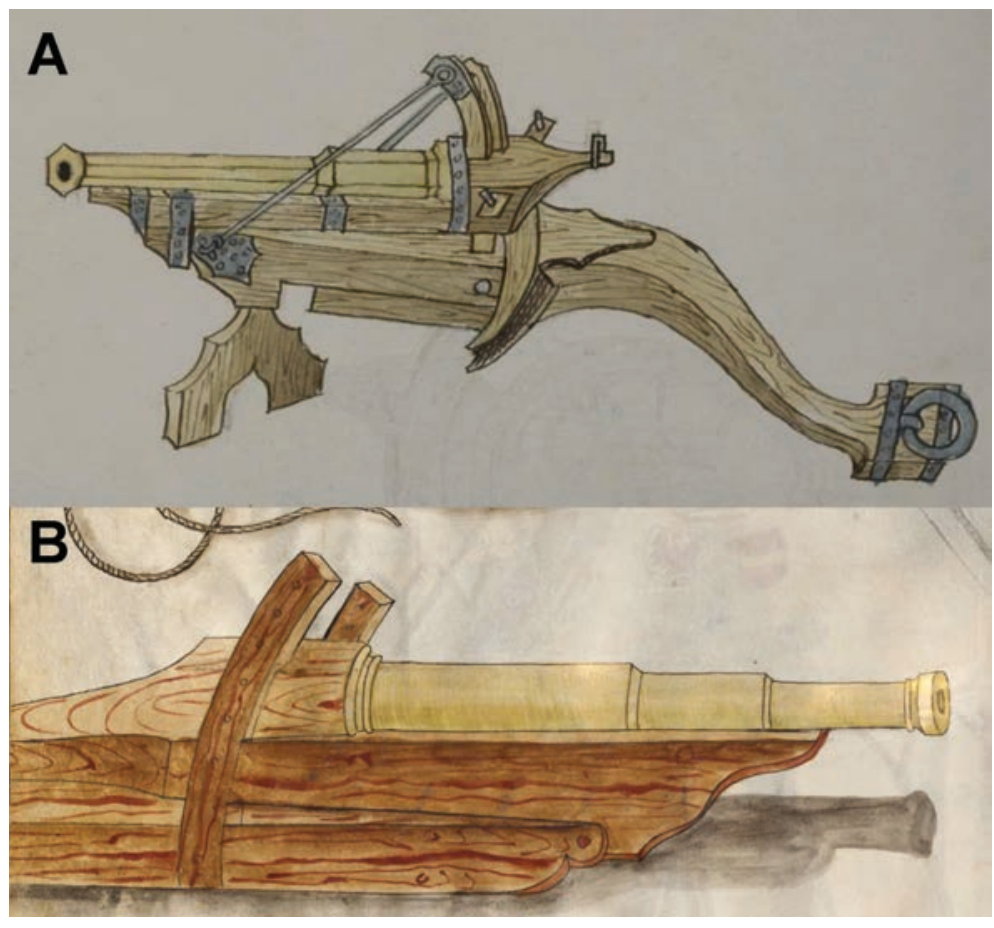

Fig. 12. Light guns on trestles. Both are equipped with split-trail elevation devices (socalled aiming brackets)

A - after Mönch (as n. 4I), fol. 24 r. (C) Universitätsbibliothek Heidelberg

B - after Zeugbuch (as n. 42), fol. 23v. @ Bayerische Staatsbibliothek München 


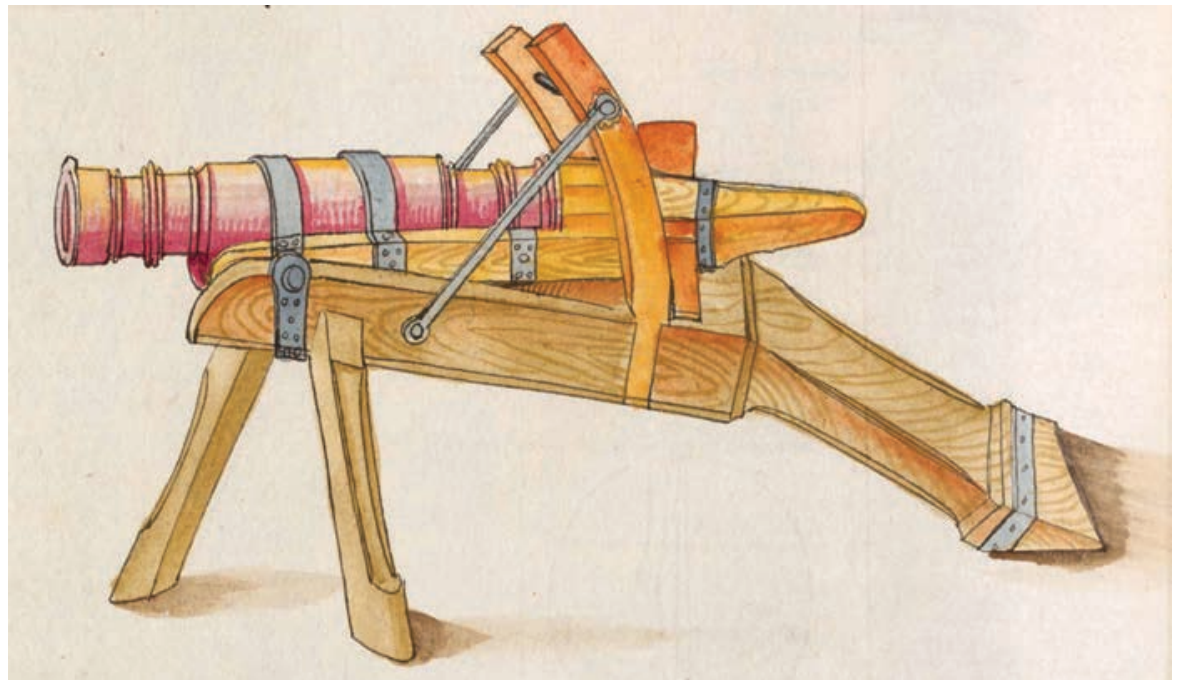

Fig. 13. Terrace-gun on a trestle. The gun is equipped with a split-trail elevation. Iron fittings attaching the barrel to the bed are visible. After Zeugbuch (as n. 42), fol. 171v. @ Bayerische Staatsbibliothek München

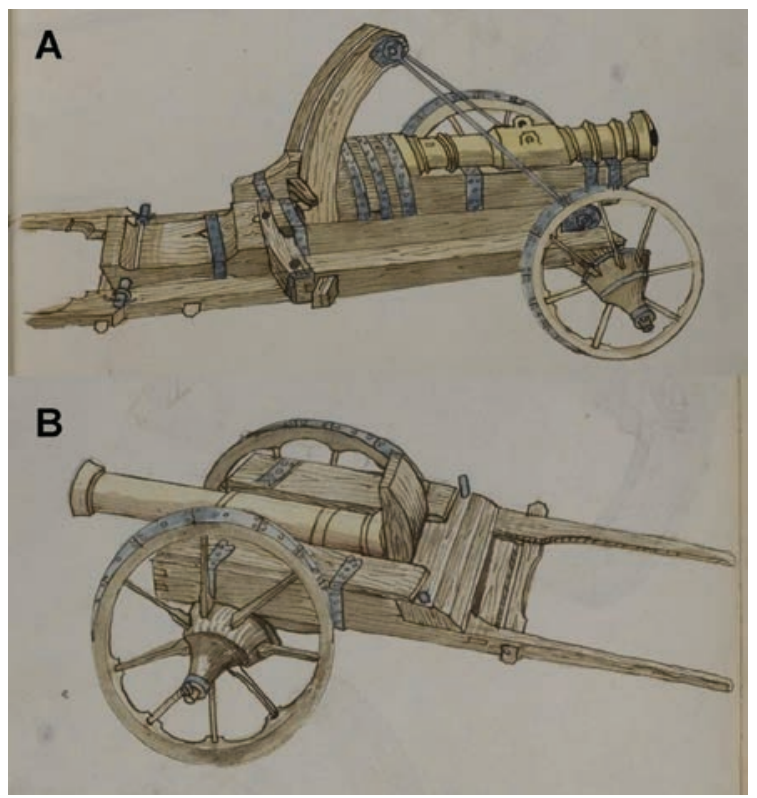

Fig. 14. Light cannons on carriages

A - after Mönch (as n. 4I), fol. 23r. A split-trail elevation device can be seen. () Universitätsbibliothek Heidelberg

B - after Mönch (as n. 4I), fol. 23v. @ Universitätsbibliothek Heidelberg 


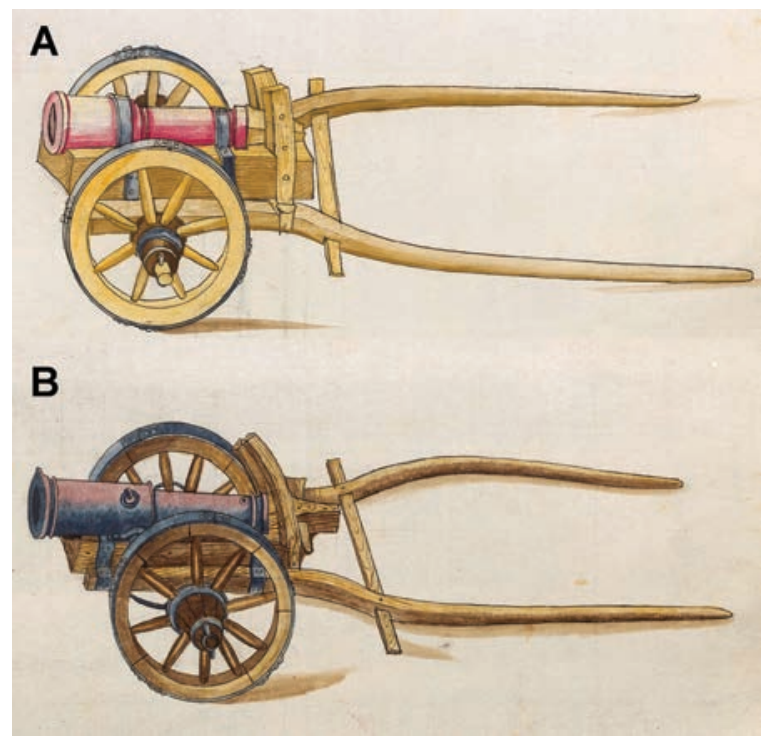

Fig. 15. Field guns on carriages

A - after Zeugbuch (as n. 42), fol. I 87v. (C) Bayerische Staatsbibliothek München

B - after Zeugbuch (as n. 42), I 502, I 88v. (C) Bayerische Staatsbibliothek München

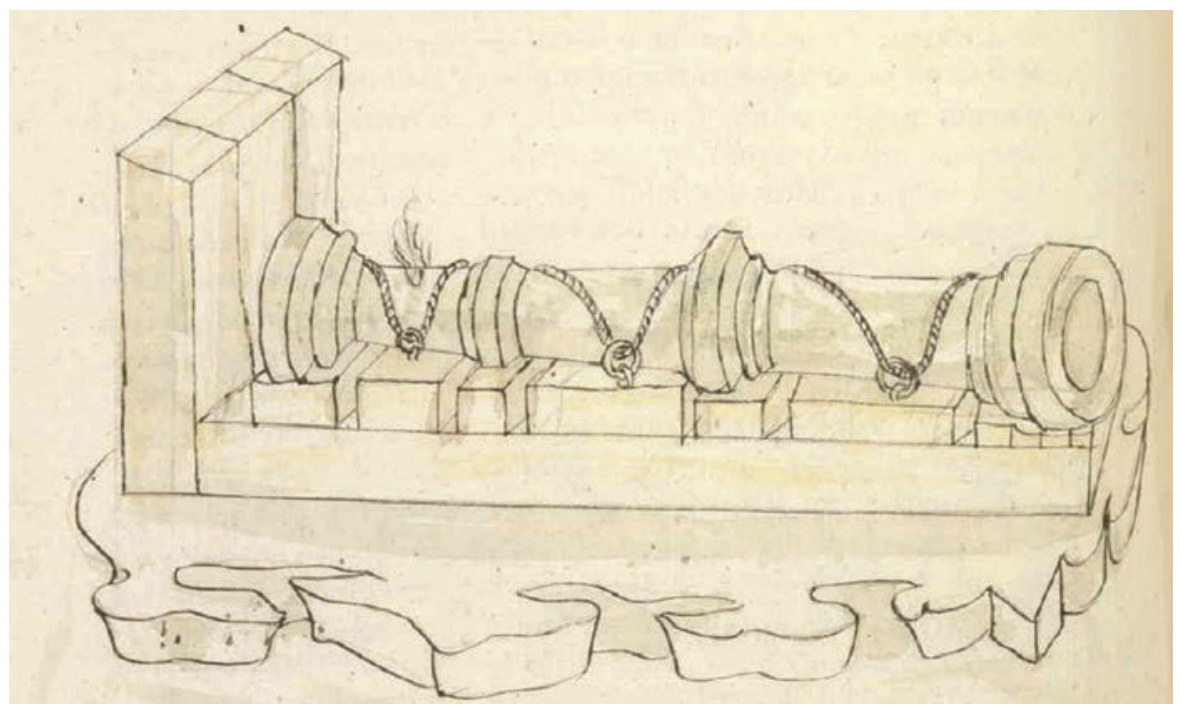

Fig. 16. Heavy gun on an immovable stand. The barrel is attached to the bed with a rope and rings. After R. Valturio, De re militari, c. 1460, fol. 122v. Rosenwald Collection, Rare Books and Special Collections Division of the Library of Congress, Washington, DC 


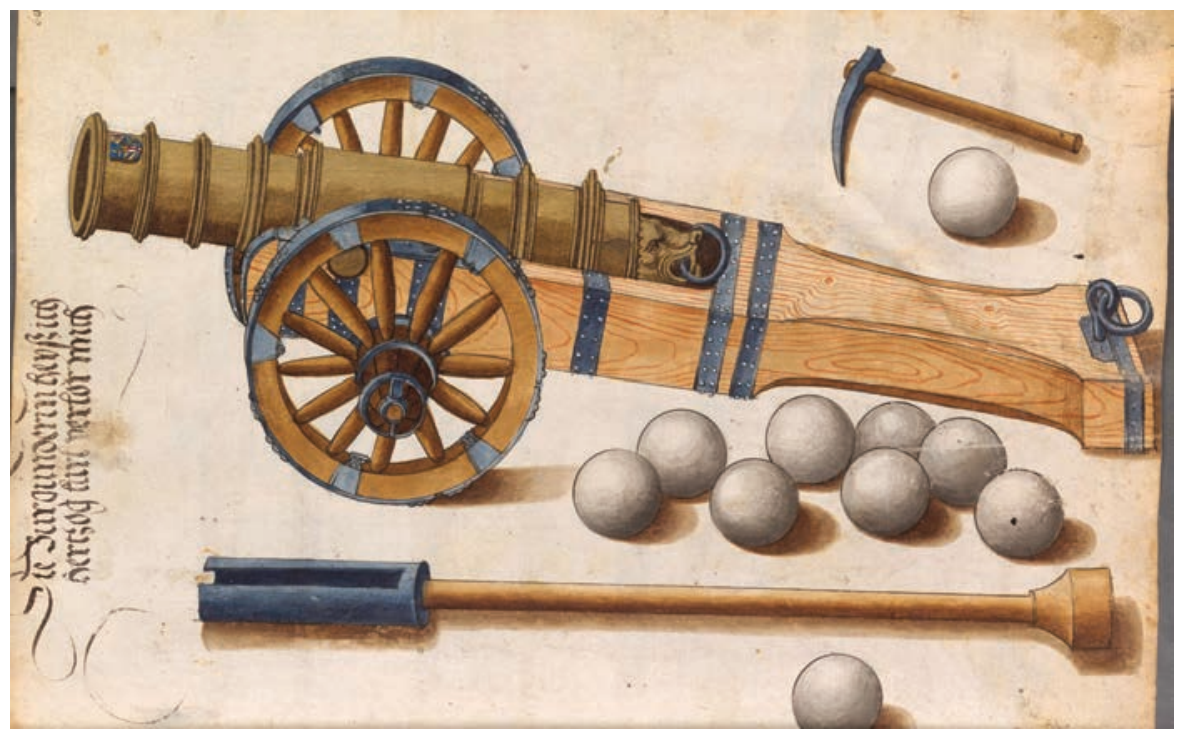

Fig. 17. Heavy gun on a carriage - the Burgunderin of Charles the Bold of Burgundy (died 1477). Next to the cannon there is a charging ladle with a ramrod and a pick. After Zeugbuch (as n. 42), fol. 60r. @ Bayerische Staatsbibliothek München 


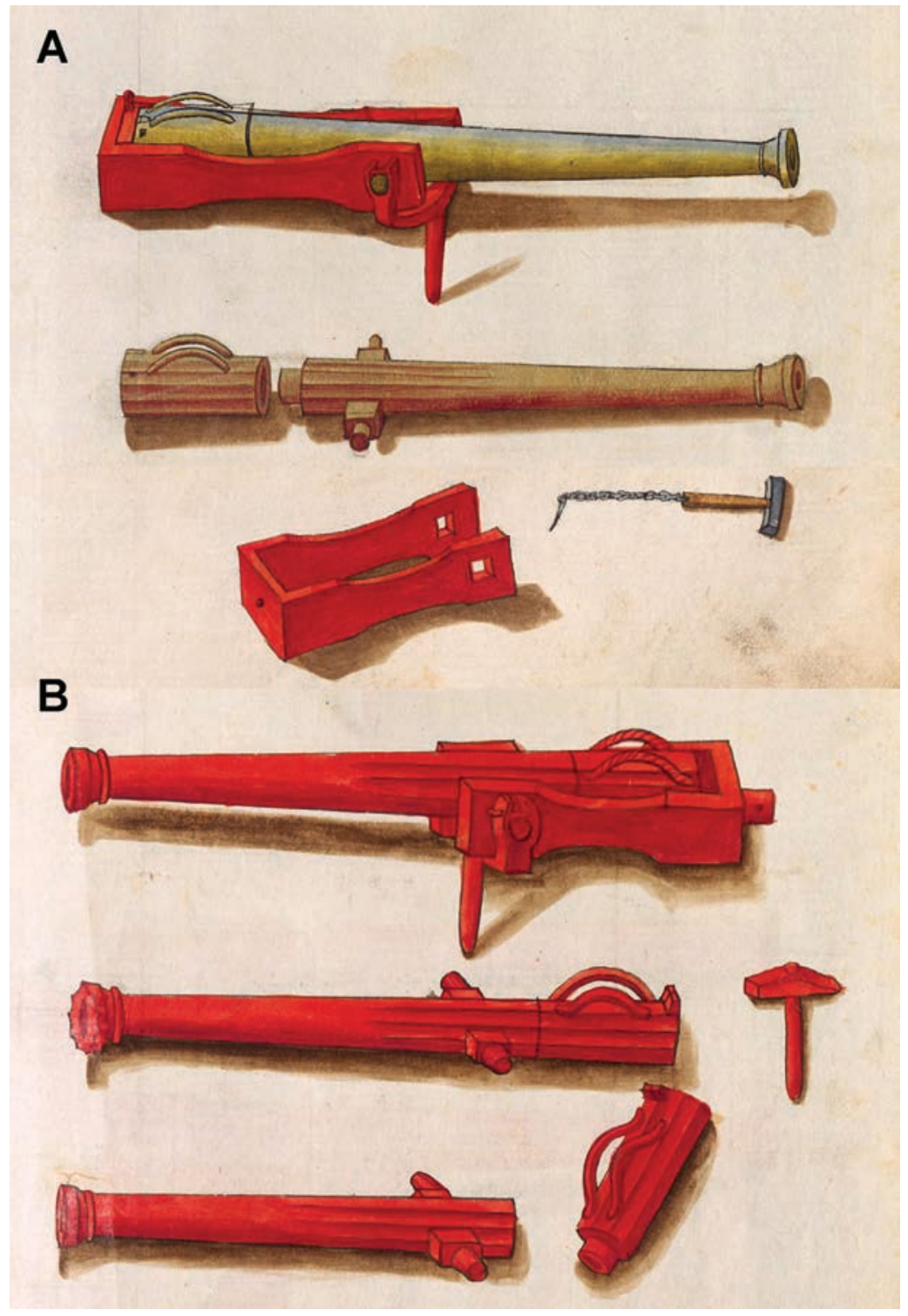

Fig. 18. Naval guns

A - cast veuglaires (gossen camerslanngen). Behind chambers there are wooden wedges on chains. These wedges were intended to thicken the chamber in the barrel. There is also a hammer for beating the wedge behind the chamber. After Zeugbuch (as n. 42), fol. 63r. ๑ Bayerische Staatsbibliothek München

B - iron-forged veuglaires (geschmidt eysne camerslangen). After Zeugbuch (as n. 42), fol. 68r. @ Bayerische Staatsbibliothek München 


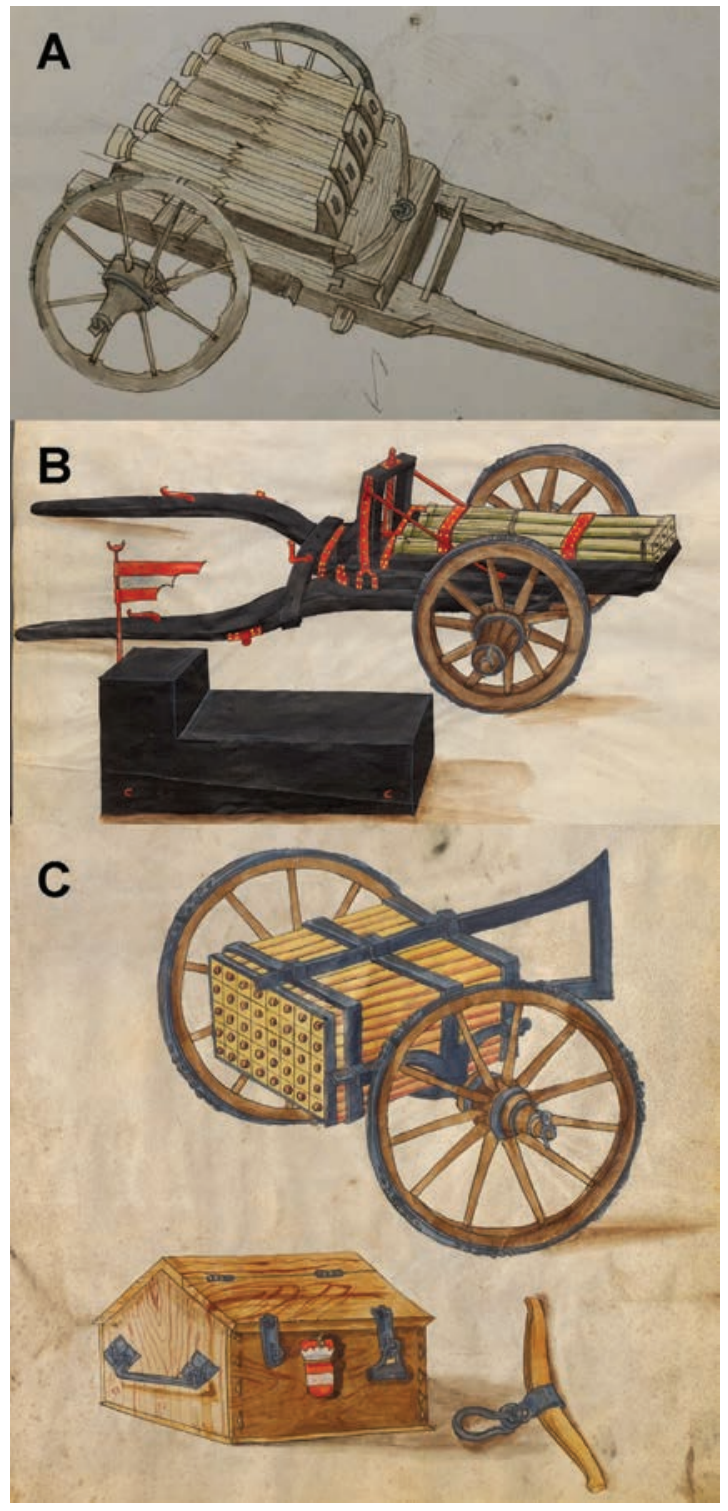

Fig. 19. Organ guns on carriages

A - after Mönch (as n. 4I), fol. 28r. (c) Universitätsbibliothek Heidelberg

$\mathrm{B}$ - the gun is equipped with a screw elevation device. Numerous iron fittings and iron rims on wheels can be seen. After Zeugbuch (as n. 42), fol. r 8r. (c) Bayerische Staatsbibliothek München

C - a chest with equipment and a yoke can be seen. After Zeugbuch (as n. 42), fol. 26r. (C) Bayerische Staatsbibliothek München 


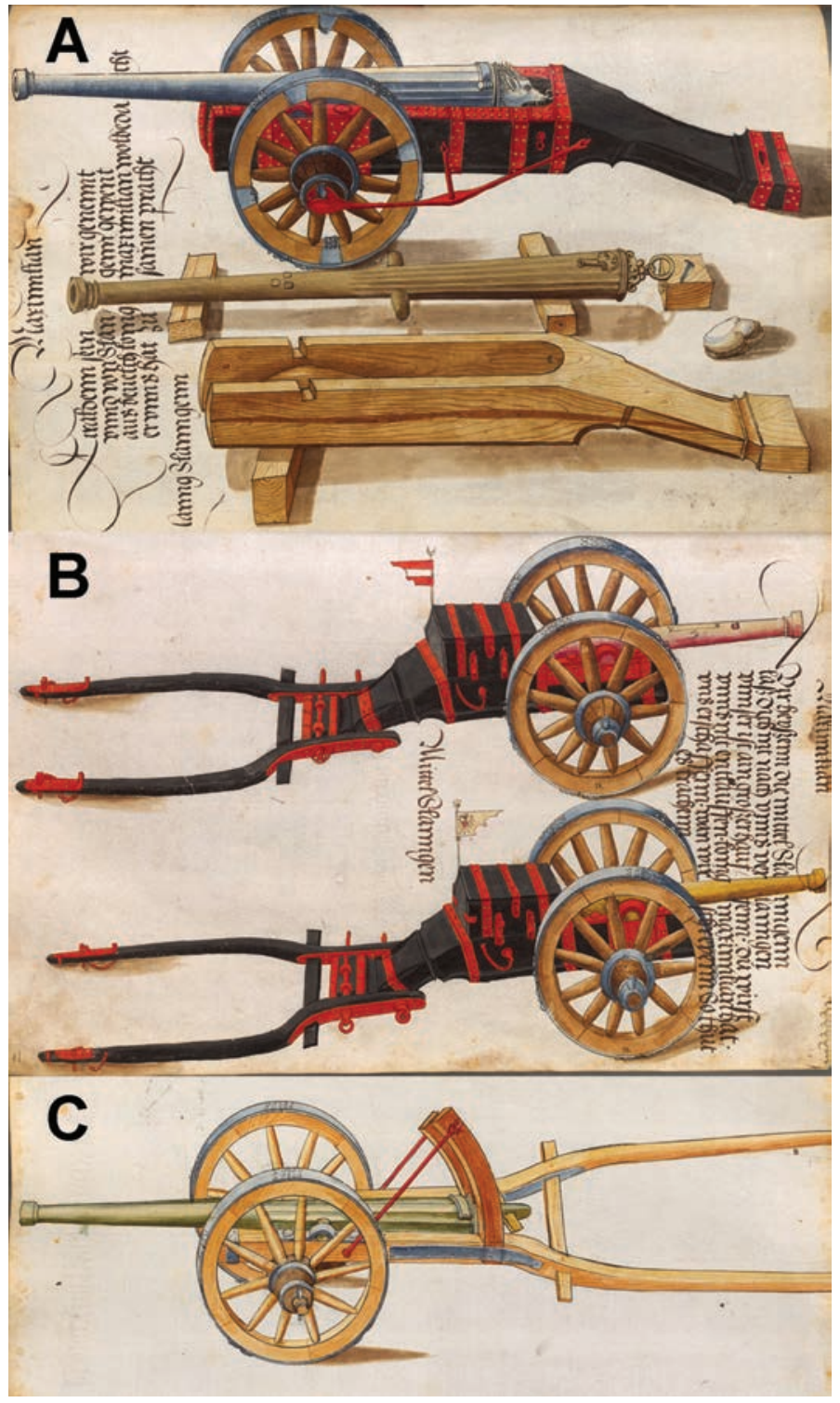

Fig. 20. Different types of schlangen

A - lanng slanngen on carriages. After Zeugbuch (as n. 42), fol. 5 Iv. (C) Bayerische Staatsbibliothek München

B - mittel slanngen on carriages. Iron-fitted chests are transported on the carriages. After Zeugbuch (as n. 42), fol. 54r. (C) Bayerische Staatsbibliothek München

C - light schlange on the carriage with an aiming bracket. After Zeugbuch (as n. 42), fol. I 89r. (C) Bayerische Staatsbibliothek München 


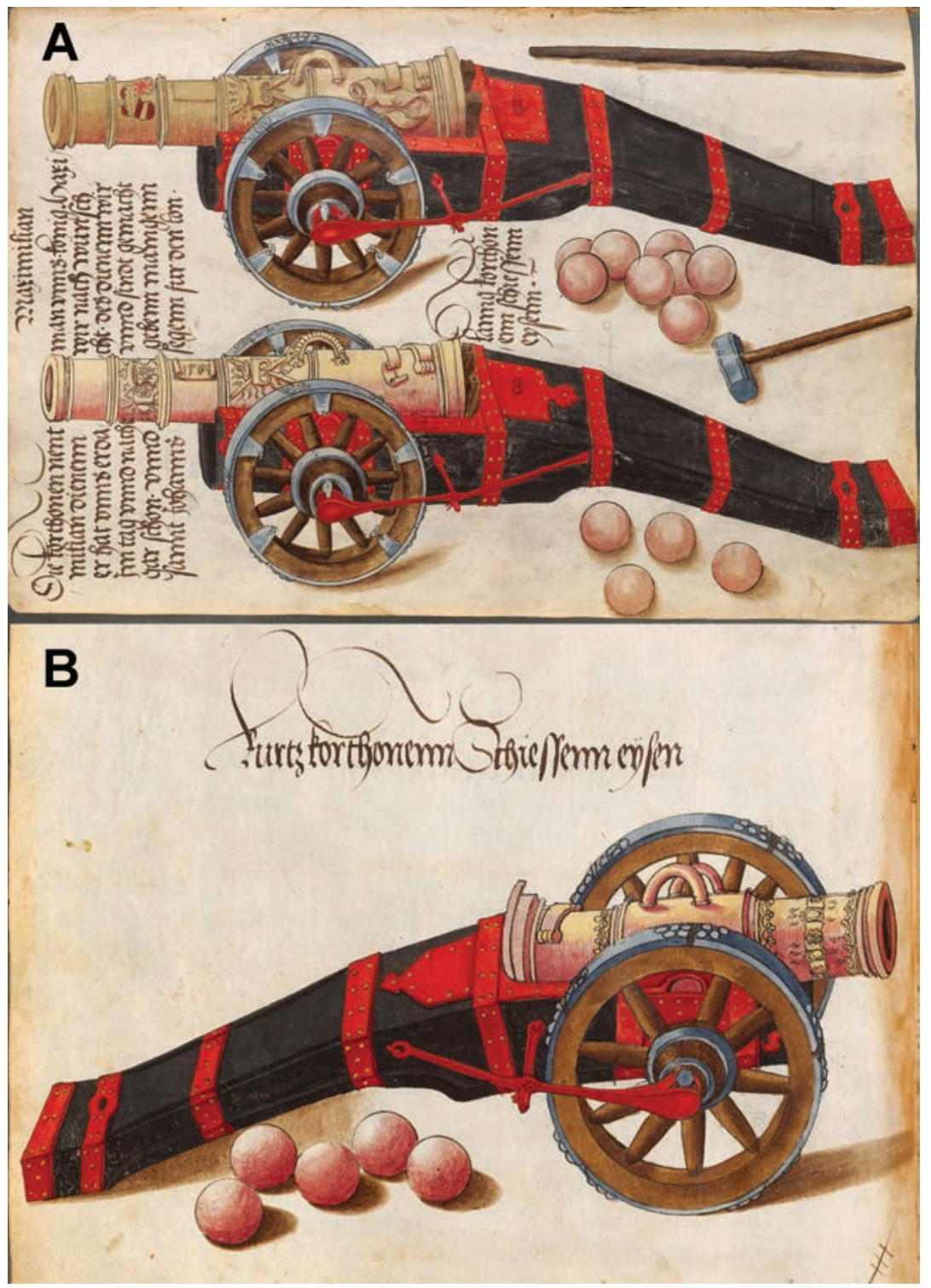

Fig. 21. Carthauns on carriages. There are aiming wedges behind end parts of breeches A - long carthauns. Next to the cannons there are a hammer and a lever. After Zeugbuch (as n. 42), fol. 3 Iv. (c) Bayerische Staatsbibliothek München

B - short carthaun. After Zeugbuch (as n. 42), fol. 37v. (C) Bayerische Staatsbibliothek München 


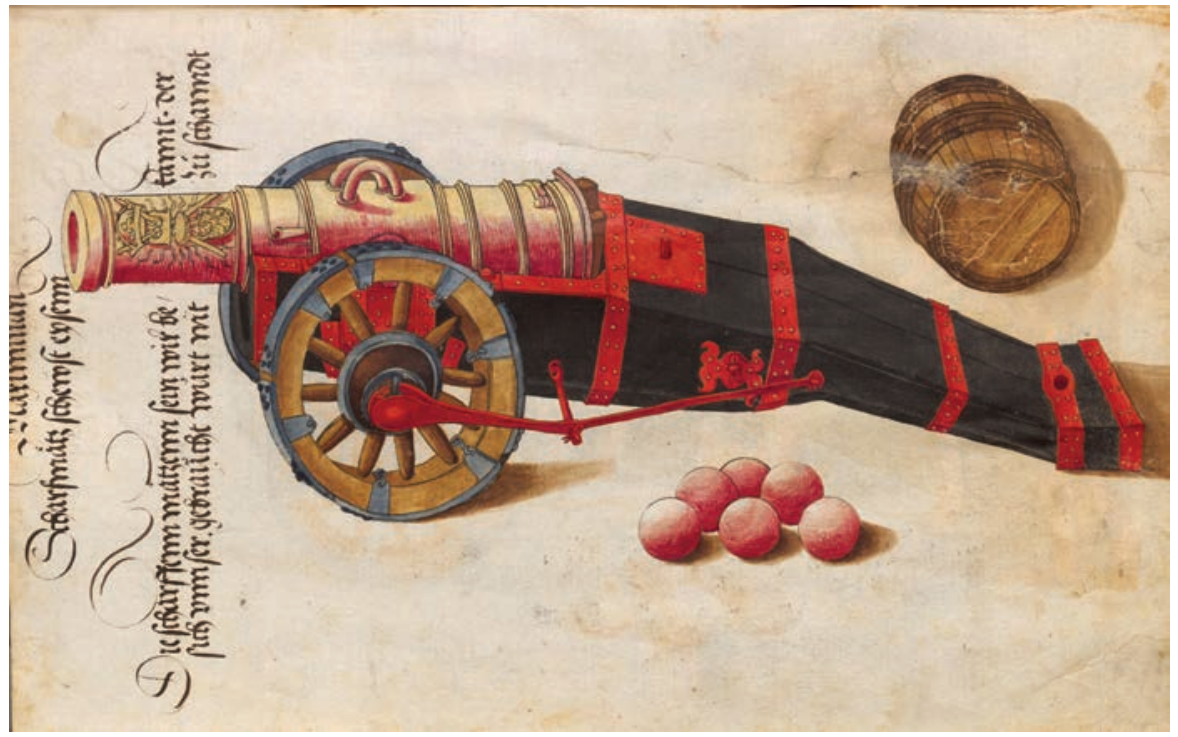

Fig. 22. Scharfen mätzen on the carriage. Aiming wedges and a gunpowder barrel can be seen. After Zeugbuch (as n. 42), fol. 32v. @ Bayerische Staatsbibliothek München

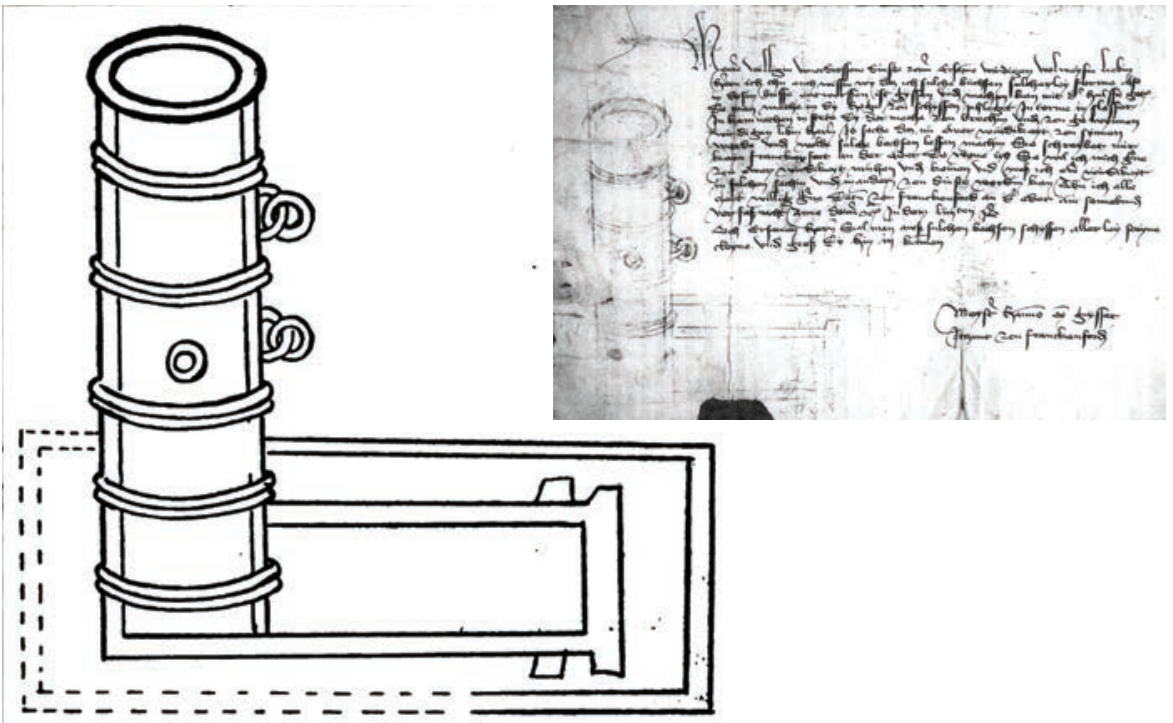

Fig. 23. Gun depiction from the letter of master Hanns to Danzig (Pol. Gdańsk), 1454. The gun seems to be mounted on an immobile stand. After Engel, Waffengeschichte-Studien (as n. 3), p. 118 (see also Szymczak (as n. 19), p. 188, fig. 28; and Możejko (as n. 12), p. 173, fig. 1) 


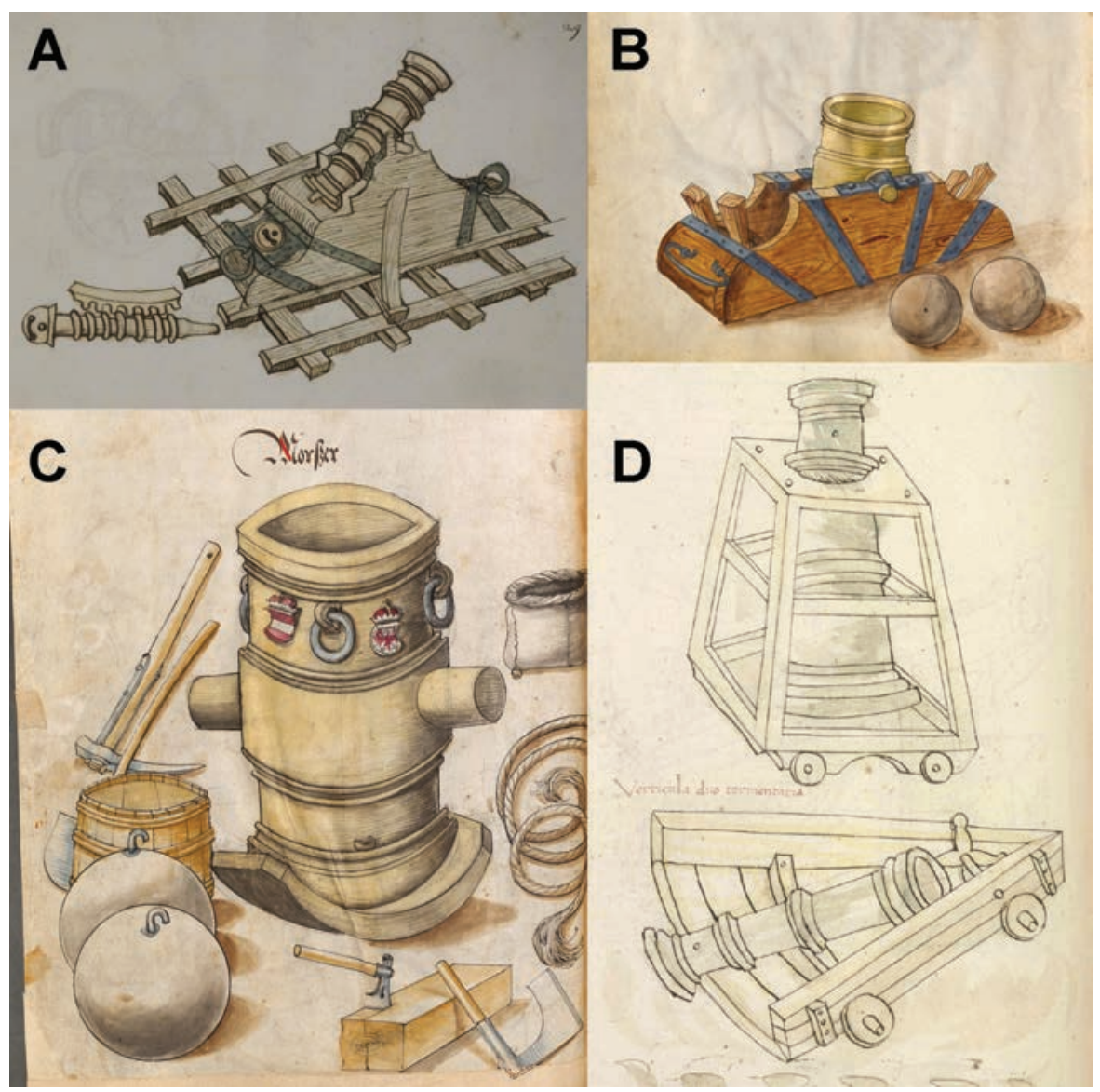

Fig. 24. Mortars

A - mortar on an immobile stand. After Mönch (as n. 4I), fol. 29r. (C) Universitätsbibliothek Heidelberg

B - mortar on an immobile stand. Aiming wedges can be seen. After Zeugbuch (as n. 42), fol. 26v. (C) Bayerische Staatsbibliothek München

$\mathrm{C}$ - mortar: peculiar shaping of the chase end can be seen. It facilitated aiming with the use of aiming wedges. After Zeugbuch (as n. 42), fol. 83v. (C) Bayerische Staatsbibliothek München

D - mortars on carriages. After Valturio (as Fig. I 6), fol. I 26v. Rosenwald Collection, Rare Books and Special Collections Division of the Library of Congress, Washington, DC 


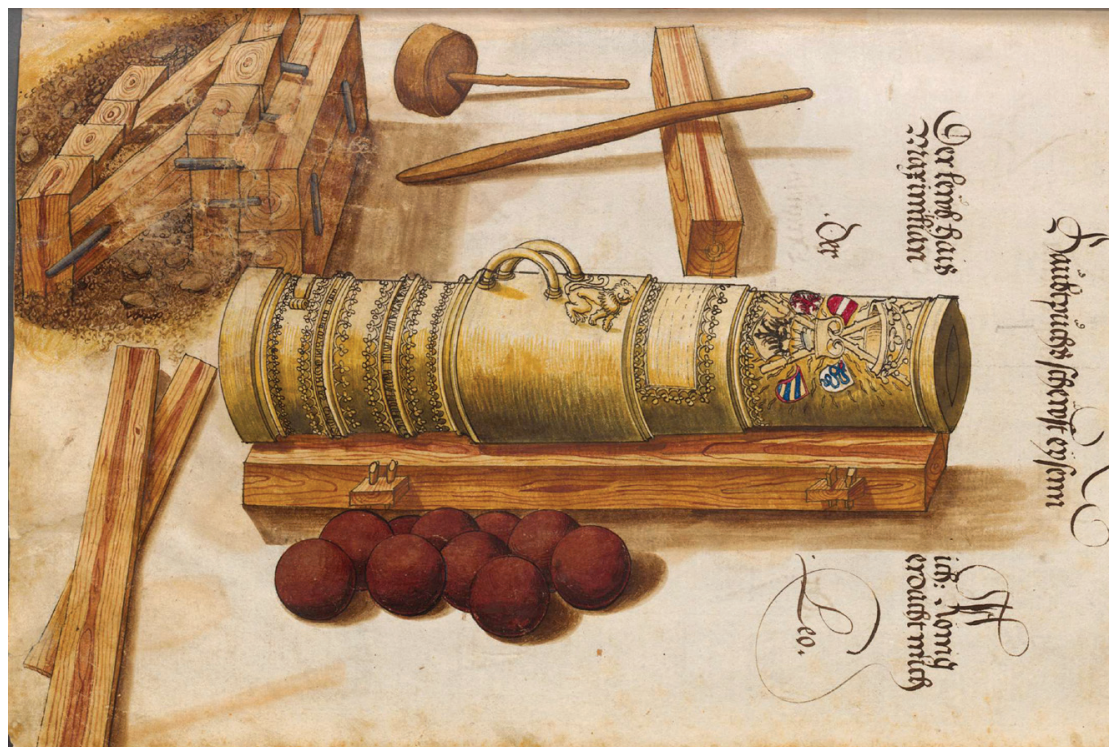

Fig. 25. Heavy cannon (hauptbuchs) on an immobile stand - the Lew (Leo). Attention is drawn to a barrier constructed from massive beams joint with iron braces. It was supposed to absorb the recoil impact when the cannon was fired. A ramrod and a lever can be seen in the background. After Zeugbuch (as n. 42), fol. 36r. () Bayerische Staatsbibliothek München.

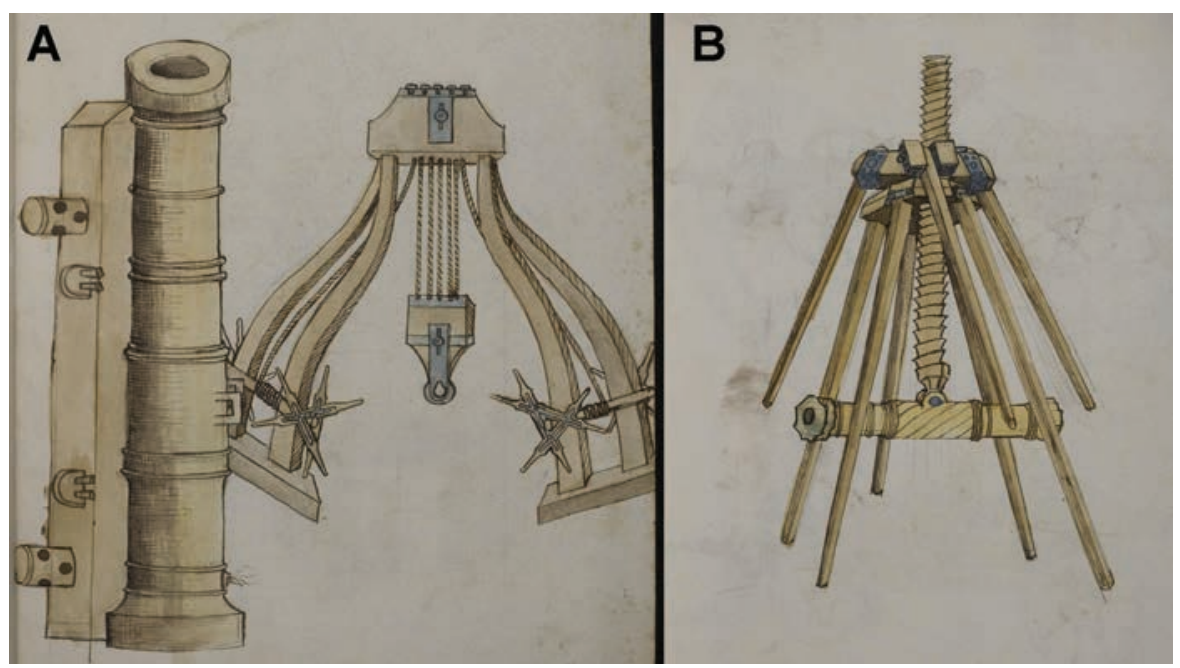

Fig. 26. Cannon cranes

A - after Mönch (as n. 4I), fol. 7r. (C) Universitätsbibliothek Heidelberg

B - after Mönch (as n. 4I), fol. 22r. (C) Universitätsbibliothek Heidelberg 


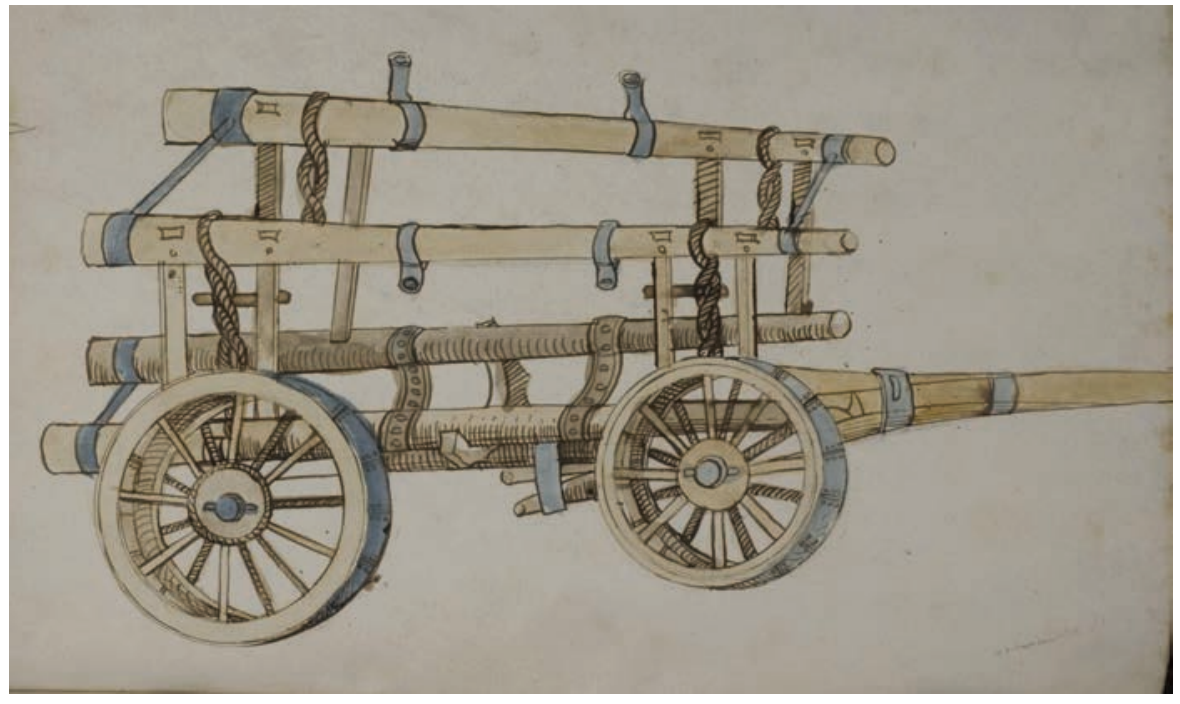

Fig. 27. Wagon for heavy gun transport. After Mönch (as n. 41), fol. 6v. () Universitätsbibliothek Heidelberg 

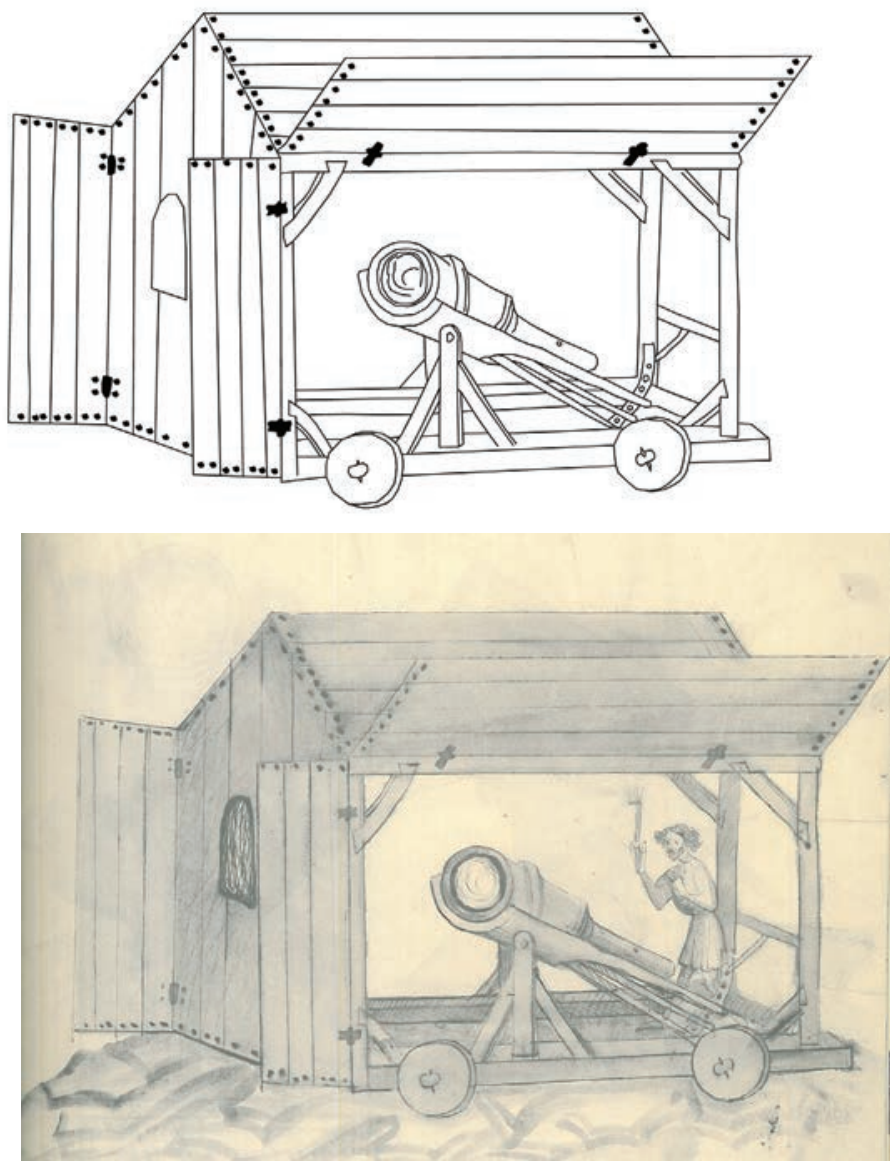

Fig. 28. Cannon in a wheeled shutter. After Kyeser (as n. 39), fol. 108r. Afterdrawing G. Żabiński

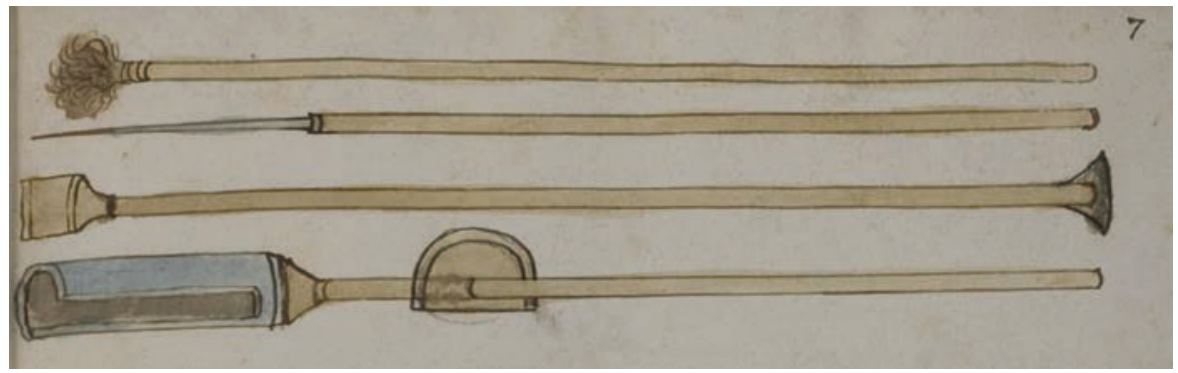

Fig. 29. Artillery equipment - a bore brush, a linstock (?), a ramrod and a charging ladle. After Mönch (as n. 41), fol. 7r. @ Universitätsbibliothek Heidelberg 

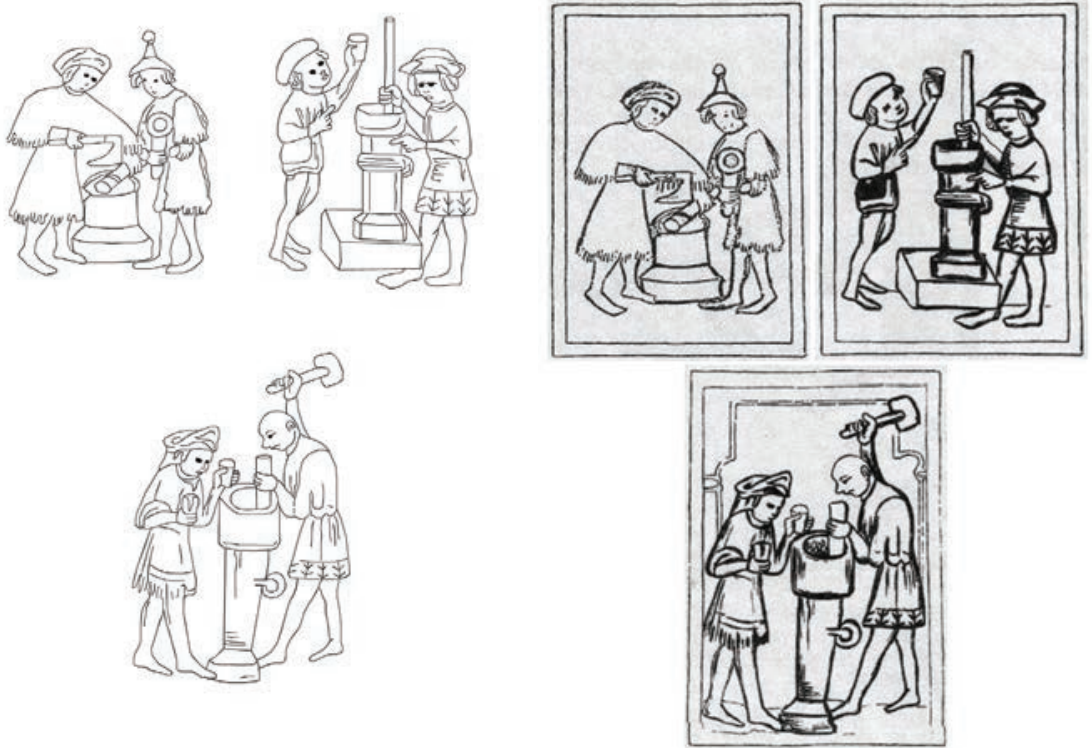

Fig. 30. Stoppers and wedges for fastening projectiles. Codex germanicus monacensis 600, c. 1350, Bayerische Staatsbibliothek, München, Cgm 600, after Schmidtchen (as n. 6), pp. 15-17, figs. 4-6. Afterdrawing G. Żabiński

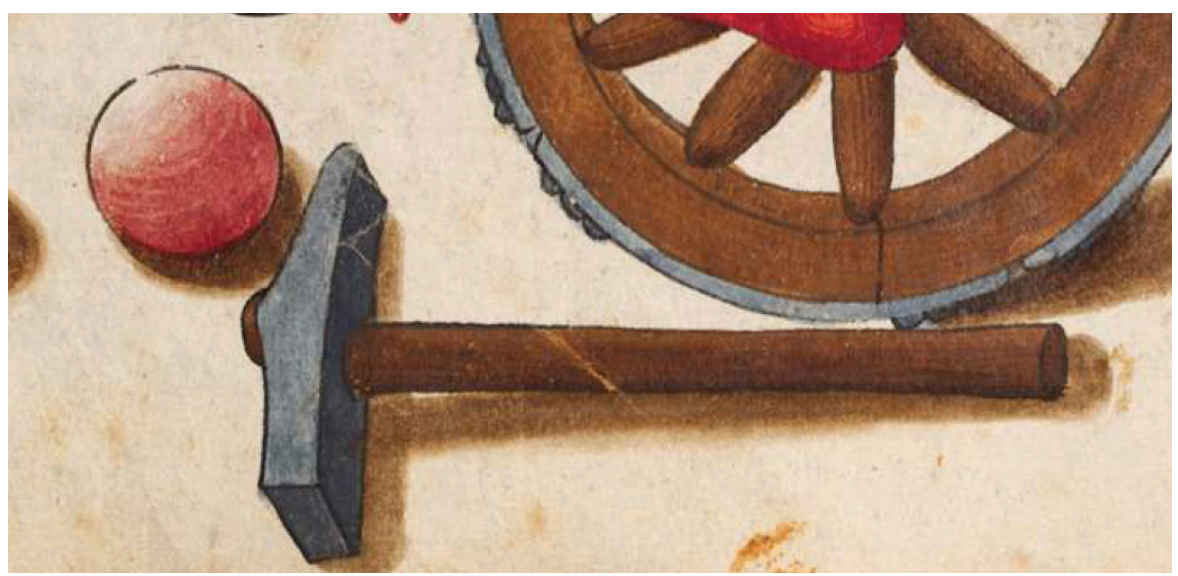

Fig. 31. Hammer next to a short carthaun. After Zeugbuch (as n. 42), fol. 38v. @ Bayerische Staatsbibliothek München 


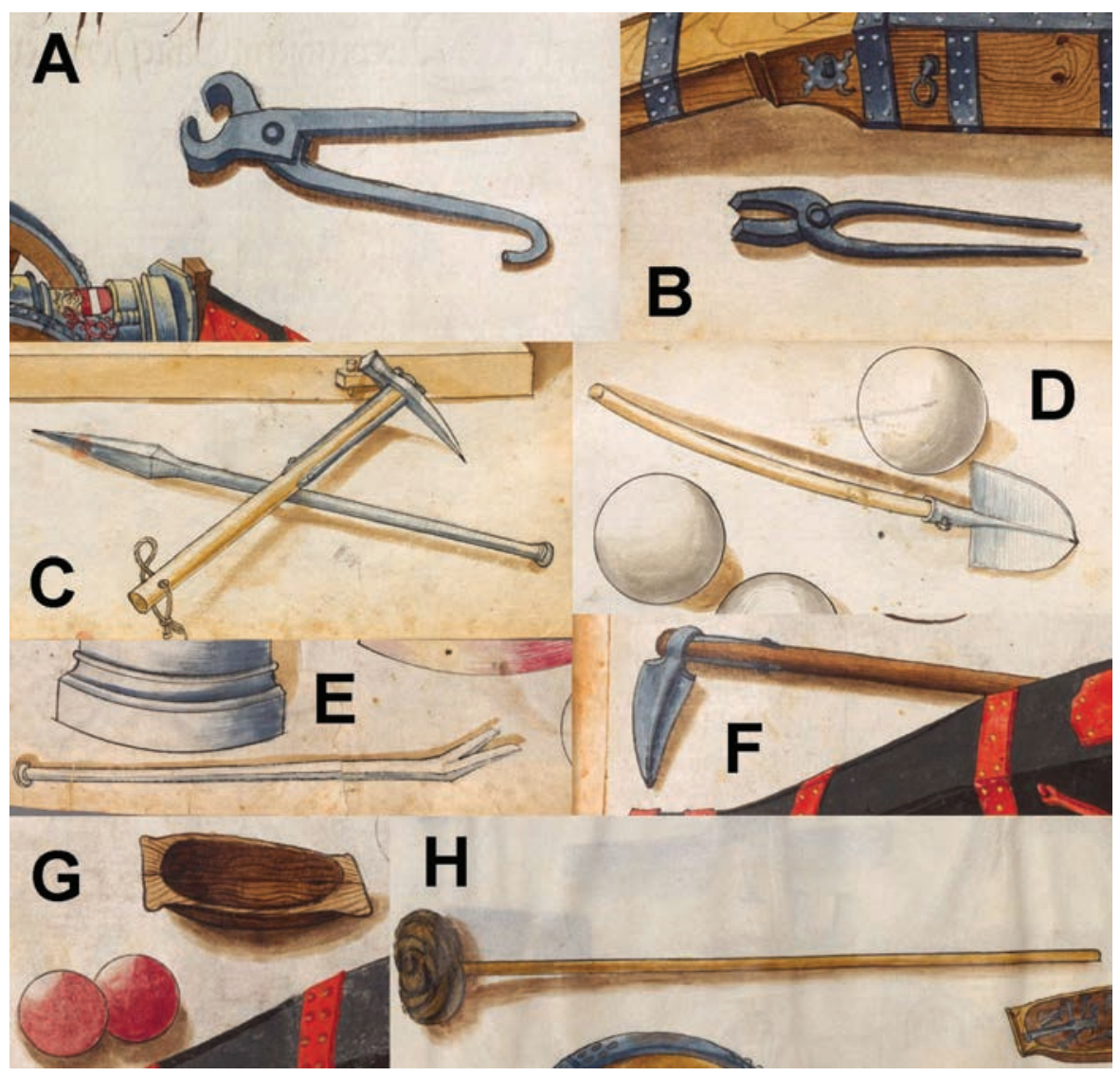

Fig. 32. Other tools associated with firearms

A - iron pincers. After Zeugbuch (as n. 42), fol. 35v. (C) Bayerische Staatsbibliothek München B - iron pliers. After Zeugbuch (as n. 42), fol. 5 I r. @ Bayerische Staatsbibliothek München

C - pick and punch. After Zeugbuch (as n. 42), fol. 79v. @ Bayerische Staatsbibliothek München

D - spade. After Zeugbuch (as n. 42), fol. 79v. (C) Bayerische Staatsbibliothek München E - iron lever. After Zeugbuch (as n. 42), fol. 83r. () Bayerische Staatsbibliothek München

F - mattock. After Zeugbuch (as n. 42), fol. 38r. (C) Bayerische Staatsbibliothek München

G - trough for carrying cannonballs. After Zeugbuch (as n. 42), fol. 4or. @ Bayerische Staatsbibliothek München

$\mathrm{H}$ - bore brush. After Zeugbuch (as n. 42), fol. I 7r. ( Bayerische Staatsbibliothek München 
[245]

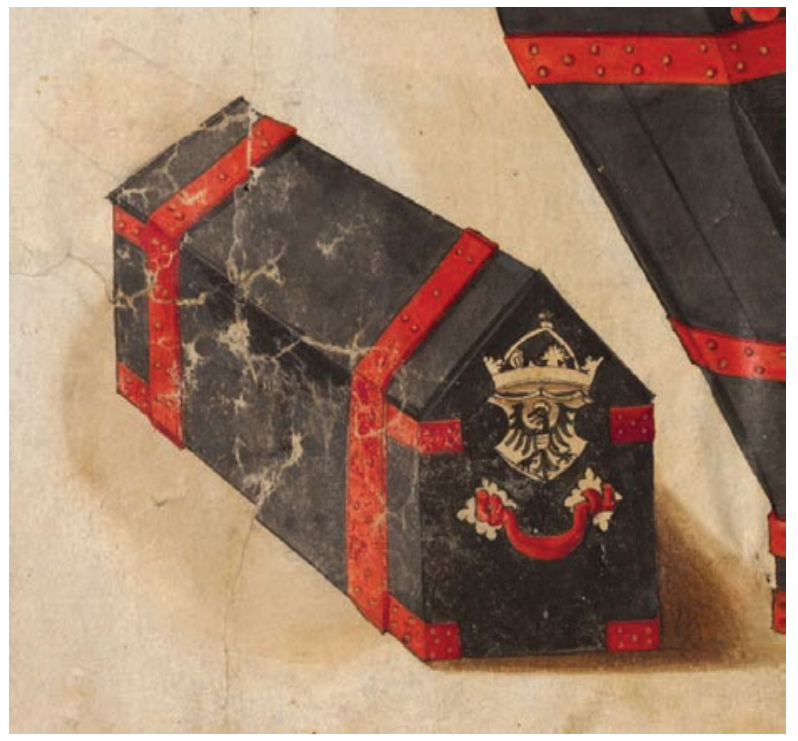

Fig. 33. Artillery chest. After Zeugbuch (as n. 42), fol. 2r. @ Bayerische Staatsbibliothek München 


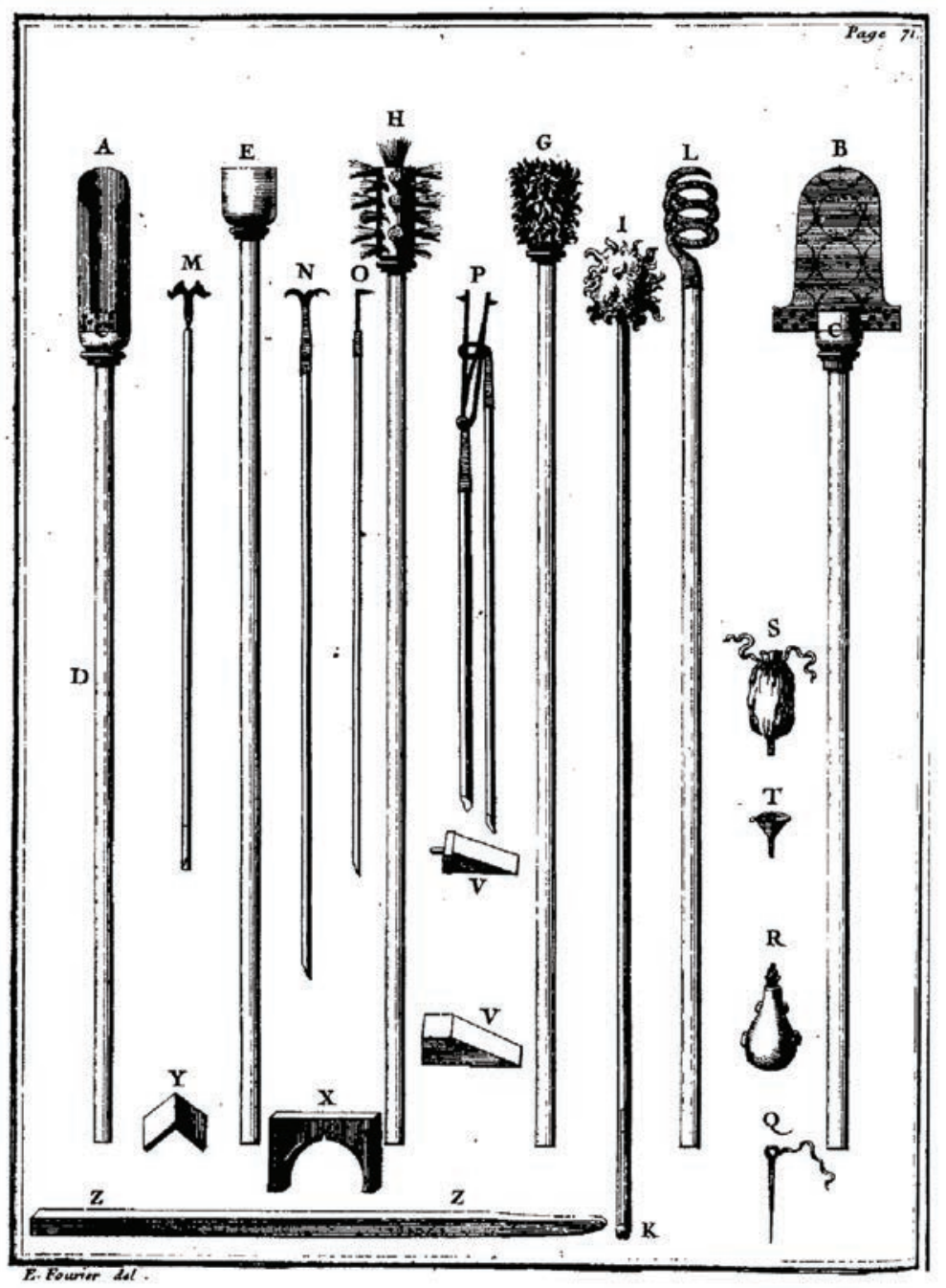

Fig. 34. Artillery equipment, late 17 th century. After Saint Remy (as n. 43), p. 71

A-D - charging ladles and their parts; E-F - ramrod; G-K - bore brushes and their parts; L - wad-screw; $\mathrm{M}$ - linstock; N-P - chat; $\mathrm{Q}$ - priming iron; $\mathrm{R}$ - primer; $S$ - sack for ignition powder; $\mathrm{T}$ - funnel for ignition powder; $\mathrm{V}$ - pointing wedge; $\mathrm{X}$ - pointing fronton; $\mathrm{Y}$ - apron; $\mathrm{Z}$ - lever. 

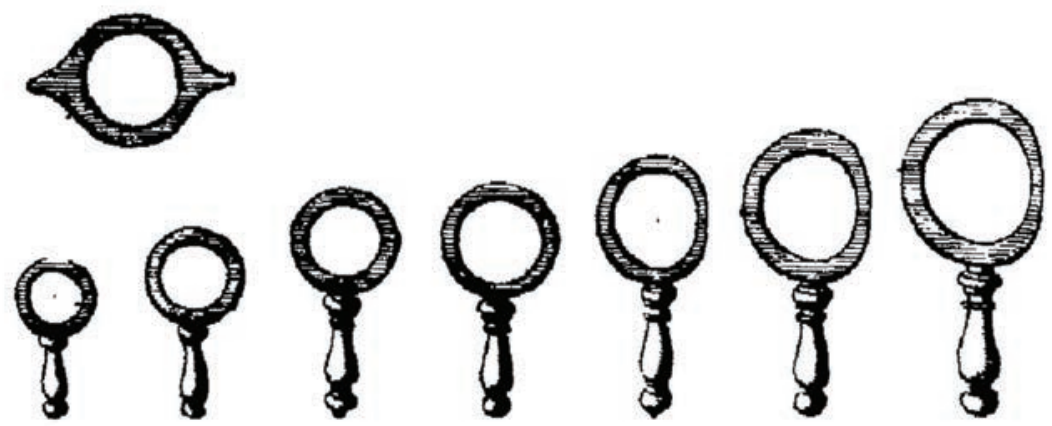

Fig. 35. Passe-boulets or passe-balles. After Saint Remy (as n. 43), pp. 82-83

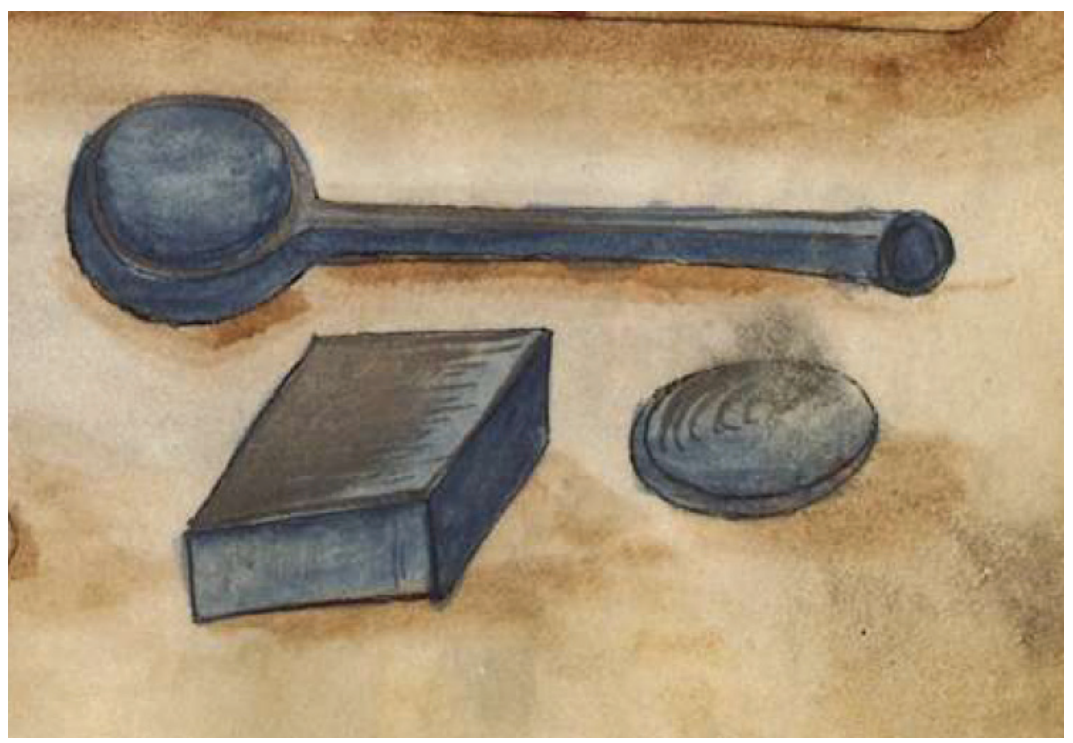

Fig. 36. Ladle for casting projectiles (?). After Zeugbuch c. 1502 (as n. 42), fol. 25r. () Bayerische Staatsbibliothek München 


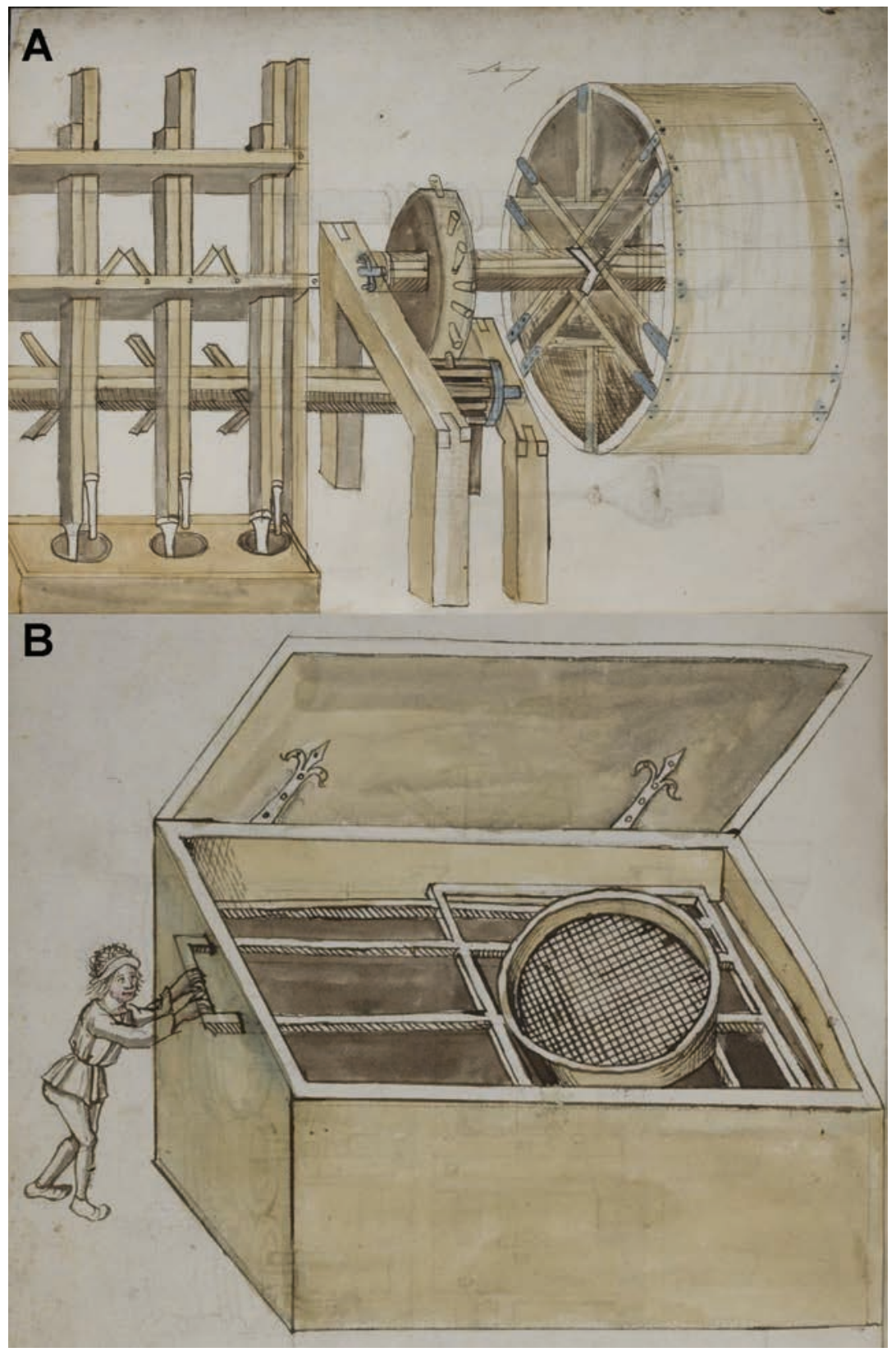

Fig. 37. Tools for gunpowder manufacture

A - device for gunpowder pounding. After Mönch (as n. 4I), fol. 4r. () Universitätsbibliothek Heidelberg

B - sieve. After Mönch (as n. 4I), fol. 3v. @ Universitätsbibliothek Heidelberg 


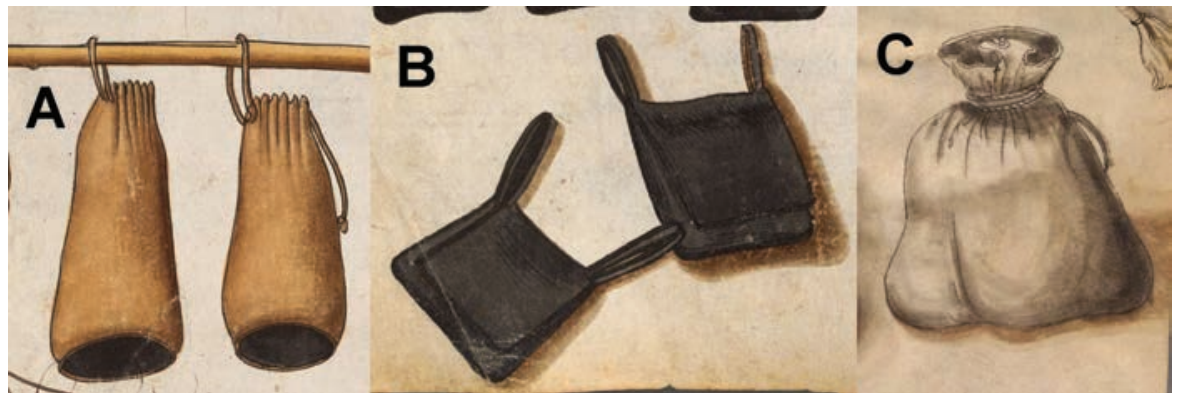

Fig. 38. Sacks and bags

A - leather sacks for gunpowder. After Zeugbuch (as n. 42), fol. 7ov. () Bayerische Staatsbibliothek München

B - leather bags for gunpowder. After Zeugbuch (as n. 42), fol. 70v. () Bayerische Staatsbibliothek München

C - linen sack. After Zeugbuch (as n. 42), fol. 48r. ๑ Bayerische Staatsbibliothek München 